\title{
Educational technology and the construction of authentic learning environments
}

Andreja Istenič

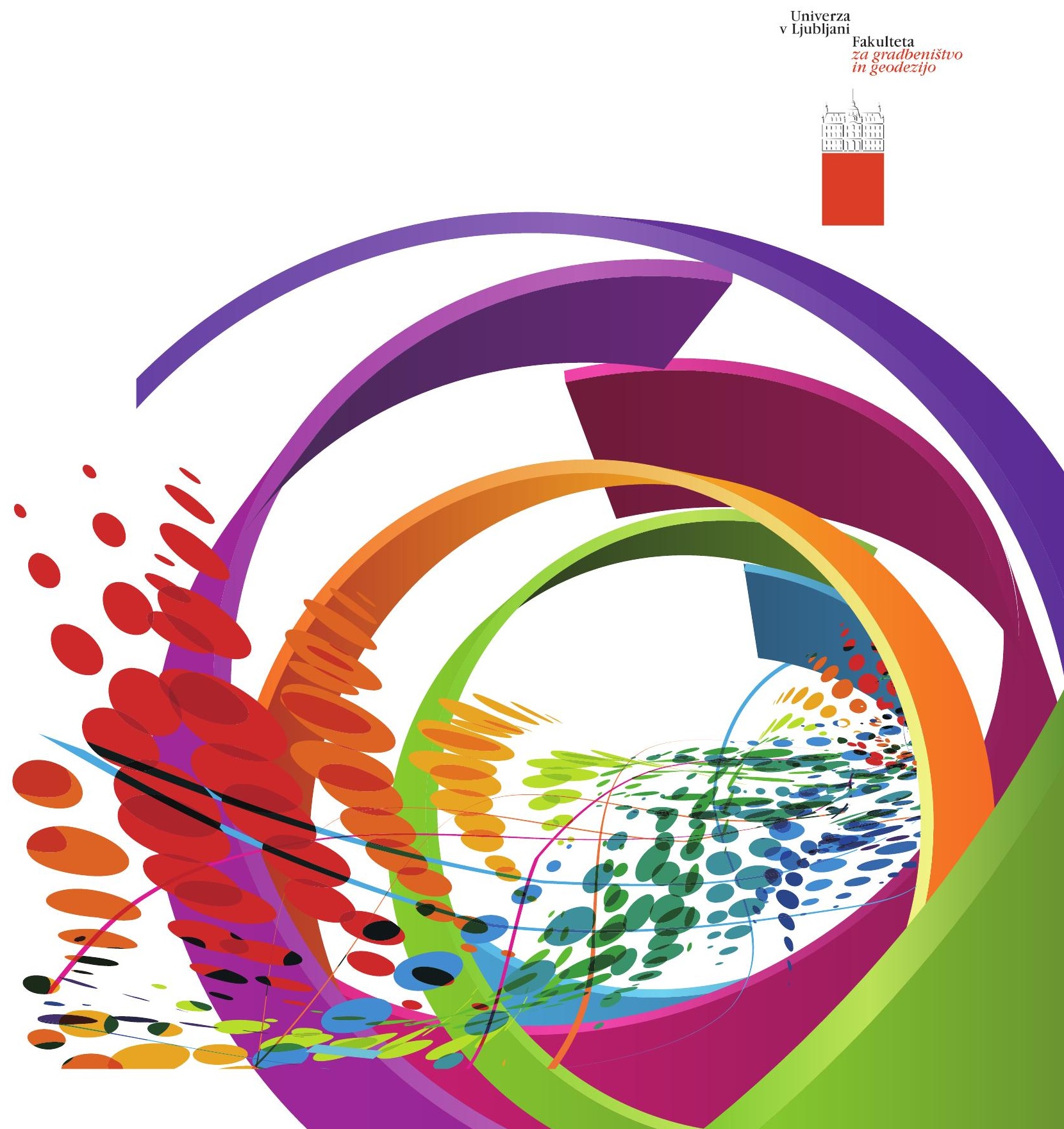


Andreja Istenič

Educational technology and the construction of authentic learning environments

Scientific monograph: 1st edition

The original first published in Slovene language in 2020

Author Andreja Istenič Starčič

The title of the original: Izobraževalna tehnologija in izgradnja avtentičnega učnega okolja

Znanstvena monografija: 1 . izdaja

Reviewers: Martin Kramar and Matjaž Debevc

Translation: Judy Redman

Language editing: Nick Rushby

Design: Denis Starčič

Publisher: Univerza v Ljubljani Fakulteta za gradbeništvo in geodezijo

for a publisher: prof. dr. Matjaž Mikoš

Bibliographic and information processing: Teja Koler Povh

First edition published 2020

Translation published 2021

The publication was co-financed by the Slovene Research Agency (P2-0210). The translation was financed by Slovene Research agency within the call for scientific monographs.

The book is free of cost and is accessible under the licence

CC BY 4.0-NC-ND

This e-book is accessible on the URL: https://repozitorij.uni-lj.si/IzpisGradiva.php?id=125523

DOI: $10.15292 /$ Etcale.2021.01

Kataložni zapis o publikaciji (CIP) pripravili v Narodni in univerzitetni knjižnici v Ljubljani

COBISS.SI-ID 56864771

ISBN 978-961-6884-71-6 (PDF) 


\section{Contents}

Introduction: Educational technology $\quad 1$

Educational technology for the development of the 21st-century skills $\quad 4$

$\begin{array}{ll}\text { The notion of digital and media literacy } & 7\end{array}$

Factors influencing educational technology integration in preschool $\quad 12$

$\begin{array}{ll}\text { Educational technology in the education process } & 18\end{array}$

Educational technology in the global system of factors of education 23

Educational technology in the structure of the education process $\quad 27$

Child's primary environment and digital technology 30

Trends in studying the impact of digital technologies in the child's environment $\quad 30$

Digital technology in a child's play environment 35

Parental mediation in the use of digital technologies $\quad 40$

Teachers and parents working towards partnership $\quad 42$

$\begin{array}{ll}\text { Recommendations and risks } & 48\end{array}$

Educational technology in structuring the educational environment $\quad 52$

Didactic principles $\quad 55$

Genres of play and educational technology

Educational technology in structuring learning objectives

and ergonomic characteristics of its use in learning domains $\quad 62$

Planning and monitoring $\quad 66$

$\begin{array}{ll}\text { Digital storytelling } & 71\end{array}$ 
Storytelling as a teaching method and definition of the concept 71

Studying the characteristics of storytelling and inclusion in the curriculum $\quad 72$

$\begin{array}{ll}\text { Approaches and storytelling designs } & 76\end{array}$

$\begin{array}{ll}\text { Features of digital storytelling } & 77\end{array}$

$\begin{array}{ll}\text { The digital storytelling in teaching evolution } & 79\end{array}$

$\begin{array}{ll}\text { Abstract } & 83\end{array}$

$\begin{array}{ll}\text { Povzetek } & 85\end{array}$

$\begin{array}{lr}\text { Author index } & 87\end{array}$

$\begin{array}{lr}\text { Subject index } & 98\end{array}$

$\begin{array}{ll}\text { References } & 100\end{array}$

$\begin{array}{ll}\text { Review - Martin Kramar } & 117\end{array}$

$\begin{array}{ll}\text { Review - Matjaž Debevc } & 121\end{array}$

$\begin{array}{ll}\text { About the author } & 130\end{array}$ 



\section{Introduction: Educational technology}

In the European continental tradition educational technology is an integral part of didactics (Blažič, Ivanuš Grmek, Kramar and Strmčnik, 2003) as a pedagogical discipline (Strmčnik, 2001). Didactics is defined as a theory 'about education and instruction (1961, pp. 32), where teaching is understood as an educational process' (Strmčnik, 2001, pp. 20 citing Šilih, 1961, pp. 32). Within didactics, educational technology in the process of learning and teaching is connected with pedagogical psychology, pedagogical sociology, philosophy of education, leadership and management in education and other sciences (Blažič et al., 2003). In that development, the field of educational technology has been linked to learning theories and teaching theories and, in the European tradition, to didactic theories. With the development of computer science and information technology, this field is also influenced by computing, artificial intelligence, systems design, human-computer interaction (Issroff and Scanlon, 2002, pp. 4) and other social sciences and humanities that examine technology in society.

In the United States, the field of education has been influenced by the psychology of education with its theories of learning and teaching. These also influenced education technology, which developed as an independent field. Under the influence of cognitivism, which develops teaching models, they also began to consider educational technology together with teaching models developed within the framework of teaching theories. (Reiser, 2001b). Reiser describes two practices covered by educational technology that gave rise to the concept of instructional design and technology in the 1970s: (1) the use of technology and media for instructional purposes, and (2) the use of systematic instructional design procedures (Reiser, 2001a). Designing and evaluating curricula and solving problems in its implementation and improvement is the core of educational technology in the British tradition (Rowntree, 1982).

Educational technology was initially limited to the marginal and supplementary role of aids, devices and resources to present instruction. Influenced by communication theories, it was conceived as a conveyor or mediator of information (Blažič et al., 
2003). Influenced by cognitive theories of learning and teaching, the application of tools was joined by the application of instructional design (Reiser, 2001a). In defining the concept of educational technology, we distinguish two aspects: the use of technology as a technical device and the impact of technology on the design of the learning process. Educational technology derives from two basic assumptions:

- the technical possibilities offered by a technology, and

- how those technical options are used.

The introduction of educational technology solves two basic tasks: enabling the updating of education in accordance with technological progress and the improvement of teaching and learning processes. Technological developments and innovation enable changes in the field of teaching and learning. The development of innovations in the field of educational technology and their acceptance among teachers and students is conditioned by the factors of formal and non-formal learning processes. The ways in which innovations are disseminated and accepted among endusers have changed with the development of information and communication technologies (ICTs), which have enabled new ways of communication. The earlier proliferation of ICT, which characterizes the rapid spread in all social environments and systems, is complemented at a time of social networks and mobile technology by percolation, where the spread of technology infiltrates practices between different environments and systems.

Let us illustrate the conceptual aspect of the use of the term educational technology, which concerns the technological aspect and the aspect of designing learning processes by comparing the use of analog technologies with digital ones. Digital storytelling covers the technological aspects of the production and presentation of a story, as well as all the didactic features of the analog way of traditional storytelling. Therefore, we need to study it both from a technological and didactic point of view. Storytelling in the curriculum is introduced in language and literature, history, art and music education. Digital storytelling at the level of preparation and integration in the learning process combines didactic aspects already established in curriculum areas with new technological possibilities. Technology also brings new possibilities, such as chat rooms, online classrooms and online social networks. Its predecessors were radio and television school lessons, which were characterized by 
remote transmission. The fundamental contribution of today's online social networks is to introduce new possibilities for designing the learning process.

Educational technology initially covered material and physical means in the role of aids, teaching resources and devices. Influenced by communication theories, it was conceived as a conveyor or mediator of information (Blažič et al., 2003). It has long been included in the theory and practical structural components of the educational process (Kramar, 2009). Influenced by cognitive theories of learning and teaching, the treatment of a device was joined by new treatments of instructional design procedures (Reiser, 2001a). Educational technology intertwines two aspects: the aspect of the use of technology as a structural component and the aspect of the design of the learning process (process component).

In the preschool period, we find less intensive use of the term educational technology in the literature. Two facts contribute to this. The preschool curriculum is based on play as a child's primary activity. In the game, the child interacts and uses various digital technologies - artifacts in their immediate environment. In the preschool period, the primary environment is the family and preschool education in kindergarten takes place in close partnership with parents. In the field of early learning, the use of digital technology is widely found in the literature, covering a wide range of digital devices, contents, games and toys that children use in the home and kindergarten environment, while in the curriculum we find the use of information and communication technology. Another important fact is the definition of children's play and its functions. Children's play is an autotelic activity with the final objective within itself, which the child plays for the sake of the game itself and learns and develops during the game. According to the findings of a survey conducted between parents and teachers by Plowman, McPake in Stephen (2010; 2012), digital technology contributes to learning and development in three main ways. It: (1) develops skills for understanding the functionality and interactivity of digital media as well as the ability to manipulate them; (2) expands knowledge and understanding of the world in various curricular areas through the use of programs, websites and digital books; and (3) develops dispositions for learning in the affective, social and cognitive domains. (Plowman, McPake and Stephen, 2012). 


\section{Educational technology for the development of the 21st-century skills}

Among the key skills competencies for the 21st century, three sets of skills and competencies are important. The first set consists of skills for life and career. Within the second the $4 \mathrm{C}$ set of skills for learning and innovation involves Creativity, Critical thinking, Communication and Collaboration. The third set includes information, media and technological skills (P21 2010; 2012). Trilling and Fadel (2009) define the $7 \mathrm{C}$ set of skills for the 21 st century as consisting of Critical thinking and problem solving, Creativity and innovation, Cross-cultural understanding, Communications, information and media literacy, Computing and ICT literacy, Career and learning self-reliance. Merriam-Webster dictionary (Merriam-Webster's Collegiate Dictionary, 2020) defines skill as '(1) the ability to use one's knowledge effectively and readily in execution or performance; dexterity or coordination especially in the execution of learned physical tasks; (2) a learnt power of doing something competently: a developed aptitude or ability. 'Among synonyms listed are artistry, masterfulness, artifice, cleverness, and craft. Competency is defined as '(1) possession of sufficient knowledge or skill; legal authority, ability, or admissibility; and (2) as a specific area of competency.' Among the synonyms for competency are capability, ability, and faculty (Merriam-Webster's Collegiate Dictionary, 2020).

In contemporary life and work, both formal and informal learning are essential and theories examine cultural contexts of authentic practices which should become part of formal learning. There is the notion of technology skills a person possesses in her social practices while not applying them within her professional competency area. Building a professional competency is a complex process involving a diverse set of skills, knowledge and competences. Developing a child's literacy depends on incentives in the child's proximal environment and formal instruction. Diverse national and cultural contexts define skills, knowledge and competences within curriculum areas and increasingly computer technology skills are identified as basic skills for everyone and included within population literacy competency or standards. 
Educational technology integrates all skills and competences areas defined within P21 (P21 2010; 2012):

- information, media and technological competencies;

- the use of different tools for communication and collaboration, critical thinking and creativity, which affect competences for learning and innovation;

- establishing a learning environment for the development of competences for life and work.

Information, media and technological competences can be considered in the framework of various forms of literacy. For example, UNESCO has defined media and information literacy for teachers by including components of information, media, computer, internet, digital and media literacy (Wilson, Grizzle, Tuazon, Akyempong and Cheung, 2013).

Computer thinking was defined by Janette Wing in 2006 as problem-solving, systems design, and understanding of human behaviour based on basic computer concepts (Wing, 2006). The author encouraged the inclusion of computer thinking in the curriculum of compulsory education of the entire population (Barr, Harrison and Conery, 2011). In his pioneering work Mindstorms, Seymour Papert (1980) based on Piaget (1962) developmental theories substantiate computer thinking and its contribution to the development of problem-solving skills. Barr and co-authors define computation thinking as a problem-solving process that includes problem formulation supported by the use of computers and other tools, data organization and analysis, data representation with models and simulations, algorithmic thinking, and identifying, analyzing, generalization and transfer of the problem-solving process to various fields (Barr, Harrison and Conery, 2011). Computer programming involves knowledge of computer concepts, practices, and perspectives that help students understand themselves, society, and technology (Wing, 2008; Lye and Koh, 2014). It encourages the development of the ability, dispositions and attitudes to perform complex tasks, perseverance in difficult tasks, tolerance for unclear tasks, the ability to solve problems with an open solution, and the ability to communicate and cooperate in achieving goals (Barr, Harrison and Conery, 2011). 
In the second set of learning and innovation competencies is the $4 \mathrm{C}$ model that is similar to the taxonomy of educational technology given by Bruce and Levin (1997) based on Dewey's (1943) model of children's impulses to learn in interaction with the environment. The taxonomy encompasses four types of educational technology, namely: (1) learning by inquiry, (2) interaction and communication as basic for social engagement, (3) construction in play and creativity involving a set of materials and (4) expression (ibid).

The beginnings of educational technology were marked by audiovisual communication and the use of devices for presentation of learning content as a teacher's aid. Instructional radio and television were delivering instruction and transmitting the learning content while lacking any interactive component. Computer-assisted teaching and intelligent tutoring systems establishing interactive learning environment were initially targeted at the individual learner. Computer-assisted collaborative learning expanded in the 1990s, with the development of the Internet (Stahl, Koschmann and Suthers, 2006) and under the influence of constructivism to promote student-centered learning (Means and Olson, 1997). The use of the computer in learning has transcended a purely individual orientation. Computer-assisted collaborative learning combines the advantages of a group form of learning, in an interaction triangle of learning (content - student - student) using a variety of collaborative technologies, learning resources and teaching methods. Group learning implements the principle of individualization while exploiting influences in the social-affective learning domain, in an interaction between students (Strmčnik, 1987). Learning takes place in social interaction and in interaction with cultural artifacts in the socio-cultural environment (Vygotsky, 1987). Collaborative learning defines the interdependence of students in achieving the goals of all individuals and groups (Johnson and Johnson, 1996) and shared cognition and learning (Resnick, 1993).

Computer-assisted collaborative learning is currently still a basic educational technology (Adams Becker, Cummins, Davis, Freeman, Hall Giesinger in Ananthanarayanan, 2017) as well as a basic strategy in educating teachers to use educational technology (Hattie, 2009; Tondeur, van Braak, Siddiq and Scherer, 2016; Hao and Lee, 2017). Computer-assisted learning environments encourage creativity and critical thinking (Istenič Starčič and Lebeničnik, 2020). Research in the last decade of 
the 20th century shows the useful contribution of computer technology in the early childhood education setting in all curricular areas and also its impact on the development of the child and her abilities of creative and critical thinking, on the social development and learning to learn (Clements, Nastasi and Swaminathan, 1993; Clements, 1999; Yelland, 2005).

\section{The notion of digital and media literacy}

Street identifies four traditions in defining the developmental aspects of literacy and pedagogical approaches to literacy: literacy and learning; cognitive approach to literacy; an approach that addresses literacy embedded in social practices; and literacy as text (Street, 2005). In teaching and learning literacy, he pointed out the transition from the notion of literacy in the context of cognitive processes to socio-cultural understandings of literacy. In the context of a cognitive approach, literacy is understood as an independent entity that is taught independently of contexts, as neutral for use in different contexts. In contrast, socio-cultural understanding places literacy in the authentic contexts of various socio-cultural practices. Within this approach literacy is conceived as socially defined and not independent of power relations in society, which is characteristic of the "autonomous model" within the cognitive approach. The autonomous model understands literacy as a type of skills, tools, techniques and cognitive competencies that the individual learns and will enable her to work in different contexts. (Street, 1989; 2005).

Earlier, Vygotsky (1978) placed the pedagogical interventions of teaching and learning literacy in socio-cultural contexts, where literacy develops in authentic practices. With the Berners-Lee concept of the World Wide Web and the intensive proliferation and growth of various online services, the expansion of socio-cultural practices on the Internet began at the end of the last century. With the rise of digital content on the Internet, the definition of literacy has expanded beyond embracing the abilities of reading and writing, to (1) creating and understanding content in a variety of representational ways, including (2) a level of codification with operational and technical competencies and (3) an epistemic level content interaction with content that takes place in socio-cultural practices. 
In a period of intensive development of various technologies and media, the nature of communication and the notion of literacy which were traditionally tied to the use of the medium of writing, has changed (Buckingham, 2015) beyond the original notion tied to the use of the medium of writing. Literacy is seen as emerging literacy that develops in children's play with the media (Spencer, 1986, In Buckingham, 2015), visual literacy (Moore and Dwyer, 1994, In Buckingham, 2015), television literacy (Buckingham, 1993, In Buckingham, 2015), information literacy (Bruce and Levin, 1997, In Buckingham, 2015).

Literacy is not an autonomous entity (Street, 1989; 2015), it is characterized by a variety of phenomena (Buckingham, 2015) in different socio-cultural and technological conditions and requires modern pedagogical approaches (Cope and Kalantzis, 2000). Marsh and colleagues define literacy as digital literacy, as it no longer concerns only writing and takes place using a range of digital technologies at events and practices that include both online and offline activities (Sefton-Green, Marsh, Erstad and Flewitt, 2016; Marsh, Hannon, Lewis and Ritchie, 2017).

Educational technology is related to the third set of competencies for the 21st century, which includes information, media and technological competencies (P21 2010; 2012). Information, media and technological competences are addressed in the context of information, media and digital literacy. Conceived on the basis of the concept of autonomous literacy, as defined by Street (1989), they gradually included several dimensions and also intertwined and complemented each other. The more recent Dutch definition of digital literacy links ICT skills, media literacy, information literacy and computer thinking and is implemented in the national curriculum integrated with authentic learning and assessment (Fisser, Heitink and Strijker, 2020). Literacy and literacy development require a socio-cultural context and a place in which meaning is constructed (Street, 2005).

Definitions of information literacy in the 1970s included searching for and obtaining information resources, solving problems, and using information in a variety of situations. In the 1980s, with the expansion of the computer technology, a variety of sources and different technologies that enable information retrieval and the importance of critical evaluation of information were highlighted. In the 1990s, the 
definition, which includes the search, critical evaluation and use of information, became stable. During this time, there have been strong movements for the integration of various information sources into education and the development of information literacy, which enables quality learning with diverse resources. These activities resulted in the requirements for the inclusion of information literacy among the key components of literacy (Behrens, 1994).

Media literacy was defined in the 1990s as a critical reading of information and media content and includes the post-print media (Bawden, 2001). Bawden (ibid.) conceives of media literacy as overlapping information literacy and, above all, with one of its definitions given by Hamelink (1976, cited in Bawden, 2011). This differs significantly from other definitions as Hamelink (ibid.) defined information literacy as the ability for individual and independent opinion and assessment of media content and the need for the media to be liberated from political and economic influences. Hobbs (1999) summarizes key issues of media literacy as early as the late 1990s, including (1) the role of media literacy for child safety, which the child develops through active participation in media debates; (2) the child's role as a producer and not just a consumer, which is also reflected in the learning activities of media content production; (3) the role of popular culture in the development of media literacy as a culturally located practice; (4) the ideology of the media literacy curriculum; (5) equality in ensuring media literacy for all children; and (6) the role of media organizations in literacy development and hidden curriculum.

These definitions are aligned with the socio-cultural understanding of literacy as defined by Street (2005). The findings of media studies, sociology, psychology, pedagogy, health care, librarianship and information studies are important in the research and development of media literacy as a multidimensional concept. For media literacy, treatment in different contexts is essential: in the context of a critical citizen and user of media content, in the context of child development, the impact of media content on socialization processes and in the context of professional work increasingly involving the Internet and computer tools (Hobbs, 2017). Among digital literacy skills, Hobbs (2011) lists technical, cognitive, media, and social skills. Also, according to Potter (1998) media literacy is multidimensional and encompasses the cognitive, emotional, aesthetic and moral dimensions. The definition of media liter- 
acy from the year 1992 highlights a critical reading of media and media content based on five points: media are constructed by and construct reality, media have market, political and economic effects, the media form and content are linked to aesthetic and communicative code, and the media message is interpreted by the reader (Aufderheide, 1992).

Digital literacy emerged in the 1990s (Bawden, 2001). In 1997, Gilster defined digital literacy as the skill of using the Internet, which, compared to print media, presents content in supertext and in various forms, and information literacy through critical reading of information. He identified four competencies: knowledge acquisition, content evaluation, Internet search, and supertext navigation (Gilster, 1997). The epistemic and representational dimensions are present in Glister's definition.

Current treatment of digital literacy includes two submenus: (1) conceptualization of digital literacy in the process of moving from the technological and information aspect to social practices and (2) transformation of original literacy with the medium of writing, which is transformed into multicode literacy and multidimensional literacy; that is compound literacy in social practices.

We follow the conceptualization of digital literacy as a literacy that transforms the understanding of the media as technological or informational (Buckingham, 2015) into an understanding of the media as a social practice (Sefton-Green, Marsh, Erstad and Flewitt, 2016). The definition of information literacy highlights the critical evaluation and use of collected information through the development of the information society (Behrens, 1994). The technological definition of computer literacy (Fetler, 1985), which means the technical use of computer technology and its application, has led in the curriculum to the development of technological concepts, skills of using technology, programming, computer thinking and problem solving. Langhorne, Donham, Gross and Rehmke (1989) extend and define the concept of computer literacy with three components: computer knowledge, application usage (text editor, databases, spreadsheets, graphics, desktop publishing, music, computer-assisted learning), and knowledge of the social context associated with 
computer use (copyright, right to privacy, the impact of technology on future life, awareness of the information society).

The development of digital technology enables, in addition to the consumption of media content, also the production (Jenkins, Clinton, Purushothm, Robinson and Weigel, 2007) and influences modern literacy, which no longer takes place solely through the use of traditional writing media (Buckingham, 2015). Emerging practices in socio-cultural contexts that take advantage of the nature of digital technology allow for multimodal text formatting and multimodal literacy (Kress and van Leuween, 2001; Kress and Jewitt, 2003). Literacy, in conjunction with reading and writing practices, no longer concerns only writing, but involves multimodal expression (Marsh et al., 2017). The definition of multimodal literacy refers to media and semiotic means, according to this definition representation and communication are multimodal (Kress, 2003). Computer technology enables multimodal representations and communications (Debevc, Weiss, Šorgo and Kožuh, 2020) and thus influences thinking (Kress and Jewitt, 2003).

The literacy as dynamic is dependent on the respective socio-cultural context. Multidimensional or compound literacy, which is constantly alive and changing in the socio-cultural contexts of users using dynamic representational resources, embraces the various socio-cultural practices of users in their authentic contexts (New London Group, 2000). Technological development enables the emergence of new forms of texts that in different ways constitute distinct forms of literacy (e.g., wordof-mouth, textual, visual, digital, multimedia) and enable different ways of interaction and collaboration (Grosman, 2011).

Marsh, Hannon, Lewis and Ritchie (2017) explore literacy as a practice of reading and writing, using a variety of digital technologies that support different modalities, rather than just writing. Sefton-Green, Marsh, Erstad and Flewitt (2016) define digital literacy as reading, writing, and reasoning practices using a range of digital technologies that take place at events and practices that include both online and offline activities. Digital literacy crosses physical boundaries and the boundaries of online / offline and establishes complex communication beyond time and space (Lander and Sheehy, 2004). Digital literacy encompasses digital text creation, and 
the development of text creation skills takes place in a variety of socio-cultural practices (Lankshear and Knobel, 2008; 2011).

The pedagogy of multidimensional or compound literacy defines literacy as embedded in socio-cultural practices co-established by the Internet and digital practices (New London Group, 2000). Along with school literacy, it becomes important to re-learn literacy practices that develop outside the school context, for example at home and in peer groups, and to include them in the school curriculum (Lankshear in Knobel, 2008; Lankshear and Knobel, 2011). A child's emerging literacy in a family environment interacts with a variety of Internet sources (Plowman, Stephen and McPake, 2010a).

The use of digital resources for reading and creating electronic texts with spatial orientation and a high level of composition (verbal, visual and other data), transforms the reader's / writer's linear interaction with text and conditions literacy, speech-language development and education (Grosman, 2011). With a more complex conception of literacy in the formal learning environment, the need for teaching and learning literacy is substantiated, which includes all forms of reading and composing texts, in connecting various formal and informal social practices (Grosman, 2011).

\section{Factors influencing educational technology integration in preschool}

At the preschool level, the important factors influencing educational technology integration are digital literacy skills (Hatzigianni and Kalaitzidis, 2018). The readiness of teachers to use of their digital literacy skills in teaching and building their educational technology competences depends on their perceptions and attitudes of the contribution of educational technology in early learning in relation to their pedagogical beliefs (Istenič Starčič and Lebeničnik, 2020; Hatzigianni and Kalaitzidis, 2018). Perceptions and beliefs are the strong influencing factor and predictors of educational technology integration (Ertmer, Ottenbreit-Leftwich, Sadik and Sendurur, 2012). Developing digital literacy with the potential for educational technology competency and the formation of underpinning pedagogical beliefs is signifi- 
cantly influenced by the initial teacher education (Drent and Meelissan, 2008) which informs attitudes guiding technology integration in preschool classroom.

Researchers examine readiness to use new technology by measuring an interaction between person's perception of the usability of the technology or how much technology can improve an individual's performance in the context of person's technology related attitudes and behavioural intention (Davis, 1989; Venkatesh, Morris, Davis and Davis, 2003). This research approach is needed for examining teacher's readiness for innovation in lesson planning and performance (Valenčič Zuljaand Marentič Požarnik, 2014; Istenič Starčič, 2019; Istenič Starčič and Lebeničnik, 2020). Among attitudes towards technology integration contributions, are: the impact on improving learning and achievement, the impact on individualization and differentiation, the impact on promoting creativity (Sang, Valcke, van Braak and Tondeur, 2010), self-efficacy, observability of individual work and achievements, flexibility of activities (Van Braak and Tearle, 2007) and enabling new activities that were not possible before the use of technology (Puentedura, 2013).

According to a Finnish survey report from 2006, the digital literacy of teachers covered three levels of the use of information and communication technologies. At the first level was the skill of using text editors and e-mail, at the second level was a more advanced pedagogical knowledge of the development of learning resources and at the third, highest level, which was achieved by only 10 percent of teachers, the use of multimedia, distance learning systems, networking, programming, the use of administrative systems and the use of information and communication technology for research and innovation. (Ristimaki, Niemi, Tissari, Mikkola and Jakku-Sihvonen, 2006)

With the technological development and accessibility of technology, the third level has become the base for all pedagogical workers. With the shift from traditional writing technology to digital technology, the basic concern of the teacher in the context of literacy development is also the development of digital skills (Istenič Starčič in Turk, 2016). At the 25th World Wide Web Conference held in Montreal Istenič (Istenič Starčič and Turk, 2016) presented a model of digital literacy in three di- 
mensions (Figure 2), designed on the basis of three established models (Mishra and Koehler, 2006; Puentedura, 2012; Koole, 2009).

The model of teacher's digital competencies includes technological, pedagogical and content-specific subject knowledge (TPACK model) developed by Mishra and Koehler (2006), captures technological interventions according to the SAMR model (Puentedura, 2013) (Figure 1). The SAMR model (Substitution, Augmentation, Modification, Redefinition) (Puentedura, 2012) outlines technology integration for enhancement and transformation of instruction. Technology supported learning is performed on four levels:

- replace an existing activity,

- to enrich an existing activity,

- to modify an activity,

- to redefine an activity and introduce the activity not possible before the technological introduction.

Figure 1: Technology integration according to the TPACK (Mishra and Koehler, 2006) and SAMR (Puentedura, 2013)

\section{Substitution}

\section{Technological}

\section{Augmentation}

\section{Pedagogical}

\section{Modification}

\section{Content}

\section{Redefinition}

The framework for rational analysis of mobile education (FRAME) by Koole (2009) defines learning emerging from the learner, mobile device and social interac- 
tion. Technology integration (the device) encourages children's development (learner's characteristics) and learning by connecting traditional activities in working with traditional materials and resources (social environment). The teacher plans to integrate technology so as not to impair the natural and cultural environment that is important for the child's learning and development. At the same time, it takes into account the child's life practice with technology and includes it by contributing to learning in the cognitive, socio-affective and psychophysical areas of learning. Koole developed the model referring to the child's zone of proximal development (Vygotsky, 1978). The teacher's task is to support the child in the quality use of technology that promotes the child's development. In the intersection between the device and the social environment, there are characteristics that arise from both dimensions and reflect the potential of the device in the social context. In the intersection between the dimensions of the device and the child are the characteristics and capabilities of the child, which also arise from the social environment and are reflected in the use of the device.

We do not subordinate planning to learning goals that would be decontextualized from the child's life practice and thinking. When planning, we focus on the child's abilities and interests, which make sense of the achievement of learning goals in the context of his life world (intersection of the child's dimensions and social context). When planning the lesson with the process of cognitive empathy, we try to illuminate the process of thinking of students as much as possible. The teacher should anticipate student responses and behaviour (Cerbin and Kopp, 2006).

In 2010, UNESCO issued didactic recommendations for integrating ICT in early childhood care and education by describing the teacher's competencies in three parts. Teachers in preschool should engage in the inquiry of technology and toys, learning about technology and integration of the technology in teaching and learning. The didactic recommendations consist of: understanding and using didactics of digital toys and applications; planning and monitoring children manipulating ICTs in their play; the integration of technology in all curriculum areas; understanding the integration of ICT for developing a child's learning disposition and in the teacher's professional learning. The teacher's competencies for the integration of ICT in preschool include: (1) inquiry of learning technology, (2) learning about 
and with technology and (3) technology integration in a child's play. Understanding the technologies concerns the development of child's skills for communication and collaboration, creativity, socio-dramatic play, and learning to learn. The use of technology in emerging literacy, working with text, developing mathematical and science understanding, developing problem solving skills, developing visual literacy, drawing and painting, media education and musical education. The integration of technology in pedagogical work in preschool basically follows the emerging digital literacy of the child. In the endeavours for developing professional competency, teachers collaborate within institution and across institutions. (Kalaš, 2010 citing Siraj-Blatchford and Siraj-Blatchford, 2006 and Hayes and Whitebread, 2006).

Figure 2: Dimensions of teacher's digital literacy

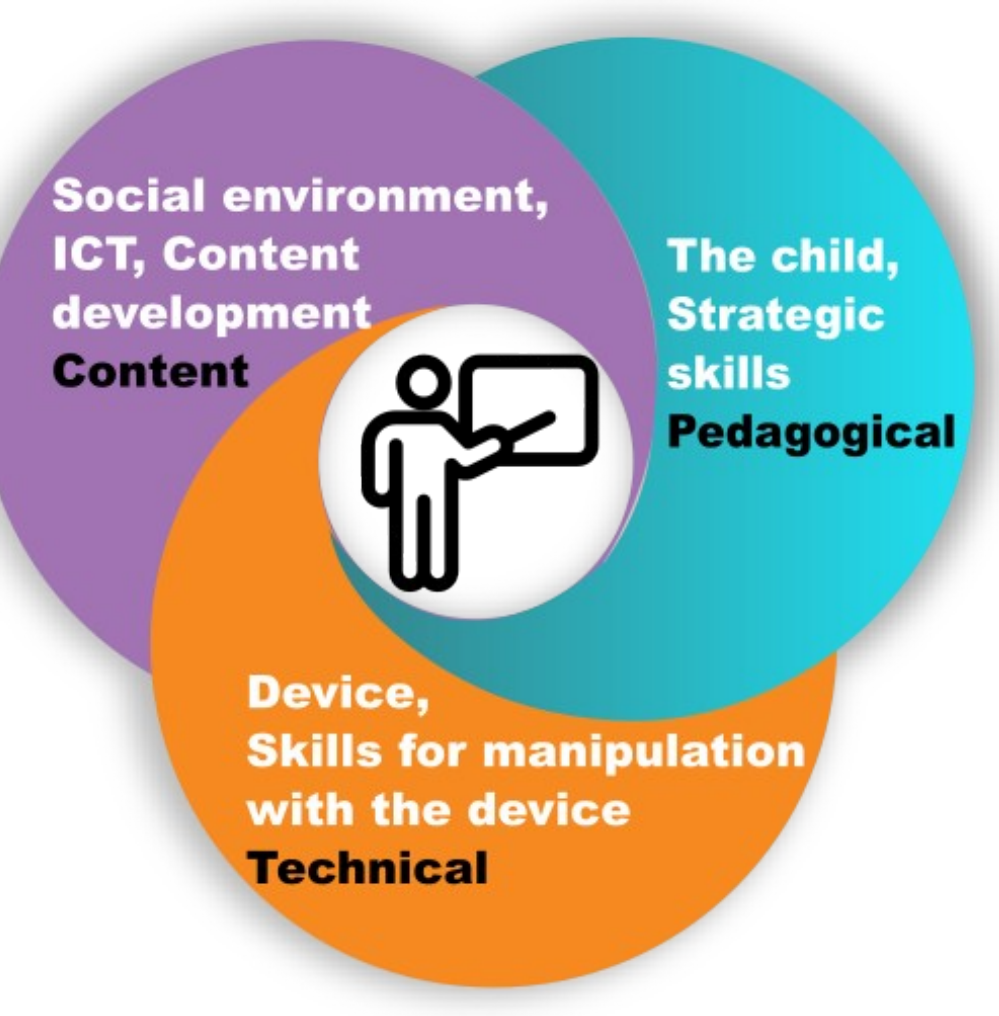


The established model of digital competencies includes the teacher's professional and pedagogical competencies and the development of students' digital competencies (Redecker, 2017). Competences are presented in three sets (Figure 3): (1) professional competencies (organizational communication, professional collaboration, reflective practice, digital continuous professional learning), (2) pedagogical competencies for teaching and learning (teaching, guidance, collaborative learning, self-regulatory learning), digital resources (selection, design, management, security and sharing), student empowerment (differentiation and personalization, accessibility and inclusion, active student involvement), assessment (assessment strategies, monitoring, feedback and planning) and (3) the development of students' digital competences (information and media literacy, communication, content development, responsible use, problem solving).

Figure 3: Teacher's digital competences (Redecker, 2017)

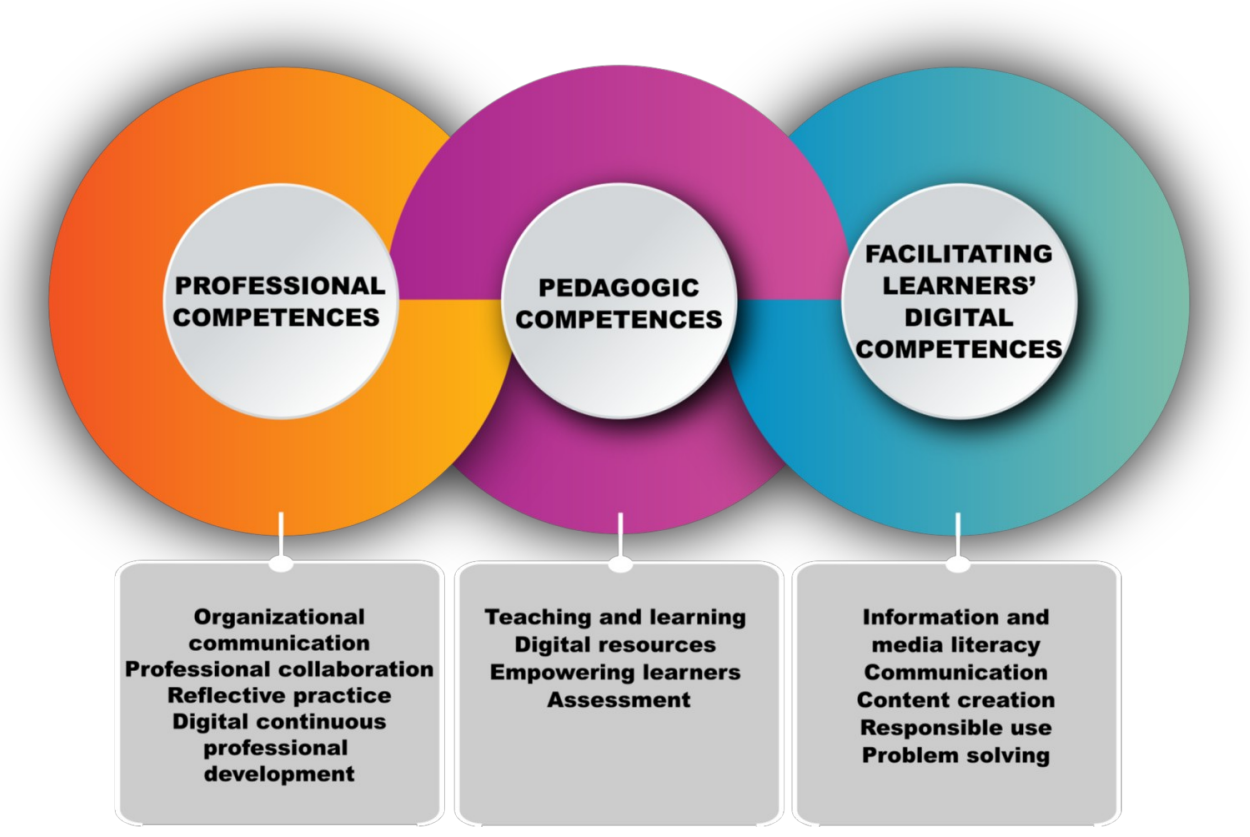




\section{Educational technology in the education process}

Kramar defines the educational process as 'a deliberately planned, socially organized activity in which the participants in the process of education engaging in learning activities achieve set educational objectives' (Kramar, 2009). Within the educational process are material, formal and formative tasks. Material tasks include the development of material or material knowledge, formal tasks include the development of abilities and personality traits, and formative tasks concern the development of a complete personality. Emphasizing the trinity of tasks is important in the planning and implementation of the educational process, as each student and teacher work to intertwine processes within three domains of learning: cognitive, socio-affective and psychomotor (Kramar, 2009). The design of educational technology is influenced by learning theories (Blažič et al., 2003) Learning theories study and explain the processes and factors that influence learning processes and address changes in an individual's functioning and the conditions under which the changes occurred (Driscoll, 2000).

Authors in the United States identify the development of educational technology in the early 20th century with visual and audiovisual teaching aids (Reiser, 2001b). Educational technology in the first two decades of the 20th century focused on visualization within the visualization movement in the classroom, during the development of the first educational films (Reiser and Ely, 1997). Visual aids were designed to support teachers in instruction. The use of visual materials and tools in teaching was complemented by audiovisual resources and aids in the 20th century thanks to technological innovations in sound recording, radio, and moving images with sound (ibid.). Within the movement for the visualization of lessons, it was recognized that instructional aids and media, e.g., visual materials and aids play an equal role in the curriculum with textbooks and teacher's instruction (ibid.). In the didactic triangle, teacher - student - learning content, educational technology in the form of didactic resources and devices constitute a fourth component, teacher student - learning content - educational technology (Kramar, 2009).

In the 1950s and early 1960s, with the communication revolution and the development of communication theories, there was a transition from the study of au- 
diovisual media e.g., materials and teaching aids to the study of audiovisual communication and media (Reiser, 2001b) focusing on the formation of messages using different media in the pedagogical process (printed, film, radio, television, computer). Researchers and practitioners felt that the field covered more than just resources and aids, and began to examine communication theories for the development and use of audiovisual aids and resources (Reiser and Ely, 1997). In the 1960s, the field of educational technology was defined as audiovisual communication, dealing with the ways in which messages are formed and conveyed in guiding the learning process (ibid.). In the 1970s, audiovisual teaching and communication was replaced by a broader field - instructional design and technology (Reiser, 2001b). Even the very name of the professional association in the USA changed from the Department of Audiovisual Instruction (DAVI) to the Association for Educational Communications and Technology (AECT) in the 1970s (ibid.).

Prior to the first official definition in 1963, educational technology was placed within the framework of audiovisual instruction (Reiser and Ely, 1997; Reiser, 2001b). Instructional theories develop teaching models based on learning theory and allow for the definition of the conditions and effects of teacher interventions and support in the learning process (Smith and Regan, 1996). In the 1970s, under the influence of cognitivism and the development of instructional theories, the field was renamed instructional design and technology (Reiser, 2001b). The discussion shifted from the focus on learning content and representational characteristics of visual and audio-visual elements in educational communication, to the design of the learning process and the effectiveness of technologies in learning in relation to the set learning objectives and teaching methods. Cognitive theory had a greater impact on educational technology in the late 1970s and 1980s, although important works were created as early as the 1950s and 1960s. Cognitive theory shifts attention from learning outcomes (outcome orientation) to the learning process (process orientation) and the characteristics of students and the differences between them. At the end of the 1970s, instructional design shaped by learning models began to gain ground, shifting attention from the communicative characteristics of resources to instructional design. 
In the 1980s, with the expansion of microcomputers and information and communication technologies, the computer became well established in education. In the initial period, which lasted from the fifties or sixties to the eighties, the computer was the province of experts with specialist computer programming knowledge. They promoted computers in education for individualization of lessons with (1) practice systems, (2) computer-assisted learning units (comprising text, diagrams, animations), (3) simulation systems (real-world components and experiments), (4) learning tools (for data processing, laboratory work), (5) learning programming (including programming as problem-solving and computer thinking) (Jones, Kirkup and Kirkwood, 1992). The introduction of computers to education supported the processes of leadership and management and teaching and learning (Romiszowski, 1988). Computer-assisted learning resources were among the key capabilities in early computer implementation in addition to computer-assisted teaching systems (Reynolds and Anderson, 1992).

With the development of the Internet in the 1990s, networks also penetrated the field of education. Intensive technological developments in the field of computing and Berners-Lee's concept of the World Wide Web established opportunities for collaboration and wide availability of resources. Self-directed learning using learning resources, open learning environments (Hannafin Land and Oliver, 1999) and computer-assisted collaborative learning were possible. During this period, constructivism influenced process orientation and student-centered learning.

With technological development and introduction of computers, educational technology is no longer conceived solely within the framework of didactic means (within the framework of structural components). With its capabilities it supports the entire educational process, at the structural and process level. Modern digital technologies encompass electronic tools, systems, devices and resources, and enable the storage and processing of data (Victoria State Government Education and Training, 2019).

In the structure of the educational process, educational technology was placed among the structural components (Kramar, 2009), and now we define it as part of the structural and process components of the learning process, which concerns the 
levels of articulation of the educational process from the perspective of teachers and students (Figure 4).

Figure 4: The structure of the educational process

\section{Educational technology as a link}

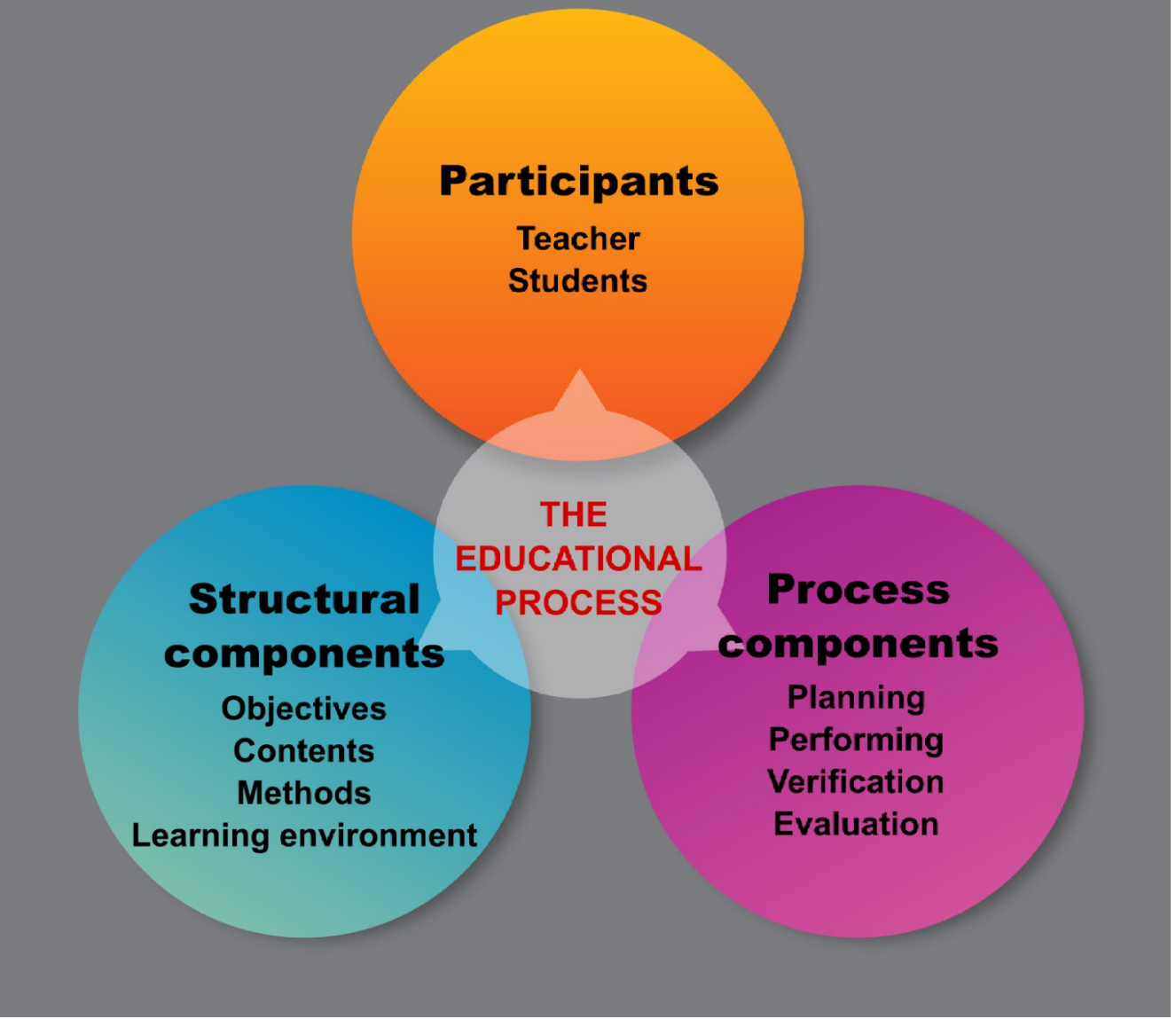

In the educational process, the role of educational technology is discussed in the global context, playing an important role in linking teaching in educational institutions and learning in different natural environments (Strmčnik, 2001). It plays an important role in establishing a learning environment that enables learning related to natural environments, original problems and cultural practices. It enables 
the establishment of an authentic learning environment in three important ways: (1) the use of digital technology for today's generations is an authentic activity and an authentic environment of social life, (2) through the capabilities of modern technology, authentic learning environments can be established by connecting the classroom original environments (natural and other) and (3) a learning environment with all functions can be established in a variety of original environments.

Educational technology supports authentic learning at three levels: (1) learning related to the authentic living environment, (2) learning related to authentic - real life tasks, and (3) learning related to the characteristics of the learner and his interaction in the environment. It enables the approach of the natural environment to the educational process (simulations, virtual reality), the establishment of the educational process in the natural environment (mobile learning), and the establishment of a learning environment that enables authentic tasks and takes into account the original characteristics of students.

At the preschool level, educational technology enables authentic learning, which Dewey (1938) defines as learning that makes sense to a child. Based on Dewey (1943) model of children's impulses to learn in interaction with the environment, Bruce and Levin (1997) classified educational technology in a preschool curriculum based on the child's original activity-play into four categories.

The taxonomy encompasses four types of educational technology: (1) learning by inquiry, (2) interaction and communication as basic for social engagement, (3) construction in play and creativity involving a set of materials and (4) expression (Bruce and Levin, 1997). In the preschool educational process, educational technology supports the child's inherent creative activity, which is a condition of the child's development and is adapted to his inclinations (discovery, interaction, problem solving, construction, creativity, expression). Within the first category, educational technology for learning through discovery and research encompasses a wide range of tools for expanding the senses, for thinking, and for manipulating data. In the second category, educational technology for communication includes a set of tools for message design, interaction and collaboration. In the construction category, educational technology comprises a set of design tools. Within the fourth 
category, educational technology for expression, encompasses a set of tools for artistic, musical, multimedia expression, animation, and composition (Bruce and Levin, 1997).

\section{Educational technology in the global system of factors of the education}

In dealing with the factors of the educational process and the factors of the use of educational technology, we will use the scheme of Bronfenbrenner's (1979) ecological systems theory and Vygotsky's socio-cultural theory (1978) for a broader framework. The concept of practice, which in sociological theory of practice integrates, manifests and establishes human activity and social structures and systems, helps with the explanation (Ortner, 1984). Practices are co-established by different systems (e.g., family, or school). The characteristics of the practice are comprehensibility within individual practices and procedures of activities and communication (ibid.). Practices in the use of digital technology in the family and among peers are important in the planning of educational technology. Bronfenbrenner $(1979 ; 1986)$ model of studying a child within the micro-environment of his family and in the interdependence of micro- meso-systems and macrosystems and their practices is directly applicable in the study of children's digital practices. Vygotsky's socio-cultural theory (1978) deals with children's play in relation to the socio-cultural environment in which digital technologies are a cultural tool.

The use of digital technology is changing family, school, and peer practices in two ways, through proliferation and its ubiquity. In the past, we have talked about the proliferation of technology, which marks its rapid spread in social practices. School practices were characterized by lagging behind other social practices, with technologies introduced more slowly in learning and teaching. In the last decade, we have been talking about percolation, when the spread of technology infiltrates practices between different environments and systems (Istenič Starčič and Lebeničnik, 2020).

Technology is ubiquitous and establishes environments beyond time, geography, or physically defined space. The technological environment is immersive and embedded, and is defined by interaction that takes place in these environments 
(Plowman, 2016). Technology is becoming imperceptible as it penetrates all pores of social life. Researchers point to the inadequacy of the bounded treatment of technology within family or school practice as a predetermined environment (ibid.). If technology was once prominently placed within the home and its practices have affected, for example, the family environment, today technology is becoming increasingly inconspicuous and establishing a context beyond the family environment (ibid.). The study shifts from studying the environment, 'where the practices of using technology take place', to studying by capturing the content of practices or studying 'what technological practices cover in the family environment and beyond' (ibid.).

During the period of the spread of television, the core of research was media content, their representational forms and effects on children's development and learning. Later, studies covered the impact of time spent in front of screens and the colonization of leisure time at the expense of other family leisure activities, the impact of portraying violence, exploiting childhood to promote consumerism (Wartella and Robb, 2011), and how developing popular cultures with digital technology changed children's play and mastered children's media practices (Cook, 2005).

With the development of television, the use of television for educational purposes has expanded. Television shows for children were designed on the basis of curricular objectives. They were broadcast as part of formal learning recommended by educational institutions in television programs with the aim of formal and nonformal learning in children's leisure activities. Researchers have studied the impact of television on a child's learning (Barr and Hayne, 1999). In early childhood, children's television educational shows can have a stimulating effect on cognitive abilities (Ball and Bogatz, 1970), language skills (Rice and Haight, 1990), and prosocial skills (Stein and Friederich, 1975). They studied the impact of different television content on cognitive development and knowledge acquisition (Solomon and Cohen, 1977) iand different combinations of video, audio and speech content, and dynamics (rapid, slow pace) on knowledge acquisition (Huston and Wright, 1983).

Studies have highlighted the sensory characteristics of television. These go beyond the comfort that a child feels when reading, watching picture books, and spon- 
taneous imaginative play, and consequently influence the child's practices (Singer, 1981). They studied how a child's viewing of television affects their spontaneous imaginative play. Singer (ibid.) lists attention, short sequences, and the effect of interference among the main features. Television attracts the child's most attention and distracts her from other activities. The intense dynamics of short sequences affect the child's perception and experience, because the child seeks a similar intensity of stimuli elsewhere. The effect of interference with the intense playback of external representations affects the child's memory and information processing. The child processes external stimuli and perceptions with his own imagination, vocalization of words or sounds, and motor movement. When watching television, she stares at the screen and due to the fast dynamics of events, she cannot process her own perception, which impairs her experience and the imaginary world, which are the basis of a child's imaginary play (ibid.).

The study of the family environment and the active role of parents was conceptualized with the concept of parental mediation, which defines the active role of parents and their way of mediating between the child and the media. Parental mediation theory has dealt with the study of negative media effects on a child's information processing and cognitive development (Clark, 2011).

The study shifted from media content and media effects to the study of technology as an environment and related experiences on a cognitive, socio-affective, psychomotor and sensory level. Socio-cultural theory deals with children's play in relation to the socio-cultural environment in which digital technologies are a cultural tool (Vygotsky, 1978). Through play as an autotelic activity (the play itself is the cause and purpose), the child experiences her socio-cultural environment from an early age, interpreting it with imagination (Vygotsky, 1978). She uses cultural material tools in the play, including digital technology. Psychological tools, sign, speech, and other symbolic systems contribute to the development of cognitive processes that develop using a variety of cultural material tools in a child's interaction with the environment (Vygotsky, 1978).

In society and culture, digital technologies are an important source of socio-cultural practices in all areas, including interaction in the family, school and between 
peers. Researchers in the field of education study digital technologies as the core of socio-cultural content and tools and related practices (Plowman, Stevenson, Stephen and McPake, 2012; Edwards, 2013). Digital technology-related consumer and popular culture practices are permeating children's practices. Children's play and toys are used for sophisticated advertising. Children's needs for toys are media constructed with elements of popular culture. The child encounters toys in television shows, movies, and in computer games.

The modern phenomenon of toy conceptualization takes place through transmedia storytelling through various media channels and forms, such as cartoons, films, and computer games (Gulden, 2015; Jenkins, 2003). Smart toys connect online and offline, virtual and physical environment (Marsh, 2010). Connected toys collect family data that the manufacturers analyze to advertise their products.

The use of digital technologies in children's play and learning is a response to the socio-cultural context in which technologies are integrated (Edwards, 2013). It is shaped by the nature of interaction in society, family, school and between peers. Digital technology as a tool of cognition and learning is included in Vygotsky's socio-cultural theory (1978) in children's play and school practices from kindergarten onwards. The game manifests socio-cultural practices typical of digital technologies.

Researchers see an increasingly blurred boundary between home, school, and the technological environment (Plowman, 2016). In the past, technology was addressed within the family or school, for example, the proportion of exposure to media content. Research has focused on measuring the impact on children's development. When studying technology as an environment, we must consider the establishment of contexts defined by the technological environment and not limited to the family or school. The technological environment is ubiquitous and constantly present and seamlessly enters various social practices. It commands its own practices of communication and interaction between people and technological devices, characteristic of different technological practices.

The environment is no longer spatially or temporally determined and becomes limitless with omnipresent technology, leading us to new approaches in thinking about the relationships between practices, people and technology (ibid.). A 
different approach to the treatment of technology in the everyday life of children and adolescents is needed. The study of children's and young people's use of technology takes place in a context that is not directly related to a spatially or temporally defined environment. The discussion shifts from the study of the immediate environment to the consideration of the context established by the technological environment and not tied to the directly present locally and temporally defined environment (ibid.). The technological environment is characterized by practices defined by spatial and temporal distribution, boundlessness, fragmentation and dispersion, and seamless integration into various family or school practices.

The definition of digital literacy given by Sefton-Green, Marsh, Erstad and Flewitt (2016) reflects a contextual dimension that extends beyond time and space. It is defined as the practice of reading, writing and making sense using a range of digital technologies that take place at events and practices involving both online and offline activities. Digital literacy crosses physical boundaries and the boundaries between online and offline and establishes complex communication outside of time and space (Lander and Sheehy, 2004, In Sefton-Green, Marsh, Erstad and Flewitt, 2016).

When dealing with a child's activity at home or when socializing with peers, the use of a mobile phone and computer is tied to contexts outside the immediate environment. The treatment of the child's activity necessarily includes the child's interaction in the immediate environment and in the contexts established by the technologically supported interaction, which leads to the intertwining of the interaction in the direct and virtual environment. The boundaries between real and virtual, between offline and online activities are blurred (Marsh, 2010; Plowman, 2016).

\section{Educational technology in the structure of the education process}

In didactic theory, the factors of the educational process constitute a complex system of subjects that operate in the context of the department, kindergarten as an organization, family, in the local environment and at the global level of social and natural systems. The educational process consists of structural and procedural in- 
gredients, involving: subjects (teacher, students), structural components (objectives, contents, teaching methods, didactic processes, didactic environment) and process components (articulation of the educational process: planning, implementation, verification and assessment) (Kramar, 2009).

The discussion of the basic structure of teaching has traditionally taken place in a didactic triangle in the relationship between three components: teacher - student content. In the second half of the 20th century, in didactic theory, this triangle was supplemented with didactic means and thus expanded into a four-component structure teacher - student - content - didactic processes (ibid.). In Slovene didactics, the structural components include goals, contents, teaching methods, didactic resources and the didactic environment, while teachers and students are considered among the subjects of teaching (ibid.).

Educational technology is understood in Slovene didactics as a structural component. In the definitions of the structure of teaching Slovene didactics, we find didactic means. Kramar (ibid.) defines didactic resources as resources, transmitters (media) and the work of teachers and students. An overview of the definition and historical development of the concept of educational technology shows that it has gone through several phases, starting with the content and its visualization or audiovisual presentation in the first decades of the 20th century. Even then, it was pointed out that visual aids and tools play an equal role in the curriculum, alongside textbooks and teacher's instruction (Reiser and Ely, 1997). Later it was conceived in the context of educational communication, supported by various technologies that, through their characteristics, enable the transmission or mediation of educational messages (Ely, 1983; Reiser, 2001b). Recently, the discussion has shifted to the learning environment established by educational technology (Istenič Starčič and Lebeničnik, 2020) as a structural and process component. Namely, in the 1970s, with the development of instructional models within the framework of instructional theory, it was defined as instructional design and technology (Reiser, 2001b) and encompasses structural and process components. 
Educational technology is therefore defined in the set of structural and process components that enable the articulation of the educational process by the teacher and students.

Next, we discuss the structural components, the learning environment and the learning objectives. In the introduction, we have already pointed out the influence of technological development and the contextual conception of the learning environment. As noted earlier, when using educational technology, it is important to consider it in connection with digital technologies in the child's family environment, which is not limited to the physical environment at home. Digital technology intervenes in the family environment by introducing socio-cultural practices of consumerism and mass cultures with specific practices specific to technological environments. These include the transmedia practices, for example, toys with the inclusion of various media channels and forms, such as cartoons, films, computer games and didactic games. 


\section{Child's primary environment and digital technology}

The primary environment of the family together with the active role of parents is important for the child's development from birth to school. Digital technology is included in the socio-cultural practices of the family in the proximal environment through social interaction, play and artifacts, influencing the child's daily experiences. The child's primary interaction in the family environment is changed in two ways. Digital technology intervenes in the relationship between the child, the interactive content, and the environment, thereby changing the context in which the child establishes interaction in the family. As Plowman (2016) wrote, a child does not interact in a direct spatial and temporal home environment, the interaction context is established by the technological environment. The manner and process of interactions between the child and parents and other family members have also changed. A digital device becomes an interface for interaction in a family environment that can inhibit interaction or enable new ways of communication. For example, when looking at a screen, parents talk to a child without eye contact, thus impoverishing eye contact communication. The eye contact is key to a child's emotional security and a basic stimulus for her expression and interaction with an adult. When playing with a digital toy or playing a screen game, children enter technological environments that establish a context outside the family environment.

\section{Trends in studying the impact of digital technologies in the child's environment}

With the expansion of television, the study of family digital practices and children's exposure to the media has become intensive. With the proliferation of television in homes, children watch television programs before the age of three and have their favourite shows at the age of two (Guernsey, 2012). The study of children's use of information and communication technologies has, with the expansion of television, problematized the impact of mass media and media content (Wartella and Robb, 2011), especially the negative effects on children's information processing and cognitive development (Clark, 2011). Among these, Wartella and Robb (2011) highlight: studying the impact of time spent in front of screens, the coloniza- 
tion of leisure time at the expense of other family leisure activities, the impact of portraying violence, and consumerism that addresses parents indirectly through children. To this must be added the study of popular cultures that are spreading with digital technology and changing children's play. Consumerism and popular cultures are entering children's media practices (Cook, 2005). The use of digital technology is extremely difficult to separate from consumption. The use of digital technology enables consumption, and consumption encourages the use of technology (Edwards, 2013).

The production of children's programs (Anderson in Pempek, 2005) and the presence of several television sets in the household, which are also in children's rooms, have extended the time children spend in front of screens (Wartella and Robb, 2011). In 2003, nearly 40 percent of children under the age of six in the U.S. had television in their room (ibid.). In the period of ubiquitous mobile devices and the introduction of tablets and smartphones, more and more children own mobile devices. This prolongs their time in front of screens and reduces the age of children who spend time in front of screens. The study of the effects of media violence on children (Bandura, 1977; Singer, 1981) has spread to all digital media since the original study of television viewing. The study covers a range of phenomena: watching violent media content, playing violent computer games, showing various forms of relational violence, such as abuse of friendship and violent messages. Researchers find that media violence affects children's and later adults' perceptions of various social phenomena and, consequently affects the relationships they develop in the circle of family, peers and later in the work environment.

The development of consumerism and popular cultures was accelerated by television by incorporating advertising into children's shows and, in the 1980s, by developing market-based shows that advertised toys (Wartella and Robb, 2011). The development of digital media has accelerated consumerism, as it is no longer determined in time and space of visiting the store. The use of digital technology integrates various forms of consumerism. Children's toys and other products are among the pillars of consumerism. Children's play and toys are subtly marketed with the development of toys spun off from media production products (television series, 
movies, computer games) and smart toys, which they collect data on family practices, allowing the industry to accelerate consumption.

The study of the influences of the media in the family environment was conceptualized while studying parental mediation. Clark (2011) summarizes three strategies of parental mediation from the television period: active mediation as a discussion of media with the child, restrictive mediation as setting rules governing the child's use of media, and co-viewing, which includes parental presence and nonverbal communication. Active mediation through conversation encourages interaction between parents and the child in general, develops critical thinking and critical evaluation of media content (ibid.). Research has put restrictive mediation in front of a co-viewing, while too little restrictive or too restrictive mediation has controversial effects, in a child arouses resistance and a desire for the forbidden (Nathanson, 2002, In Clark, 2011). Co-viewing of television as a family practice that brings family members together has been criticized for saying that the family is only physically united in front of the television screen, which does not encourage and increase interaction between family members (Maccoby, 1951, In Wartella and Robb, 2011). In 1999, the American Academy of Pediatrics indicated the danger of replacing direct interaction in the family with passive television viewing (AAP - American Academy of Pediatrics, 1999). However, some research has also found positive effects on family well-being and structuring family routines relative to television programming (Silverstone, Hirsch and Morley, 1991; Lull, 1980, In Clark, 2011). Research reports on differences between the genders, mother and father, by education and differences in family income. Mothers, higher educated parents, and higher-income families use multiple parenting mediation strategies (Eastin, Greenberg and Hofshire, 2006, In Clark, 2011).

With increased ownership of mobile devices and their entry into children's rooms, parental mediation is becoming more demanding. With the development of information technologies and mobile devices, the theory of parental mediation does not cover the complexity and dynamics with which digital media enter family practices and both negative and positive effects (Clark, 2011; Livingstone, Ólafsson, Helsper, Lupiáñez-Villanueva, Veltri and Folkvord, 2017). Traditional forms of parental mediation are less appropriate and often ineffective in the age of mobile 
technology (Mascheroni and Ólafsson, 2014). Restrictive mediation with technical control is still in use, co-viewing and active mediation are no longer sufficient ( $\mathrm{Li}$ vingstone et al., 2017). In online practices, children are the initiators and lead their parents in adopting strategies, which the authors call reverse socialization(Valcke, Bonte, Wener and Rots, 2010; Livingstone et al., 2017). Clark (2011) addresses parental mediation in conjunction with factors such as parenting style and emotions that are under pressure from the dynamics between technology, family members, and their interests and needs. For example, a child's use of digital media is a cause for concern for parents, while for a child or adolescent, they give joy and satisfaction (ibid).

Research points out that researchers focus more on hazards and negative effects, and too little on opportunities and the impact of digital media use on learning and development, and on active mediation methods to promote learning (Vaala and Bleakley, 2015; Troseth, Russo and Strouse, 2016; Livingstone et al., 2017). Researchers point to the important fact that the use of digital media in the family environment in the preschool period promotes emerging literacy (Plowman, Stephen and McPake, 2008) and the development of dispositions for learning (Plowman, McPake and Stephen, 2012).

Chakroff and Nathanson (2011) cite the positive effects of a child's vocabulary development and readiness for school, the impact of prosocial TV shows on a child's prosocial development, and the impact of playing computer games on spatial and coordination skills. A review of research between 2009 and 2014 on the impact of the use of digital technologies on children's learning between the ages of three and six highlights literacy, inclusion, interaction, mathematics (Zomer and Kay, 2016).

Clark (2011) introduces participatory learning as an alternative to active mediation, in which parents use digital learning media together with their child. At the preschool level, active mediation in the form of participatory learning can also include a guided play with digital technologies., According to research conducted by Plowman, McPake and Stephen (2010; 2012) digital technology use by parents and teachers, contributes to learning and development in three main ways: (1) Develop- 
ing skills to understand the functionality and interactivity of digital media and the child's ability to manipulate them. (2) Expanding knowledge and understanding of the world in various curricular areas through the use of programs, websites and digital books. (3) Developing dispositions for learning in the affective, social, and cognitive fields (Plowman, McPake and Stephen, 2012).

Parents and pedagogical staff in preschool need concrete guidelines on the use of digital and educational technology in different developmental periods, to place digital activities among other children's activities and cover all areas of learning, not just general areas. Researchers in various fields characterize inappropriate polarized views and a generalized view of digital technology as harmful, or describe its use only as positive. Pediatricians point to the balanced recommendations of pediatric associations that address both the negative and positive aspects and potentials of technology for learning and development (Straker, Zabatiero, Danby, Thorpe and Edwards, 2018). Researchers in the field of media studies and education emphasize the need for a comprehensive and contextualized treatment that connects family and school practices while tackling society's demands for 21st century competencies (Livingstone et al., 2017).

Livingstone and colleagues (2017) classified parental mediation into two types: mediation to enable the use of digital technology, and restrictive mediation that controls and restricts. Mediation to enable the use of digital technology is akin to active parental mediation that was established in the days of television. While active mediation mainly involved talking to the child, mediation to enable the use of digital technology supports the child's activity, taking into account the high complexity of digital media. It includes developing children's skills, intervening and encouraging quality use of digital media. Mediation to enable the use of digital technology requires parents to have well developed digital skills and knowledge of the safe use of the Internet, as well as a commitment to the use of digital technologies (Livingstone et al., 2017). Research results show that propensity and experience of use influence parents' choice of mediation style (Valcke, Bonte, Wener and Rots, 2010; Livingstone et al., 2017). 


\section{Digital technology in a child's play environment}

A child is born into a cultural environment marked by cultural tools, and his play is the primary mode of cultural development (Vygotsky, 1978), in which exchanges with intermediaries take place including, in modern society, digital technology. Children's play is essentially an autotelic activity, which makes up a large part of his daily life and is important for his development. Autotelic activity is internally motivated, self-sustaining, and engages the child into its flow (Rautio, 2013). The child plays out of her curiosity and inner need to play. She develops the skills of playing through the game itself as an autotelic activity, in which she includes material, objects from her immediate environment and other forms of exchange and intervention in the environment. Play enables the child to experience the social cultural environment, which she perceives and interprets through play (Vygotsky, 1978). A child's play is a source of development, enabling her to move away from concrete experiences and develop thinking, by establishing an area of proximal development in which the child acts on her abilities (Vygotsky, 1987).

Compared to the socio-cultural view of children's play, cognitive play theory highlights developmentally appropriate play activities, based on the assumption that children's play is conditioned by the child's development. Piaget (1962) describes four stages of a child development of which the first three take place in early learning and development. At the first stage of sensorimotor, the child develops a functional or practical play (movement and senses). In the second, the preoperational stage, the child develops symbolic play and is increasingly involved in a pretend play that allows him to represent experiences in the environment (symbolic play and manipulation of symbols). A special form of play that enables the transition from sensorimotor to symbolic is constructional play which Piaget describes as an accommodation play (Marjanovič Umek and Kavčič, 2001). In the third stage, the concrete operational level, the child develops a play of rules.

Various authors define the game in developmental terms. Hutt (1966) classifies play into epistemological, in which the child explores her environment and her sensory abilities, and ludic, in which she explores with imagination and imagines how she can manipulate various objects from the environment. Bird and Edwards 
(2015) interpret epistemic and ludic play in a socio-cultural perspective, using tools combined in the contexts of epistemic and ludic activity.

In the preschool period, Toličič (1961) classifies play into functional, imaginary, perceptual and creative play. Perceptual play involves listening to fairy tales, observing, imitating, while creative composing, storytelling, drawing, dancing, singing.

Symbolic play establishes a developmental area for the child, in which the imagination enables him to interpret the environment and work on his own abilities (Vygotsky, 1978). Symbolic play is characterized by the interpretation of the sociocultural environment by directing oneself (autosymbol play), role-playing and by moving away from the real situation and overcoming it (Vygotsky, 1978, pp. 99). Group symbolic or sociodramatic play is more complex. In addition to interaction and verbal communication, various forms of symbolic play, imitation, toy-related transformation, or verbal transformation take place (Marjanovič Umek and Kavčič, 2001). In a sociodramatic play, the child relives actual or imaginary experiences in the course of their own reasoning and interpretation (Lindon, 2001).

Through play the child develops many skills, which are an integral part of the play. The opposite is the allotelic game, which is instrumentalized and conditioned by external impulses and goals. The allotelic game includes a didactic game planned according to educational goals.

Digital technology is entering children's play at all levels of development. Along with traditional toys (soft toys, dolls, puzzles, etc.), children encounter digital toys. Digital toys are classified into screen digital toys and non-screen digital toys (Stephen and Plowman, 2014). Children of the touch interface generation are exposed to digital media from birth (Plowman, McPake and Stephen, 2008) and have no pre-digital experience. The child uses various digital devices when playing. Among devices that are not thought of as toys, the child uses a smartphone, tablet, personal or laptop computer, digital camera, digital camera. The child handles the camcorder and camera, listens to music, uses audio recorders and listening devices.

Criticisms of the digital game, claiming that it restricts creation, are rejected by researchers (Bolstad, 2004; Stephen and Plowman, 2014). In creative play, the child 
expresses himself by using different devices, and not just by using selected computer games.

Non-screen digital toys include smart toys (with built-in sensors for recognizing the child's interaction and responses to different parts of the toy) and connected toys (connected to a smartphone, computer, etc., including connected toys that collect and transmit information about the child on the Internet, allowing them to react to the child's interaction). A new area of children's play with the emergence of digital toys connected to the Internet is represented by augmented reality toys and mixed-reality technologies (Yilmaz, 2016) called also Internet of toys. This and supports diverse forms of imaginary play which the child performs by storytelling. The child's augmented playground for individual or socio-dramatic play provides the possibility of embedded narrative in a technology-based learning environment. The diverse set of digital toys and the traditional toys enriched with electronic or virtual multimedia contents add to a child storytelling recording and collaborative features (Lampe and Hinske, 2007). Digital competences for safety of digital toys are very high on the agenda for parents and teachers.

Child's play and imaginary worlds emerge or are constructed by storytelling manipulating physical and digital materiality. The child's imaginary world during play (Fig. 5) transits or merges the physical and virtual environment during the play (Stapleton and Hughes, 2003) and supports diverse forms of imaginary play which a child performs by storytelling. The child's augmented playground for individual or sociodramatic play provides possibility for embeddied narrative in technologybased learning environment. The diverse set of digital toys and the traditional toys enriched with electronic or virtual multimedia contents add to a child storyteling recording and collaborative features (Lampe and Hinske, 2007). The digital competences for safetly of digital toys is very high on agenda for parents and teachers. 
Figure 5: A model of a child's play and imagination constructed by storytelling utilizing physical and virtual materiality (based on Stapleton in Hughes, 2003)

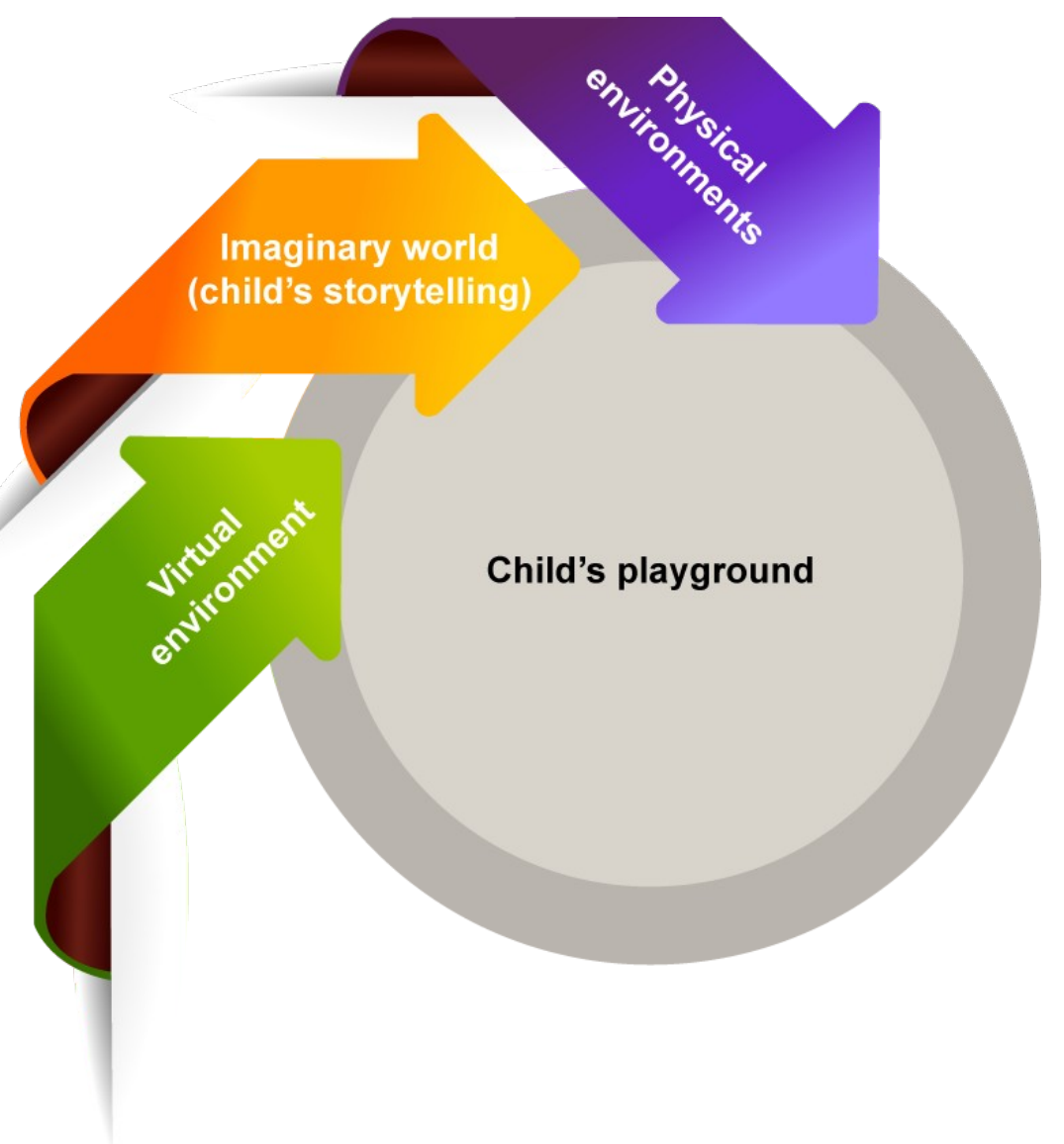

Digital play is addressed through three approaches: examining the extent to which digital activities fall within the scope of children's play; comparisons of traditional and technological toys and identification of possible promotion of new types of play with technological toys; and studying the contexts of children's play and interpreting digital play as a culturally embedded activity (Edwards, 2013). The boundaries between traditional and digital gaming are becoming blurred (Marsh, 2010). In the preschool period, digital play as a culturally located activity is the basis for planning pedagogical approaches (Edwards, 2013). Culturally embedded digital toys and games are also studied from the perspective of a hidden curriculum (Edwards, 2015). The curriculum should include digital technology in several way. 
- The child should use tools and objects in her environment for different types of play, epistemic (enquiry and problem solving), functional or practical (sensorimotor schemes), ludic (symbolic, imaginary, innovative activities). The authors note that technological play reduces the level of complexity characteristic of pretended and imaginative play (Johnson and Christie, 2009; Smirnova, 2011; Edwards, 2015). The digital toy with built-in mechanisms and interactive software is self-sufficient, and carries out activities independently of the child who would guide a digital toy. The child's creativity is thus inhibited, when playing with a toy, such as a doll; the child does not animate her emotions, and built-in interactive mechanisms replace the child's fantasy (Smirnova, 2011). Researchers point to the difficulty of separating meaning from object (Leong and Bodrova, 2012, Edwards, 2013; Bird and Edwards, 2015), which is important in the development of symbolic thinking (Bird and Edwards, 2015).

- Through play, the child learns digital skills and learns the characteristics of digital technologies. She begins to develop digital skills early on, as digital technology enters a child's life very early on. Although play is a fundamental way of learning in preschool, Bird and Edwards (ibid.) believe that we have no insight into the processes of learning a child's digital skills that take place through play.

- When playing with technology, the child learns in various areas and, recognizing this, the development of didactic programs for the preschool level is becoming more intensive. Digital toys and programs developed for home use and for the global market also need to be addressed in terms of a hidden curriculum that addresses cultural traditions and practices and ways of interacting in teaching and learning that should not be uncritically introduced into the child's cultural environment (Edwards, 2015). When using didactic programs, children depend on their developed digital skills. 


\section{Parental mediation in the use of digital technologies}

Parental influence is one of the factors influencing a child's early contact with technology. Parents are the child's role models and intermediaries in his use of the media (Plowman, McPake and Stephen, 2008). The approach to their use also depends on their understanding of technology and its role in children's play. A survey (Plowman, McPake and Stephen, 2012) into the perceptions of parents of preschool children of the benefits of computer use in preschool identified five areas that cover:

- development of computer skills,

- understanding of the world,

- development of dispositions for learning (independence in computer manipulation, which the child can transfer to other areas),

- understanding the role of technology in everyday life from observing adults and when the children themselves become involved in more advanced use,

- encouraging impact of planned activities in preschool educational institutions on family practices.

The role of parents in establishing a safe and supportive environment includes mediation in media use and media literacy (Chakroff and Nathanson, 2011). In both mediation and media literacy, critical consideration of the media and their effects is crucial. Media literacy is multidimensional and includes insights from media studies, sociology, psychology, pedagogy and health. Teachers play an important role in raising parents' awareness, as they deal with these topics in preschool education.

European research describes media socialization (Süss, Lampert and Wijnen, 2009, In Chaudron, 2015), which derives from the basic principle that children should not be excluded from media use, but should use it meaningfully and safely in a variety of areas. Pedagogical approaches include: learning quality use through role play derived from the child's experiences and emotions; parental control of content; the introduction of new media technologies in collaborative activities with the child, drawing attention to the internet safely; writing a diary for the child about the media, news and personal experiences; the child's independent expression, in the 
sense that the experience is not mediated by the parents (Süss, Lampert and Wijnen, 2009, In Chaudron, 2015, pp. 57-58).

Technological toys are increasingly entering children's play. Simple electric and electronic toys or powered toys, which traditionally had a place in a child's environment, are now replacing digital toys and digital devices. A child's play environment increasingly incorporates digital resources and devices. A personal computer on the desk, with accompanying ergonomic requirements, and mobile devices that also allow the child's use in movement enhance technology use at the early stage.

Because of the increased share of screen activities, the child's interaction with adults and children's play, which is crucial for his learning and development, is impoverished. As Figure 6 shows, important daily activities include: (1) parental mediation to enable the use of digital technology through participatory learning and guided play with digital devices. When interacting with a device, tablet or phone, verbal and non-verbal communication with eye contact, body movements, nodding of the head, and movement around the room are important. (2) The child's engagement should be active, not passive. In digital activities, the child is physically active, activating fine motor skills and gross motor movement. Thus, when using a tablet computer or mobile phone, a child can move freely around the room (Volk, Cotič, Zajc and Istenič Starčič, 2018). Interaction with the touch screen and with the manipulation of digital and physical objects is recommended (AAP, 2016). Activities also take place on a cognitive level when the child engages in activities on a digital device. Socio-emotionally, a child is active when interacting with other people around her. Researchers report that parents are aware of the importance of linking digital activities to traditional activities, which involve integrating digital into the child's other traditional play activities (Stephen and Plowman, 2014). 
Figure 6: Digital technology in a child's play in a child - parent interaction

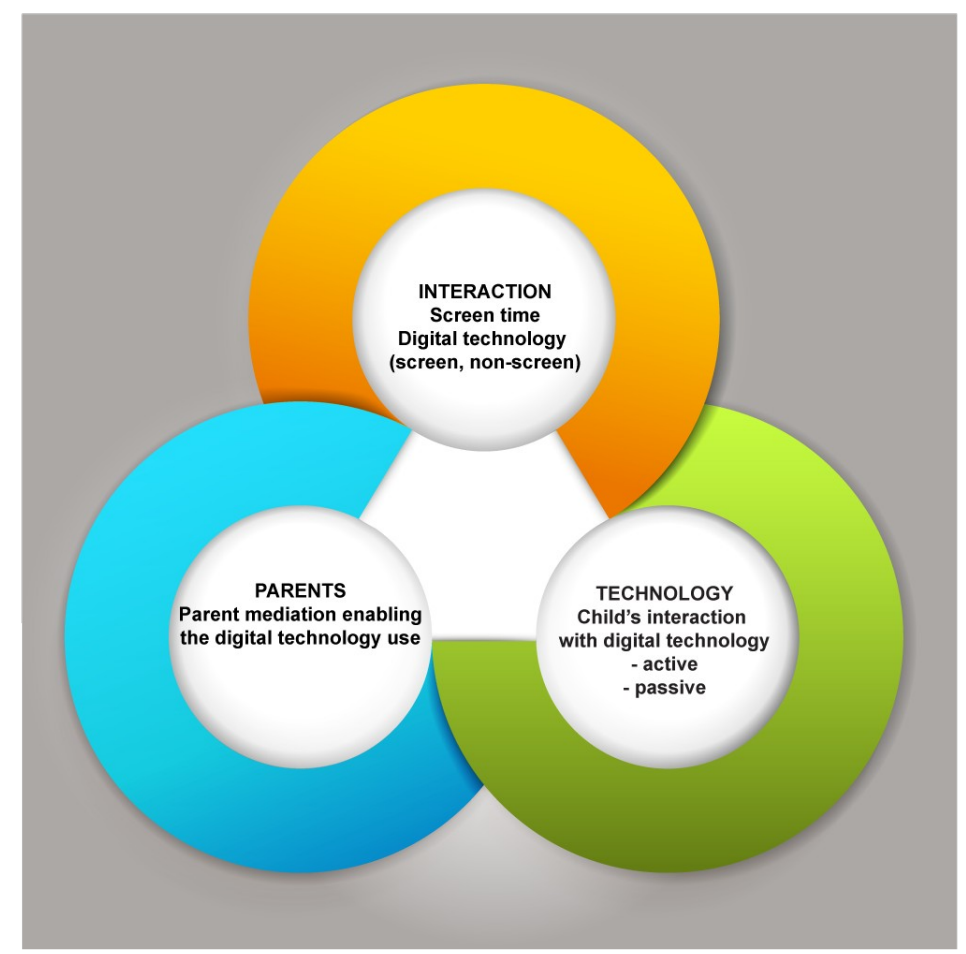

\section{Teachers and parents working towards partnership}

In the preschool period, the child develops through experiences in different environments, the primary environments being the family and kindergarten. Bronfenbrenner (1979) points out the intertwining of different environments and the interactions between them. The development of emerging literacy begins in everyday interaction in the family environment, where digital technology is becoming increasingly (Marsh et al., 2017). When using digital media, children not only develop di- 
gital skills, but also develop dispositions for learning in all areas (Plowman et al., 2010; 2012).

Research shows that a child's primary environment is a source of digital media experience incorporated by the teacher in their day-to-day work in kindergarten. This takes into account the experiences of different environments from which children come and establishes a broader context of socio-cultural practices. The results of research in European countries show that while some parents know and provide their child with quality digital applications, others have no knowledge and have no ideas for their use (Chaudron, 2015). The research emphasizes the teacher's role in raising awareness and educating parents about digital technology and encouraging the child to use it in a quality way (ibid.).

When addressing digital technology at an early age in partnership with parents, teachers follow four key aspects of the role of digital technologies:

- the child's development takes place through play activities in which the child interacts with the environment and with cultural artifacts, with digital activities becoming more widespread,

- digital technologies enable the development of a child's digital skills,

- digital technologies enable the development of dispositions for learning and learning and

- digital technologies and digital skills enable learning in various curricular areas.

Addressing contexts in which digital technology is used at an early age requires ethnographic studies in authentic settings and the involvement of parents as active stakeholders who observe children's activities (Marsh et al., 2015). There is little empirical research that studies in depth the use of digital technologies in a child's early period. Research on the qualitative examination of the family environment from birth to the age of eight included observation and interviews with parents (Chaudron, 2015).

The partnership between teachers and parents includes the participation of parents in the institution and their direct or indirect participation in the educational 
work with the children in the kindergarten and at home. Batistič Zorec and Turnšek (2002) include the field of cooperation between kindergarten and family in the indirect level of monitoring and ensuring the quality of preschool education.

The traditional division into formal (time for meetings and speaking) and informal forms of cooperation (communication and activities agreed by parents and teachers) has been overcome with the support of modern information and communication technologies. Educational institutions use various systems and approaches in establishing partnerships with parents. Among the most widespread are documentation and information systems that upgrade the original functions related to communication and the organization of daily routines. The tools for distance communication and cooperation enable various forms of synchronous and asynchronous communication and thus connect the environments of the educational institution and the family more closely. This enables a better partnership in activities in the field of curriculum planning, implementation and evaluation. Greater transparency of the implementation curriculum is ensured with daily, weekly and annual planning of the teacher's work and digital learning resources. Teachers work with colleagues in their home and other educational institutions and with their parents in planning and designing learning resources. Planning and learning resources can be used to connect kindergarten and family environments.

The partnership between the teacher and the parents stimulates well-being, mutual trust and safety, enables connection and continuity between the two environments (Sheridan, Knoche, Edwards, Bovaird and Kupzyk, 2010) and thus a higher quality of use of digital technologies in kindergarten and home environment. Early learning is marked by two important transitions from home to kindergarten and soon after, from kindergarten to school. Among the key roles of the partnership, Berčnik and Devjak (2017) cite readiness for school by caring for children who are less adapted to the transition from kindergarten to primary school, and the impact on academic performance.

Partnership is based on the motivation for participation of all involved (Resman, 1992). Research shows the diversity of perceptions of children's needs and 
practices in the use of digital technology between families within the same cultural environments and between cultural environments. Some parents believe that digital technology enables a child's development and brings potential for his academic success, while others see it primarily as a risk posed by the use of technology in early childhood (Rideout, 2011).

The cooperation in the treatment of digital media provides mutual insight. The parents know the practices in the family circle, while the teacher is given the insight into the diversity of the children's family practices, which are the basis of the organization of work in the kindergarten. Approaches to this partnership are based on the teacher's sensitivity to the needs of children and parents and on recognizing parenting style, which also takes place in less transparent and tangible ways, and not just in the form of events such as parent meetings and workshops (Jeynes, 2011). The partnership is based on trust, is established mutually, for the duration of the kindergarten program, and is reflected in daily activities. The teacher and the parents share their experiences of the child's family and kindergarten play environment and connect them into a comprehensive experience. In the partnership, the teacher obtains information about the child's daily experiences in the home environment, play habits and interests, daily feeding routines, exercise and the child's current development. Digital technology intervenes significantly between daily activities and routines in various fields. Pediatric associations and researchers therefore monitor the use of digital technologies among the key factors of the child's environment (daily activities, nutrition, exercise, use of digital technologies), with their potential and effects on development and learning (Bellows, McCloskey, Clark, Thompson, Bekelman, Chamberlin and Johnson, 2018).

When establishing a partnership, there is an agreement on ways of communication and cooperation in the field of digital technology, their use at home and in pedagogical approaches in kindergarten. The partnership includes joint activities, such as discussions and exchange of experiences, activities of parental mediation and observations of the child working with digital technology in the home environment. Considering that the environment of home and kindergarten interact and involve all partners with their different socio-cultural experiences, the professional experi- 
ence of parents (Bronfenbrenner, 1979) also has a significant impact on the child's use of technology in the family environment. digital practices in preschool.

The partnership between the teacher and the parents does not mean that the teacher offers parents instructions for home activities, but rather, mutual cooperation in planning and reflection on working with the child both at home and in preschool (Karila and Alasuutari, 2012). In the field of digital technologies, the partnership takes place in several aspects of integrating digital technology into the curriculum, which is implemented in the kindergarten linking with the home environment:

- taking into account the child's play habits and interests in integrating digital technology into the child's spontaneous play;

- parental mediation in the use of digital technology to learn about technology and develop digital literacy (Livingstone et al., 2017);

- understanding the child, his skills and the potential development of digital skills, which indirectly contributes to the use of digital technology for the development of dispositions towards learning in different areas of the curriculum;

- getting to know and critically evaluating various applications, didactic programs, their pedagogical and didactic values and suitability for different development periods by curriculum areas;

- partnership in the implementation of the preschool curriculum.

Establishing a partnership is a lengthy process. It takes place in stages that enable the preparation of a partnership, the analysis of needs and goals, the formation of a common vision and plan, and the planning and evaluation of partnership processes (Bryan and Henry, 2012). The establishment of a partnership is guided by the principles of democracy, justice and empowerment (ibid.). The Slovenian curriculum for kindergartens considers the principle of cooperation with parents to be one of the foundations for the implementation of the curriculum for kindergartens.

The teacher establishes a partnership with the parents and creates a working group for the analysis of the situation and for planning the integration of ICT in the activities of the kindergarten. She can prepare observation instruments, which 
can involve surveys or interviews with parents, or develop an observation protocol to monitor and record activities over a period of time. Audio, video or photoanalyses are sensitive when sharing and dealing with different stakeholders, but they enable parents to observe and record better with the help of audio documentation, video viewing or documenting the child's daily activities through photography. It is important to process the results together with the parents.

In collaboration, the use of groupware and social media contributes to workflow and intensity. The documentation and information systems are integrated with collaboration tools (Istenič Starčič and Vukan, 2019). Computer-aided communication enables quality and effective cooperation, as it takes an integral place in an authentic family environment. The technologies allow for simulation, exchange of examples of good practice and discussion of the risks associated with overuse or inappropriate uses of digital technology. Parents are introduced to the methods of parental mediation in the use of digital technology and the differences between them, mediation for enabling the use of digital technology and restrictive mediation (Livingstone et al., 2017). It promotes ways of sharing technologies with children and building a shared understanding of the role of technology in everyday life. Parents need to recognise the value of parent - child cooperation which makes a contribution to childhood. It offers and insight and important information for the development of their own understanding of children's practices and maintaining their close contact and communication about technology with the child in future child developmental periods.

Parents and teachers in collaboration, carry out the observation is over a defined period of time, for example over a week, applying existing observation protocols. For example, the observation protocol in a European survey in seven countries included a description of the environment (presence of devices, toys, access to nature, playgrounds, libraries, gyms, cinemas, etc.), observation of digital activities, observation of digital devices in children's use, observation of children's skills devices, observation of parent-child behaviour with digital devices, and parental mediation (Chaudron, 2015). 


\section{Recommendations and risks}

As early as 1996, the National Association for the Education of Young Children in the United States emphasized that technology played an important role in all areas of life and that its importance would increase in the future (NAEYC - National Association for the Education of Young Children, 1996, In Rosen in Jaruszewicz, 2009). The recommendations of NAEYC in U. S. (2012) for the age from birth to age of 8 years are based on the assumption that technology is potentially harmful to children and should be selected and protected from its harmful effects. The advantages of learning technology are also emphasized, which requires the support of planned interventions, and integration should be combined with traditional activities, which should not be replaced by digital activities (NAEYC, 1996). The recommendations of the American Academy of Pediatrics (2010; 2011) do not recommend viewing screens for children before the age of two, and controlled view ing in the presence of their parents for children after the age of two, up to a maximum of two hours a day. Experts point out that children develop attention to television immediately after birth, which they attribute to a child's exposure to lit television in the background, even during a child's play or interaction with an adult (Anderson and Pempek, 2005).

The recommendations of relevant pediatric associations, such as the American Academy of Pediatrics (AAP, 2016) and the Canadian Pediatrics Society (Canadian Pediatrics Society, 2017), are slowly changing. Polarized treatments shift to a more balanced treatment of the negative and positive aspects and potentials of technology for learning and development (Straker et al., 2018). The updated 2016 recommendations encourage the inclusion of touch interfaces in toddlers' learning, which should enable play with traditional toys-like interactive activities. The American Academy of Pediatrics recommends the inclusion of activities with touch interfaces at the age of 18 months. For the age group between the ages of two and four, they recommend the use of quality didactic programs. When using, they recommend parent-child interaction (AAP, 2016). The Canadian Pediatric Association highlights the benefits of learning and development in the first place, followed by the risks (Canadian Pediatrics Society, 2017). 
Australian health organization recommendations discourage viewing screens and using digital technology before the age of two. The recommendations also concern parent-child interaction and limiting the involvement of digital media (Australian government department of health, 2012). The Australian Children's Education and Care Quality Authority integrates digital technology into the learning objective, 'A successful child in communication' in the preschool curriculum (Council of Australian governments, 2009) The child works with different texts and develops meaning (multimedia texts are mentioned in this connection), the child presents ideas and establishes meaning using different media and the child uses ICT in accessing information, researching ideas and presenting their thinking (Council of Australian governments, 2009). They make recommendations for digital play and the use of technology to develop children's skills for learning and social interaction(Straker et al., 2018).

With premature and excessive use, the benefits of playing and learning can become risks. The child's immediate environment is formed by interaction with adults and peers. In the earliest period, touch is required for a child's development (Serra, Miguel, Moura, Sampaio and Pereira, 2020). Parental interaction with the child is based on non-verbal communication, movement, eye contact, facial expressions and touch, which establishes a safe environment and promotes the socio-affective, cognitive and psychomotor development of the child. Research points to the role of touch in non-verbal communication with eye contact and facial expressions in the mother's play with the child (ibid.).

Introducing a mediator in the form of a tablet or smartphone into interaction and play can impoverish and limit verbal and nonverbal communication if a child and an adult stare at the screen. Playing with a tablet should include all forms of non-verbal communication, as in playing with toys and other objects. Parents guide and challenge the child in play or accompany her in her spontaneous play, with touch and nonverbal communication being key. Using a computer to replace a child's play, movement activities, and interactions with parents, teachers, or peers is a risk to a child's development and health. The study of digital technology in children's and family routines in the preschool period is included in interventions to 
promote healthy eating and exercise habits that are embedded in the cultural context of families 'digital practices (Bellows et al., 2018).

The entry of intermediaries, such as tablets and smartphones, changes the way children and parents communicate and play. The child communicates with movement, with non-verbal communication, at the earliest period. Eye contact between an adult and a child is important, but there is less eye contact with the inclusion of screens, even when parents are communicating with the child at the screen, as the views are fixed on the screen. Digital toys can complement traditional toys and stimulate a child's creativity or inhibit it (Johnson and Christie, 2009). Due to the increased proportion of activities with the screen, the child's play is depleted, which is crucial in her learning and development (Singer, 1981; Johnson and Christie, 2009; Smirnova, 2011). The increase in audiovisual stimuli in the media results in a decrease in interest in fantasy play. Digital technology can reduce or curtail spontaneous children's play.

Research shows an increase in screen viewing, which has the effect of reducing children's interest in reading and declining reading (Singer, 1981; Rideout, 2011). Exposure to violence on screens and playing violent computer games influence social development and prosocial and antisocial behaviour (Bandura, 1977; Singer, 1981). Increased exposure to violent content reduces negative emotional responses to violence and empathy (Anderson, Gentile and Dill, 2012), impairs general wellbeing, and causes attention and sleep disorders (Howard-Jones, 2011).

Pediatricians list potential dangers in the physical, cognitive, emotional, and social fields. In the field of the child's physical development, they state: twisted posture, repetitive movements, accidents and an increased share of sedentary activities at the expense of motor skills, which leads to a slowdown in musculoskeletal and motor development. In the cognitive area, they report decreased attention, reduced opportunities for verbal interaction, problem solving, and creativity. In the emotional realm, they mention probability for addiction, depression, access to inappropriate content, and advertising, and in the social realm, isolation, reduced face-toface interaction, violence, and predatory paedophilia (Straker et al., 2018). 
The increased use of technology within the family increases the risks of problematic Internet use in the early years and later in life. European research has summarized five criteria of Internet addiction (Grüsser and Thalemann, 2006, In Chaudron, 2015, pp. 55):

- the reduced ability of regulation of negative emotional state (use of the device takes place as a form of stress management and regulation of negative emotions with positive arousal and relaxation),

- raising tolerance (the desired effect of regulating negative emotions can be achieved by increasing the frequency and time of use),

- symptoms of deficiency (reduction or discontinuation of use causes tension, irritability, aggression, decreased attention to all but the right applications),

- loss of control (user does not control use and self-regulation).

A quantitative study in Belgium identified the following aspects among the psychosocial problems of which parents are aware of (Chaudron, 2015, pp. 20-62):

- technologies attract and are associated with uncontrolled overuse,

- the gratification offered by the use of digital devices and games leads to addiction,

- feelings of boredom in the child, which parents should manage with a variety of activities and the development of the child's interests,

- hyper-stimulating adrenaline games and mood swings,

- mental irritability and eye strain. 


\section{Educational technology in structuring the educa- tional environment}

In Slovenia, the kindergarten curriculum defines children's play as a key child's activity, representing a way of children's learning and development and naturally combining the basic principles of preschool education that goes beyond involvement in an academic or developmental approach (Bahovec et al., 1999, pp. 10-11). Game-based curriculum is prevalent in early learning. Play is an autotelic activity, in which she experiences her socio-cultural environment, when in the process of interpretation, she connects play and reality through imagination (Vygotsky, 1978). In play, children draw from the social and cultural environment with the fundamental purpose of play as an autotelic activity interpretation, that is self-serving and in which the child develops and improves her play skills. In the context of kindergarten curriculum, play is defined as a basic activity that connects curricular areas (motor skills, language, arts, social studies, science, mathematics) in achieving educational objectives according to the principles of quality education in kindergarten, which allows the child activities with objects and gaining social experience (Bahovec et al., 1999, pp. 10-11).

The development of preschool education as preparation for school, to enable uniform preparation and experience for all children in the period of emerging literacy, has been criticized for its excessive curricular orientation and establishing a learning-play dichotomy for not taking into account children's natural and social conditions (Weissberg, Hirsh-Pasek, Golinkoff in Kittredge in Klahr, 2016; Ilgaz, Hassinger-Das, Hirsh-Pasek and Michnick Golinkoff, 2018). Preparations for school, intended to perform a compensatory function with didactic approaches that are narrowly focused on basic literacy and the development of school readiness skills, undermine the child's spontaneous play, which is the child's original activity of language development, cognitive and socio-cognitive abilities (Ilgaz et al., 2018). Marjanovič Umek and Kroflič (2009) drew attention to critical developmental periods in which the kindergarten establishes a stimulating environment of formal and non-formal learning in connection with the child's family experiences and their various cultural practices. The organization of work in kindergarten requires interdisciplinary approaches, the promotion of speech development, which significantly 
affects all areas, the development of methodologies in all curricular areas, understanding the hidden curriculum in routine activities and taking into account the diversity of children (Marjanovič Umek and Kroflič, 2009).

In the kindergarten there is free and guided play. Guided play provides a balance between taking into account the child's natural abilities and learning needs through play as an autonomous and autotelic activity and adult leadership (Weissberg et al., 2016). Through guided play, the teacher co-establishes the play environment for the child's participation, taking into account the child's characteristics and in child-centered teaching, takes care of establishing a learning environment in all curricular areas by creating a child's area of proximal development (Vygotsky, 1978). Research has shown that a child's spontaneous play alone does not contribute to a child's development in language and mathematics, and that different approaches to traditional teaching are not as effective as guided play (Ilgaz et al., 2018). A special form is the didactic game. Didactic toys are designed for the development of specific learning areas, are highly structured for certain uses, and target the child's play and thus limit it (Fekonja, 2001).

A child's core activity is play, in which a child develops play skills (Vygotsky, 1978). With it, she expresses himself independently because of the play itself, and not because of the products that are created in the play, or because of the skills that she develops in the play. In a child's play-creature, she is expressive because of her inner need, and not because of her reaction to stimuli from the environment. In the play, the child acts divergently, the activity takes place in different directions, when she explores and manipulates artifacts in her environment (Ivić, 1981).

In organized preschool education, theorists have pointed out the importance of an appropriate balance between free and guided play and the inadequacy of excessive substitution of children's free play with didactic games (Weissberg et al., 2016; Ilgaz et al., 2018). 
Educational technologies in the play-based curriculum are included in different ways:

- Digital technology and toys are an integral part of the cultural tool-kit with which the child becomes acquainted in spontaneous play.

- In preparation for school, guided play has the function of enabling appropriate development for all children in all curricular areas. The child's development is influenced by a combination of environmental factors, various means of play and social interaction. The integration of digital technology takes place in kindergarten in a guided play for the development of language and mathematical literacy, artistic expression, motor development, learning about nature and society.

- Integrating digital technology in such a way that the play takes place while connecting the cognitive, psychomotor and socio-affective areas of learning.

Digital technology is part of the socio-cultural environment, tools and practices that are an integral part of a child's play. Although modern technology has changed even the simplest operations of an individual's everyday life in all areas of social life, the use of technology is not integrated across curricular areas (Yelland, 2005). Critics point to the prevalence of approaches that treat digital technology as limited to the development of digital skills, ignoring the complex role of digital technology and its role in society, the family, and children's lives (Wohlwend, 2010, In Edwards, 2015). These approaches also include the inclusion of only didactic digital play without the inclusion of digital play in the free or spontaneous and guided play. An example of an Australian preschool curriculum incorporates digital technology into learning objectives, 'A child is successful in communication': The child works with different texts and develops meaning (multimedia texts are mentioned in this connection), The child presents ideas and makes sense while use different media and the child uses ICT in accessing information, researching ideas and presenting their thinking (Council of Australian governments, 2009).

The Slovenian curriculum for kindergartens (Bahovec et al., 1999) opens up space for activities in all three areas identified by Plowman, McPake and Stephen 
(2012) as giving examples of audiovisual media activities for the age group from the age of three to six:

- Activities to develop an understanding of the functionality and interactivity of digital media as well as the child's ability to manipulate them:

- recording with camera, camcorder, voice recorder, taking photos,

- watching movies in the cinema, on television or movies made by the child herself or by parents, teachers,

- getting to know different television programs.

- Expanding knowledge and understanding of the world in various curricular areas through children's use of programs, websites and digital books when she:

- uses multimedia games and educational programs,

- reads and invents a story,

- cuts and composes new scenes, creates new contents and artistic compositions, complements them with drawings and printed pictures and details, creates a script in the form of a comic strip.

- Development of dispositions for learning in the affective, social and cognitive areas when she:

- imagines and creates dance inserts for drama performances and video,

- listens, imitates and depicts sounds from nature and the environment,

- imagines, selects and designs puppets, costume elements and scenes for dance, drama and audiovisual activities.

\section{Didactic principles}

The discussion of the inclusion of educational technology in educational work in kindergarten is rounded off with didactic principles (Šilih, 1970; Blažič et al., 2003; Strmčnik, 2004; Ivanuš Grmek and Javornik Krečič, 2011; Kramar, 2009), which integrate principles of the curriculum for kindergartens (Bahovec et al., 1999, pp. 10-11).

The first principle, the learning activity in the child's development, concerns the integration of educational technology in accordance with the child's abilities. The inclusion of technology in itself does not make sense if it is not planned and 
embedded in the structure of the educational process. Strmčnik discusses learning activity according to the type (motor, emotional, intellectual), form (reproductive, productive, creative), guidance (external, self-guided) and the connection of lower and higher forms of activity (Strmčnik, 2001). In educational activities, it is crucial to take into account the child's activities, her initiatives and to provide her with the possibility of active participation.

In the preschool period, the learning activity is a free or a guided play. Managing and monitoring activities enables the teacher to continually adapt, to integrate new activities at the appropriate time and to identify critical periods for learning. This digital play covers all types of play and is not just for learning digital skills (Edwards, 2013). The play enables the child's authentic / original creative activity, which is a condition of the child's development and is adapted to her inclinations (discovery, interaction, problem solving, construction, creativity, expression). Digital technology makes up the cultural environment with which the child interacts and includes it in play. Digital play can be integrated into traditional activities or act as a stand-alone activity, giving meaning to children's functional, sensory and imaginary worlds. Within the curricular areas, we enable the child to use digital technologies for functional, lucid, epistemic and other forms of play. It is necessary to ensure the integration of learning areas (cognitive, socio-affective, psychomotor), because the child learns using all sensory systems, perception, physical manipulation, movement, vocalization and verbal expression). The Curriculum for Kindergartens (1999) dictates that organized activities respect the child's intimacy and ensure safe, harmless activities.

The second principle, the unity of the concrete and the abstract, is interesting in the preschool period from the point of view of dealing with the digital game and its potentials in the transition between different representations. Some researchers critically evaluate digital play, saying that it reduces the level of complexity characteristic of imitative and imaginative play (Smirnova, 2011; Edwards, 2015) and that it makes it difficult to switch between the concrete and abstract perception necessary for the development of abstract thinking in primary school (Leong and Bodrova, 2012; Bird and Edwards, 2015; Edwards, 2013). 
The third principle, the structure and systematicity, concerns curriculum-coordinated planning and integration of digital technologies, the integration of curricular areas and the type of play. In this context, it is important to take into account the gradual progress and promotion of the child's discovery and inquiry, as well as the development of cognitive and experiential skills. During implementation, it is necessary to check the child's understanding and skills. The teacher connects the activities in the kindergarten with the experience that the child has with digital activities at home.

The fourth principle, dealing with problems in the preschool period is the basis of the child's epistemic game from the earliest period. The child's tendency to solve problem situations independently is crucial, and therefore the teacher should strive to constantly set challenges with problem situations that allow the child to experiment and work experientially. These situations encourage the child's activity at the core of pedagogical activity. The child must be able to work collaboratively to solve real problems in the family, with peers and with the teacher.

The fifth principle, individualization, concerns the integration of digital technology in the knowledge of the concrete characteristics of the group and individuals. Individualization makes it possible to bridge the differences between children and to organize activities in such a way that we enable each child to express and create her own. It concerns both skills in handling technology as well as skills in various curricular areas.

Digital media play a key role in spreading consumerism and the global effects of dominant cultures. In integrating digital technologies, the teacher has an important role to play in incorporating incentives from the child's immediate environment, which enables the child to experience authentic cultural activities. It is important to address the real-life issues that arise in a child's vicinity and offer her an authentic environment of imagination and reality. The learning environment must allow for the diversity of experience offered by such a complex and heterogeneous environment that is as close as possible to the child's authentic environment. The children's world consists of a real-life and imaginary environment, which must be involved in the joint establishment of a learning environment in which the child has an active 
participatory role. Internet resources developed by foreign providers, decontextualized from the child's authentic environment, will abstract the child's immediate environment. The child's original activities and content, when placed in the child's authentic environment, are of key importance for the child's development.

The teacher, according to Bronfenbrenner's (1979) ecological systems theory, reflects on the presence and role of technology in a child's life and on the competencies and skills she will need in her life (Rosen and Jaruszewicz, 2009). It is important to know the child's practices in the family environment, which are studied in interaction with socio-cultural practices. Research and monitoring must take place in an authentic family environment by examining the technological contexts established by digital technology (Bronfenbrenner, 1979; Plowman, 2016; Tudge, Brown and Freitas, 2011). When planning, it is important to address a specific group and environment. This requires knowledge of the actual situation in families and takes place in partnership with parents, when teachers together with parents analyse the situation and plan approaches to inclusion in the implementation curriculum.

Seventh, we consider the principle of inclusion. The principle of inclusion in education ensures active inclusion in the learning environment for children with different needs and preferences. The teacher is faced with the need to plan the learning environment by including various sensory systems that will enable quality learning for all students. Inclusion is a principle of adapting the environment to individuals and does not set requirements for the child to adapt to the learning environment (Opara, 2005). The integration of information and communication technology solves the dilemmas of inclusion at the level of identifying special needs, curriculum planning and establishing a learning environment (Norwich, 2008, In Istenič Starčič and Bagon, 2014). From the assistive and compensatory function of information and communication technologies, there is a shift to the planning of teaching according to the principle of differentiation and individualization (Istenič Starčič and Bagon, 2014). With artificial intelligence, modern robotic technology for children with special needs is included at the preschool level (Rosanda and Istenič Starčič, 2019). The W3C consortium, a leading community in the field of Internet accessibility, is responsible for standards of universal design by implementing the fundamental principle of the Internet - its accessibility for all (Berners-Lee, 
1997). Standards include accessibility, usability, and inclusion (W3C, 1997). Research on the accessibility of content on websites shows a relatively low level of accessibility, and this will need to be further improved in the future (Debevc, Kožuh, Hauptman, Klembas, Lapuh and Holzinger, 2015).

Although in the past the digital divide was associated with access to technology, and more recently, mainly with skills for the use of technology, technical access remains a barrier for people with disabilities (Lebeničnik and Istenič Starčičč 2020; Istenič Starčič and Lebeničnik, 2020). Technical barriers can be socially constructed (in the design of the learning environment) (Kumar and Owston, 2016, In Lebeničnik and Istenič Starčič, 2020), cognitive (beliefs), affective (attitudes) and contextual (importance for the individual) (Straub, 2009, In Lebeničnik and Istenič Starčič, 2020). In her work, the teacher should show sensitivity to the establishment of an environment in which all children will be able to participate and express themselves, regardless of their specifics and needs (Opara, 2005).

\section{Genres of play and educational technology}

Children's technological play takes place in several ways. The child uses tools and objects in her environment for epistemic, functional, and ludic play (Hutt, 1966, Bird and Edwards, 2015). With the game, she progresses in all areas of learning to use technology. Plowman, McPack and Stephen (2012) see the three-fold contribution of digital technology to learning: (1) Developing skills to understand the functionality and interactivity of digital media as well as developing the ability to manipulate them. (2) Expanding knowledge and understanding of the world in various curricular areas through the use of programs, websites and digital books. (3) Development of affective, social, and cognitive dispositions for the learner (Plowman, McPake and Stephen, 2012). Bird and Edwards (2015) analyse the technological epistemic and ludic game as defined by Hutt (1966, In Bird and Edwards, 2015 ) in the context of Vygotsky's socio-cultural theory (1987). In the case of the use of a camera, tablet computer and personal computer, they analyse the alternating implementation of epistemic and ludic games. We extended their approach with a functional game (Piaget, 1962) and present it in Figure 7 in the context of learning digital skills and learning dispositions (Plowman, McPack and Stephen, 2012). Epi- 
stemic play involves exploring and solving problems in finding the answer to the question, 'How does an object work?' (Hutt, 1966). Functional play concerns children's sensorimotor schemes (Piaget, 1962). Ludic play involves symbolic, imaginative, and innovative activities in finding the answer to the question, 'What can I do with an object?' (Hutt, 1966).

Figure 7: Digital play supporting digital skills in curriculum areas and development of learning disposition in all learning domains

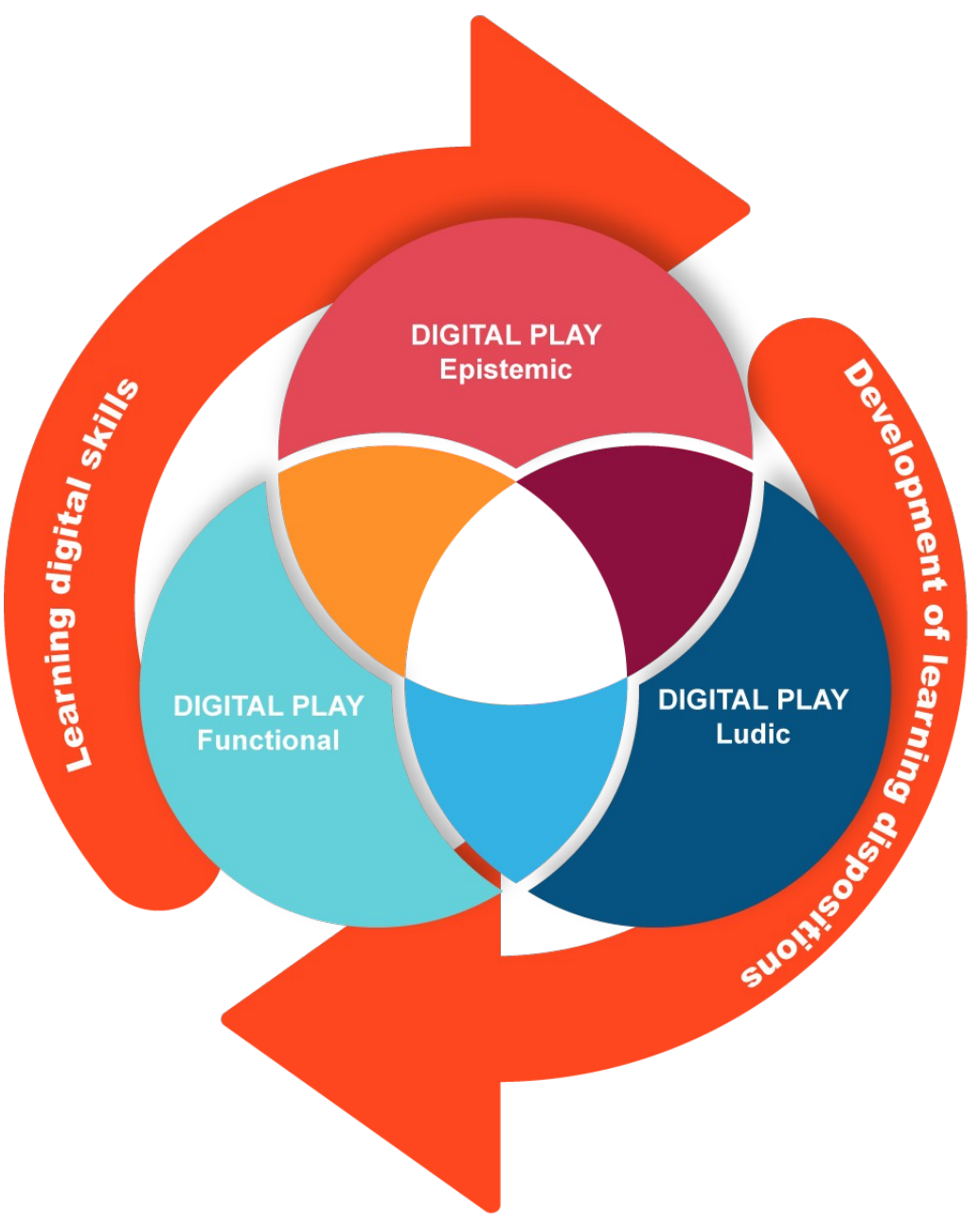


Epistemic exploration play involves using and testing different computer interfaces, testing computer settings, and exploring in a variety of applications. We talk about epistemic problem-solving play when a child solves various problems by manipulating a device or program. She can work with peers or adults to solve problems. Epistemic games with the development of skills includes both the handling of devices as well as the imaginative game with the substitutes of devices or pieces of non-functioning devices (for example, keyboard, screen). The child tests and deliberately performs the wrong operations while training his skills.

Functional play takes place using different programs with the inclusion of different sensorimotor schemes, vision, hearing, graphomotor skills, motor skills and hand-eye coordination. The child uses a variety of digital toys and applications with a touch interface for perceptual movement and exploratory play. She researches her own abilities and abilities of objects, developing her perceptual-motor skills (Marjanovič Umek and Kavčič, 2001).

Symbolic play involves playing computer games or using devices, replacements, and non-functioning pieces of devices in a variety of imaginary situations. Through digital means, the child performs various forms of symbolic play, using different ways of presenting (symbolizing) objects, which enable her to transform objects or representations and transition from object activities to more general play activities (Marjanovič Umek and Lešnik Musek, 1999, pp. 28). The child relives actual or imaginary experiences in symbolic play (Lindon, 2001). When playing with digital media, children use virtual toy manipulations, manipulating the screen, or combining tangible toys with screen manipulation.

A child can play the role of an adult, for example in online banking, online shopping or by appearing in front of the camera. She pretends to carry out computer or internet activities in a variety of ways. Group symbolic play can also take place next to a computer in several ways. While playing with peers and using various toys, the child performs various types of fictional internet activities (video conferencing meeting, virtual gathering of friends). She can perform everyday activities typical of digital media without objects, replacing an object with another, expressing emotio- 
nal and instrumental behaviour in imaginary activities. The child uses various computer programs for symbolic play, such as storytelling.

\section{Educational technology in structuring learning objectives and ergonomic characteristics of its use in learning domains}

Learning objectives are a fundamental component of the educational process, which define the value, material and performance dimensions of educational processes (Kramar, 2009). Learning is most successful when it takes place holistically by activating all domains of the student's learning activity. Strmčnik (2001) defined three basic types of learning activity: motor (kinaesthetic), emotional affective and cognitive (intellectual). Bruner (1966) defines the fields of learning as cognitive, socio-affective and psychomotor. He developed a model of learning at three levels, ranging from concrete experience through visual representations to abstract understanding (ibid.). At the preschool level, the child transitions between the concrete and the visual level.

The ergonomic design of a child's computer use expresses the areas of the child's learning and takes place on a physical, cognitive and organizational level. In the psychomotor field, the ergonomic treatment takes into account the anatomical, anthropological, and psychological characteristics of the child. In the cognitive field, it concerns the influence of computer tools on the child's thought processes and interaction with the computer and other people. At the organizational level, which concerns the socio-affective domain of learning, it takes into account the influence of socio-technical systems and processes (Karwowski, 2005; Volk et al., 2017). For ergonomic study, it is interesting for a child to use different computer interfaces and compare a desktop computer and a laptop. The use of mouse and keyboard takes place on an abstract level. Touch interfaces and tangible interfaces approach the child's manipulation of objects and connect the physically concrete level with the visual display on the screen. Modern technology has passed the first phase of mouse and keyboard, the second phase of touch interfaces. At the current stage of development of object interfaces and the Internet of Things (Wiberg, 2017) it allows ergonomic adaptation to the needs of the child. 
Ivanuš Grmek and Javornik Krečič (2011) define learning activity as a conscious and goal-oriented activity consisting of various psychophysical components, which is a condition for successful child development and learning success. They agree that digital technology should be integrated into early learning and examine which technology to include, ways of integration, and also when the integration of digital technology may be inappropriate. Kindergarten educational technology encompasses both on-screen digital technology and digital technology without screens. Involved in the child's free and in guided play takes place in several ways. Guided play enables adult mediation in the use of digital technology, as described by Livingstone and co-authors (2017) and helps to create the child's area of proximal development (Vygotsky, 1978). The use of digital technology through adult mediation also enables guided discovery learning. The use of digital technology in guided play or guided discovery learning takes into account the high complexity of digital media, supports children's activity and encourages the development of children's skills through various ways of intervening in the use of technology. The central goal of the growing number of didactic digital games is the development of curricular areas designed for different types of play and for different developmental periods of the child.

Children's development is intertwined in the physical, motor, cognitive, emotional and social fields, and change in one area also affects other areas (Videmšek and Pišot, 2007). Movement has a major impact on children's cognitive and psychophysical development (Tomporowski, McCullick, Pendleton and Pesce, 2015). Motor development is embedded in the cultural environment. Cultural and social experiences shape motor behaviour and motor learning, which is related to learning in other areas (Adolph and Hoch, 2019). The child processes external stimuli and perception through his own imagination, vocalization of words or sounds, and motor movement (Singer, 1981). When using a computer, she needs space to move, processes information with movement, and interacts with peers and adults. When using a personal computer static on a desk, the child moves around the computer while using a tablet allows the child to move around the room with the computer. Didactic programs should promote the integration of all areas of learning and eliminate risks to the child's motor development. 
In the cognitive field of learning, the introduction of educational technology is intended for literacy, speech and language development, mathematical literacy and the development of metacognitive skills (Yelland, 2005). In the United States, the National Association for the Education of Young Children (NAEYC) supported the introduction of educational technology in preschool educational institutions as early as 1996 (Rosen and Jaruszewicz, 2009). The treatment of technology integration in early learning has been polarized (Bowman, 1999). Proponents of early science and mathematics introduced educational technology based on the constructivism theories prevalent in the 1990s (Bowman, 1999; Clements, 1999). The principles of implementation emphasized the role of the teacher in choosing the appropriate software, mutual promotion of cognitive and social skills of the child, inclusion of computers in conjunction with traditional early learning materials, inclusion by providing equal opportunities for children, use by overcoming stereotyping of individuals and groups. support for the training and education of teaching staff (Yelland, 2005).

In introducing activities supported by digital technology, these authors point to the need to focus on activities to develop thinking, problem solving, and learning to learn, rather than training. As early as the late 1990s, meaningful learning was introduced in the United States to replace basic skills training without understanding concepts (Bowman, 1999), the use of computers to develop learning and metacognitive skills (Papert, 1980; 1980a), and computer-assisted collaborative learning and training in conjunction with collaborative and competitive tasks, computer visualization, and virtual representations for learning concepts (Clements, 1999).

In the field of speech and language development, digital technology supports storytelling and interactive picture books. The child tells a story while creating, where she combines traditional and digital activities (Istenič Starčič, Cotič, Solomonides and Volk, 2016).

In the field of art, digital technology supports art, music and dance expression. The child uses different materials in artistic expression, experiencing their shape, weight and composition. She draws with her fingers or with tools, and this is also made possible by a tablet computer. The touch interface is more intuitive than a 
computer with a mouse and keyboard, a child can create by exploring natural sensorimotor forms of interaction (Volk et al., 2016). Tangible interfaces also enable the use of objects in interaction with digital content (Istenič Starčič, Cotič and Zajc, 2013).

Alternative interfaces support learning and development in the field of motor development and enable the integration of activities in all areas. In Slovenia, at the beginning of the development of didactic programs, there were many programs that connected areas of learning, such as cognitive and motor for learning mathematics in motion. Movement is an integral part of every child's activity and should also be supported by technology. The computer corner requires sitting in front of a screen and that does not suit a small child. Children prefer to stand and move around the computer. Mobile technology, on the other hand, enables the child to be used ergonomically in motion and in various positions.

- The child learns in a social environment, in a group (Vygotsky, 1987), so it is necessary to enable her to cooperate with peers. The social-affective field of learning is considered as:

- The impact of social interaction and emotions in a child which may encourage or inhibit learning. The teacher encourages social interaction and provides support for self-awareness, social awareness, directs the attention of the child and the group. An important feature of a child's play and learning is the child's attention, which is reflected in independence, creation and motivation in the expressiveness and divergence of his play activity (Ivić, 1981).

- Development of socio-affective skills that include self-awareness, responsible decision-making, social awareness, and relational skills (Dusenbury, Yoder, Dermody and Weissberg, 2020).

The use of digital technology and the Internet in learning in the social-affective field of learning includes the connection of emotions with the use of technology, the expression of emotions in technologically supported social interaction and the development of social-affective skills. The development of social-affective skills in 
technologically supported environments can be hampered. Playing with digital toys diminishes the child's play, as it does not stimulate her imagination and expression of emotions, the child's imagination is replaced by built-in interactive mechanisms, which means that she does not animate her emotions when playing with a digital toy.

The contribution of the teacher in directing social interaction and the individual child in play and learning depends primarily on the teacher's knowledge of the child's reality, which is increasingly composed of interactions in Internet environments using digital equipment. Children's play and interpersonal interactions with adults at an early age change with touch interfaces and digital toys. Teachers and parents need strategies for using digital media and an understanding of the environment that digital technologies create in promoting play-based learning. Studies show that there are risks in the field of social-affective learning and development and in recent decades forms of problematic Internet use and risk factors have been identified.

The teacher plays an important role in the preschool period. In order to be able to adequately support learning and development activities in the social-affective field, she also needs competencies in the field of the impact of digital technologies, related practices and problematic use of the Internet on children's development and learning. Teachers need to be trained in problem areas of Internet use and offered strategies to promote an appropriate socio-affective environment, to develop skills and to reduce risk factors for problematic practices. The teacher can make an important contribution to raising parental awareness. Addressing the socio-affective field of technology-supported development and learning and the problematic use of the Internet also affects the integration of digital technology into early learning.

\section{Planning and monitoring}

Children's play influences the development of social skills, emerging mathematical abilities, the acquisition of early concepts of language literacy and self-regulation (Leong and Bodrova, 2012). Adults follow several criteria when encouraging and guiding (ibid.). The criteria listed by Leong and Bodrova (ibid.), are considered in the context of the inclusion of digital resources: 
- The game plan which expresses the level of the child's ability to plan the game in advance. The teacher works with the children to create a plan, encouraging them with questions to design the theme of the game and the rules. Leading the planning phase can be done by drawing and showing different options and examples of resolving potential conflicts. The teacher can use various programs for graphic display, animation and simulation.

- Role-playing and rules that children express linguistically and emotionally. The teacher shows the children different roles and associated activities in the cause-and-effect relationship.

- The objects the child uses in the game have different levels of realism. The game uses real, symbolic and imaginary objects. The teacher encourages children to expand the repertoire of the use of an individual object by actually or imaginatively transforming and adding functions. Digital characters can be applied and the child can design and re-design or transform them.

- Language involves the child's communication in the game, in the execution of different scenarios and the coordination of mutual activities in the role play. The teacher introduces children to the use of language specific to different professions and social roles by showing examples and different stories using digital resources.

- The script covers children's play themes, including sequences in a play event or story and the interactions between their roles. The extended game monitoring timeframe covers a longer period of time. The course of activities and events that children play covers different stages. Children in the game discuss different topics that they do not always know, and the teacher can introduce them to them by researching on the Internet, using various didactic programs, video or audio podcasts.

The teacher introduces digital technology, taking into account:

- how they are used in support of child's learning and development, taking into account the child's developmental characteristics,

- linking the use of digital technology to traditional activities,

- the diversity of experiences and networking and coordination with children's activities in the family environment, 
- opportunities to play in cooperation and interaction,

- communication between the teacher / parents and the child and between peers, which is important to establish partnership,

- enabling healthy use with awareness of health and ethical factors,

- recognizing boredom and managing feelings of boredom properly by expanding the range of children's interests,

- strengthening self-regulation.

The teacher observes the response, verbal, physical, nonverbal, fine motor, motor, the level of engagement with which the children devote themselves to the task, and the mood of the individual and the group. She monitors and processes activities. The observation of a group and an individual is important for several reasons:

- observing the development of skills,

- intervention that enables the appropriateness of the manner and time of implementation of activities,

- individualization and differentiation to bridge differences between children,

- identification of interests and potential incentives for the development of children's interests,

- analysis of activities and their ease of use, according to the needs, interests and motivation of the child, curricular goals, coherence between boys and girls, age suitability in heterogeneous groups,

- selecting the type and level of intervention, monitoring, support, problem solving, and switching between activities.

For the technology integration, the teacher must be familiar with:

- children's practices in the use of technology in play in a family environment,

- digital screen toys and digital toys without a screen,

- principles of integration of educational technology,

- recommendations of competent organizations,

- research findings at national and international level,

- learning objectives with digital technology by curricular areas and recommended activities, 
- skills and habits of using digital technology of children in a group in cooperation and partnership with parents.

The teacher should plan to integrate digital technology in a series of steps:

- Review what is available in the kindergarten and make a list that includes the categories of tools, the stage of development and the areas of learning. She also looks at what she can get for free on the internet.

- Selects educational technology appropriate to the developmental stage.

- Reviews selected technologies, plans their use and introduces possible adjustments.

- Takes into account the children's skills and the differences in skills between them.

- Plans to include educational technology in relation to the objectives in the curriculum, taking into account didactic principles (for example, according to the principle of individualization, posing challenges to children).

Risk-focusing and delaying closer contact with technology neglects the opportunities of employing digital practices for a child's emerging literacy and for developing learning dispositions. A fundamental challenge to integration is bridging the gap between digital practices as fundamental socio-cultural practices that the child learns through play. Children's digital practices as play enable them to understand cultural practices (Edwards, 2013). Digital toys and programs can also perform the functions of a hidden curriculum. Thus teachers and parents need to critically rethink their content and forms (Edwards, 2015). Research findings show how digital play is present in several ways in all types of child's play. In different types of play, children include characters from popular media productions. They include a computer or parts of a computer (screen, keyboard, mouse) in a role-playing game (where a computer represents a job). The boundaries between traditional and digital play are blurred (Marsh, 2010), and parents and teachers play an important role in promoting a child's digital play (Figure 8). 
Figure 8: The planning factors for digital technology integration

\section{Learning environment design for digital experiences}

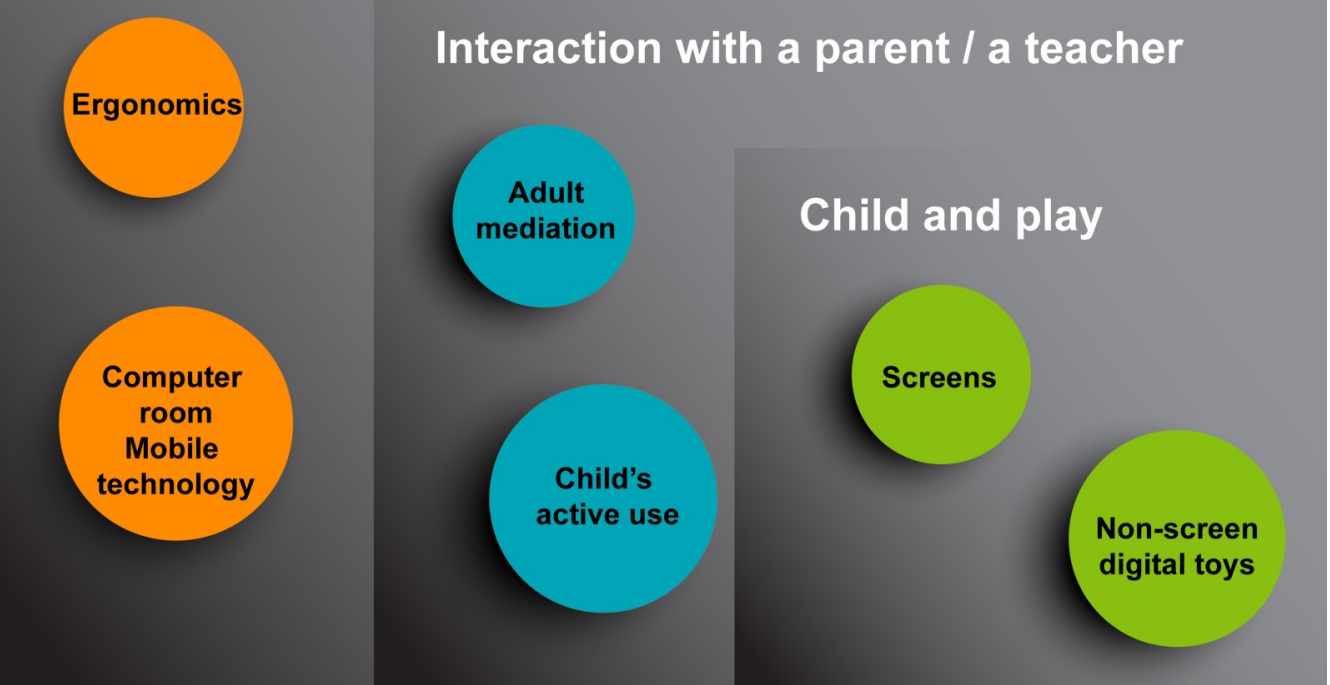




\section{Digital storytelling}

\section{Storytelling as a teaching method and definition of the concept}

Narration is one of the forms of the method of interpretation (Poljak, 1988; Tomić, 1999), which differs from other forms such as description, explanation, elucidation and judgment (Poljak, 1988; Blažič et al., 2003) in that that it concerns the presentation of a fictional or reproductive story with emphasized emotional elements (Tomić, 1999), with a motivational role, tension and attraction to promote emotional engagement (Blažič et al., 2003). Blažič and co-authors define the content characteristics as: appropriate detail, localization, topicality, systematicity, logic and comprehensibility. Storytelling concerns phenomena, events, rules of conduct and ideas. It is used in various fields of science, literature and art (Blažič et al., 2003). The authors distinguish three approaches to storytelling; epic with extensive and detailed narration, lyrical with narration focused on emotional experience, and dramatic narration with a plot (Tomić, 1999; Žagar, 2011). Traditionally didactic, narration was conceived as a mono-directional method in which a teacher or student speaks (Tomić, 1999). In addition to the oral narration of one-person, digital storytelling includes multimodal, interactive communication with the possibility of involving several people.

Narration is defined by (1) narrative genres (characteristics and laws of storytelling within genres) and (2) the process of communication between the narrator and the listener (Zupan Sosič, 2013). Storytelling is also understood as a fundamental way of verbal communication, characteristic of everyday communication. Zupan Sosičeva (ibid., pp. 76) defines storytelling on three levels: as (1) product (story), (2) basic characteristic, form (narrative), (3) procedure and action (narration). It involves the process and relationship (1) between the narrator and the listener, (2) between the mode and object of the narration, and (3) between the narrator and the narrative structure. Based on what has been written, we can define storytelling as a way of communication that is characteristic of everyday communication, various genre messages, as well as educational communication, in the form of a story, by arousing emotional engagement. 


\section{Studying the characteristics of storytelling and inclusion in the curriculum}

Storytelling enables the establishment of meaning and is expressed in "narrative thinking", which Bruner defined as one of two forms of thinking, the narrative and the rational thinking (Bruner, 2004). Narrative is an integral part of perception and interpretation of reality (Zupan Sosič, 2013). Narrative thinking places the individual's thinking, getting to know and learning in the context of motives, intentions, actions and achievements (Marjanovič Umek and Fekonja, 2019, pp. 12). Narrative thinking develops at a very early stage of a child's development and is one of the child's means / tools of learning and establishing a relationship with the environment (Bruner, 1991).

The basic feature of the method of storytelling is fiction (Tomić, 1999). Storytelling harnesses the creative power of the imagination and is the child's basic tool - which the child develops in imaginative play (Vygotsky, 1978). Through storytelling, the child makes sense of and interprets her experiences and views (Ahn and Filipenko, 2007). Developed forms of symbolic play lead to the child's creation in the field of art and language. Marjanovič Umek and Fekonja (2019, pp. 72-77) define children's play, drawing and storytelling as related activities in which the child expresses her understanding of the world. A child's symbolic play with drawing and storytelling is often based on a literary story, and also the group form of symbolic play or socio-dramatic play is performed by children on the basis of a story (ibid.).

The study of storytelling is considered by Zupan Sosičeva (2013, pp. 62-66) in two contexts. Within the descriptive, he treats storytelling as a way of organizing human experience and thinking. This deals with the structural properties of storytelling in the context of a definitive context.

Among the characteristics of the story within the descriptive approach are:

- translatability of the story into different media (oral, written, illustrated, film; written or spoken channel, language, images or gestures; different genres), 
- story as a form of behaviour; the narrator talks about what happened, discovers and invents and interprets,

- constitutes an interpretation into a meaningful whole,

- illuminates timeliness,

- narrative as an integral part of human perception and interpretation of reality,

- the narrative has a cognitive, identity, performative and inventive category. (ibid.)

Within the defining approach, the story is structured by:

- timing of the story (chronological or nonchronological),

- the principle of probability or persuasiveness,

- causal relationships,

- general principles of the event space, the literary person and event (ibid.).

Similarly, Bruner establishes a distinction between the study of storytelling as a means / tool of cognition, presentation, and knowledge creation, and the re-learning of text structure within literary theory (Bruner, 2004). In this book, we do not mention the theory of dramatic or artistic storytelling, which deserves a special attention in the future. The transmedia nature of narration, which is embodied in various art media, literary text, painting, film or dance as a form, deals with the peculiarities of storytelling in various art media forms. In the last two decades, under the influence of Kressa and co-authors (Kress and van Leeuwen, 2001; Kress and Jewitt, 2003) the concept of multimodality involving varied forms of meaning making involving combinations of expression codes, such as images, text, gestures and sound.

Storytelling in the child's early development is associated with the development of speech and cognitive abilities and emerging literacy, so it plays an important role in the preschool curriculum (Marjanovič Umek, Fekonja and Pečjak, 2012; Marjanovič Umek and Fekonja, 2019). Storytelling is an integral part of speech development related to academic literacy (ibid.) and can be oral, written, illustrative, puppet-based, or dramatic. 
Storytelling encompasses general and specific educational objectives. Using various means of expression, the objectives are defined in the field of experience, expression and creativity, development of language skills, spatial representations, visualization, motor skills, development of emotional intelligence, critical thinking and learning about cultural heritage (Curriculum for Art Education (Kocjančič, 2011), and the curriculum for music education (Holcar, 2011), Curriculum for Slovene (Poznanovič Jezeršek, 2018)).

Most curricula mention creativity and critical thinking among the general and specific learning objectives of storytelling. These are in addition to communication and collaboration between learning and innovation competencies (P21, 2010; 2012). Most curricula mention creativity and critical thinking among the general and specific learning objectives of storytelling. These are in addition to communication and collaboration between learning and innovation competencies (Sternberg, 2005). Learning in different storytelling contexts enables creativity as an ability to think (Torrance, 1972), express one's own interest (Yang, 2012), self-actualize (Maslow, 1976), and engage (Joas, 1996).

In the field of education, we have several purposes of storytelling, such as personal stories in the development and reflection of identity, stories for activating different groups, and stories for developing different types of literacy (Istenič Starčič et al., 2016), resolving dilemmas, conflicts, antagonisms, confronting views and resolving mis-concepts. We use different types of story: stories focused on personal experience, fictional stories, historical stories, stories with which we recreate literary and other works of art. We can use different genres when telling stories. Short stories that Gutierrez (2015) rclassifies by story design are often in use: a story based on a case; a story based on a problem; a story based on a script; or a story based on narration. The narrative-based story does not assume the student's active involvement, while the script simulates a reality in which students come to insights based on testing (ibid.). Storytelling takes place in various social forms, in the performance of the teacher, students, or in cooperation between teacher and students using different communication codes. 
Storytelling is established in all disciplinary areas. We have given examples from the curricula of language and literature and the arts, but it is also used in the teach ing of social sciences, mathematics and science, to break down misconceptions and to develop concepts. In an age of rapid progress and scientific discovery, leading scientists are also being trained to use storytelling techniques to explain new scientific discoveries to society (Green, Grorud-Colvert and Mannix, 2018).

In the socio-affective learning domain, through the experience of the story (on an imaginary level or through the experience of one's own or the hero's contextual situation) and through the commitment triggered by the narrator, stories stimulate emotional responses, empathy, identification and social interaction. Learning is encouraged by emotional commitment and the ability of the story to transfer the listener into the world of the story (ibid.).

In the cognitive learning domain, the development of knowledge is enabled by storytelling with the introduction of context, causal connections, presentation of different perspectives and insights (Istenič Starčič et al., 2016; Istenič Starčič, Huang, Valeeva, Latypova, and Huang, 2017). Making sense with a story provides a narrative context that evokes emotional engagement. The narrator learns by telling (a personal story, reflection and narration that pursues pre-defined goals). Listeners learn alternately through the experience of the storyteller (Green, Grorud-Colvert and Mannix, 2018).

Storytelling involves a variety of activities involving different means of expression and the making of meaning. The psychomotor learning domain is perhaps more pronounced in early learning, as the child learns through fine-motor and gross-motor movement. The theory of embodied cognition emphasized the role of motor skills in cognition and learning relevant to all developmental and learning stages. Involving movement through dance, play, puppetry, performance or presentation for different occasions is an integral part of storytelling in different historical periods. 


\section{Approaches and storytelling designs}

Storytelling is a personal interpretation focused on personal experience, whether of the narrator or the listener. Both the narration, the origin of the story and the reception with the communion and the interpretation of the story are personal experiences. The interaction between the narrator and the listener is an integral part of storytelling.

In the educational process, storytelling enables the realization of one of the key objectives of encouraging the motivation and commitment of the student in the personal interpretation of knowledge. Learning takes place through personal thinking in familiar contexts. Narrative thinking allows the context to be established in several ways. The context is established by the narrator-teacher with a story appropriate to the students' developmental stage. The narrator is the student herself, but she can also be a teacher collaborating with a student.

The characteristics and process of storytelling follow the developmental stage of the child. Storytelling in early childhood is associated with the development of a theory of mind in which a child understands her own mental states, such as the desires, intentions, beliefs, and mental states of others. The theory of the mind enables the child to structure the story (Marjanovič Umek and Fekonja, 2019, pp. 14.).

Characteristics of storytelling focused on personal experience (Ochs, 2004):

- It represents the event in a temporal and causal orderliness.

- To achieve narrative attention, the narrator uses an unusual or unexpected or problematic event as the core of the story.

- When presenting a past event or anticipating an imagined event in the future, the narrator organizes the personal experience in a human time perspective.

- The transformation of personal experience into different narrative structures and logics is a distinguishing human characteristic.

- Personal experience can be achieved in two ways (by presenting the unexpected or by exposing the dilemma).

- Use of authentic context. 
- Demonstrate the coherent logic of the event or probe alternative organizations.

- Use of different genres and narrative practices.

- Narration of personal experience in five dimensions (the speaker's personal narratives are co-constructed by narrator and listener, 'tellability' - unordinary or unexpected event, embeddedness - placement in a context relevant to communion by relevant thematic and rhetoric format, linearity, the moral stance.

- Narrative experiences promote self-awareness through the actions, feelings, thinking of the characters.

\section{Features of digital storytelling}

Digital storytelling is widely gaining ground. It takes place using various devices, software and applications. In social networks, storytelling is present in the storyline integrating of online self-presentation, thus developing identity and digital competencies and becoming a way of interaction and expression of young generations. Communication involves a high degree of composition of verbal, visual and other data used and specific to different cultural contexts. The integration of various expression codes: images, sound, video with static and dynamic, linear and spatial presentation supported by modern technologies. Kress and Jewitt study how multi-expression or multimodal texts are included in the curriculum in different subjects and how the nature of learning resources changes as they move away from the printed book in the transition to screen media. Text processing captures multimodal expression and the transition from static text to dynamic visualization and interaction (Kress and Jewitt, 2003).

The pedagogy movement of multiliteracy or compound literacy examines multimodal literacy in the context of young people's cultural practices, which are becoming increasingly digitized and are forming young people's identity (Cope and Kalanski, 2009). Lankshear and Knobel (2006) address changes in print books and textbooks, reading habits, and approaches to new generation learning in the context of digital practices. 
Digital storytelling exploits the potential of technology for multimodal expression, storytelling by combining text, image and other modes. Mayer's theory of multimedia learning encouraged a combination of text and image (Mayer, 2001). Digital technology enables the integration of dynamic visualization.

Digital storytelling enables the situated development of literacy, which is contextualized into reflection and identity, related to digital practices (Istenič Starčič et al., 2016).

- The method of digital storytelling is used in the teacher's professional development and pedagogical work. In professional development, digital storytelling enables reflection and supports the development of professional identity. In pedagogical work, teachers prepare teaching materials, organize student activities in which they acquire and develop their knowledge in various fields. In the education and training of teachers, the method of digital storytelling enables the connected development of competencies in the technological, pedagogical and content-specific subject area. In the initial education of teachers, the author introduced digital storytelling in the 2007/08 academic year in the subject of educational technology in the study programs of preschool education and classroom teaching (ibid.). In developing the competencies of teachers and teachers for the use of educational technology in teaching and learning, two principles formed the basic guideline which endure after more than a decade of preparing future teachers using the method of digital storytelling: (1) co-creation of teacher and child and (2) learning through research, construction and creation, combining traditional and digital resources.

In teaching, digital storytelling requires:

- didactic, content and technological planning of preparation and implementation,

- connecting different learning domains (cognitive, socio-affective and psychomotor),

- the inclusion of the story as a coherent framework for the presentation of facts and their scientific interpretation, 
- linking the verbal and the pictorial, as the image reduces the cognitive load (Mayer, 2001),

- development of digital competencies and multimodal design,

- developing skills in the combination of traditional and digital means and resources for meaning making,

- development of interpersonal skills and empathy (in any storytelling, the contact between the narrator and the listener is crucial),

- developing cooperation and interaction between teacher and students and between students.

Digital storytelling contributes the learning process in several ways. It:

- encourages learning by connecting different learning domains (cognitive, socio-affective and psychomotor),

- enables the establishment of context and relationships in the structure of concepts and phenomena,

- encourages the development of active listening attention and skills,

- encourages the development of language literacy,

- enhances the ability to visualize,

- establishes a context for the development of meaning and self-understanding,

- encourages the development of creativity,

- develops critical thinking,

- encourages the development of problem-solving skills.

\section{Digital storytelling in teaching evolution}

The period of early learning is critical for teaching in the field of evolution. From an early age, a child forms naive notions about nature and living beings that are essentialist and teleological (Kelemen, Emmons, Schillaci and Ganea, 2014). Learning goals in the field of evolution are placed in the curriculum during adolescence, when performances are already consolidated and therefore represent a major barrier to learning. They are difficult to transform and some are preserved even in adulthood. 
It has been found that when reading stories, children are less burdened with representations (Browning and Hohenstein, 2013). Evolution researchers have written imaginative stories for teaching that break down misconceptions and prepare the child to think about phenomena and relationships. Storytelling encourages the child to form her own interpretation of the narrative and draws her into an imaginary world in which she is able to move away from the known and ready for new insights. Therefore, stories can make an important contribution to breaking down misconceptions (Browning and Hohenstein, 2013). The imaginary world and imaginary heroes are not merely part of the imagination, the child engages them more flexibly, for her they can represent reality (Sharon and Woolley, 2004). Children combine imaginary and real world through stories and build reality (Ahn and Filipenko, 2007). The story enables the treatment of concepts adapted to the child's age: it provides a cohesive framework, i.e. a combined treatment of facts and scientific explanation (Kelemen et al., 2014), reduces cognitive load with a picture book and thus takes into account information processing capabilities (Mayer, 2001).

To summarize:

- Storytelling is a child's original way of interacting with the environment and interpreting in developing their own understanding and ideas.

- Storytelling encourages the child to form her own interpretation of the narrative.

- Storytelling draws the child into a fantasy world and allows her to move away from the known and face the unknown. The ability to self-interpret and deviate from one's own notions helps to break down misconceptions (Browning and Hohenstein, 2013).

- The story allows the treatment of concepts adapted to the age of the child.

- The story provides a cohesive framework, ie a connected treatment of facts and scientific interpretation.

- The picture book reduces the cognitive load and thus takes into account the child's ability to process information (Mayer, 2001). 
Deborah Kelemen and her colleagues wrote a story to address the adaptation of organisms by natural selection. She tested it in an experiment in which children between the ages of five and six and between the ages of seven and eight participated. Children's naive notions of adaptation through natural selection are formed from misconceptions consistent with the transformist notion that transformation occurs through adaptation over a lifetime of one generation (Kelemen et al., 2014). Through her experiment, she proved that storytelling with a picture book encouraged an understanding of natural selection and adaptation in accordance with evolutionary theory and prepared children for later learning in the field of evolution. The story establishes a cohesive framework for dealing with scientific findings in presenting and substantiating facts and scientific explanations (ibid.). With a story supported by a picture book, we present the facts in an imaginary context. By telling a story, we encourage the child to think about processes and phenomena, and we also prepare her for the development of complex concepts in his imaginary experience of the world. Among the most widespread examples of stories on the topic of evolution is the story of the Great-grandmother of the fish by Jonathan Tweeta and Karen Lewis (2015), which also includes didactic instructions for use.

Lugmayr and co-authors defined four dimensions of digital storytelling, - narration, perspective, interactivity, medium. Narration is an artifact of storytelling that encourages emotional engagement. It is characterized by causality, temporality (chronological, non-cronological), characters, narrative expression and structure (sequencing and plot), organization (linear, spatial) and interpretation. Perspective expresses the pedagogical function through levels and their combinations: cognitive and emotional, depiction and presentation, and the process of coding and decoding. With technological development, interactivity has become a fundamental component of storytelling. Interactivity involves a commitment to storytelling, computer interaction, and taking decisions about the flow of the story. The medium focuses on technology and technological features, channels, digital contents and modes (Lugmayr, Sutinen, Suhonen, Islas Sedano, Hlavacs and Suero Montero, 2017).

Robin (2008) described seven key elements of digital storytelling: 
- Viewpoint: What is the main point of the story and the author's perspective?

- The dramatic question: A key question of the story that arouses and maintains attention until the end of the story.

- Emotional dimension: Key themes that engage the audience emotionally.

- The gift of narrator's voice: Bringing the story closer to the personal context of the audience.

- Soundtrack: The effect of music and sound accompaniment.

- Economy: A relationship between scale and structure that maintains attention and does not overload.

- Dynamics: Story rhythm or the dynamics and pace of the drama.

Istenič Starčič and co-authors (2016) include the type of story, representational forms, numerical data and context among the components of digital storytelling in learning mathematical arithmetic problems. The evaluation of digital storytelling is based on verbal (narrative cohesion, articulation of a mathematical problem story), visual, spatial, auditory criteria and dynamics (Istenič Starčič et al., 2016).

Chung (2007) described the following steps in digital storytelling: (1) writing, (2) storyboard, (3) production, (4) character making, (5) evaluation. Among the criteria for evaluation, Chung (2007) combines narrative abilities and their realization with multimodal expression and establishing a relationship between audio, video, text, image, effects and their connection into a whole. It is important to harmonize the visual and the auditory according to the purpose; images stimulate thinking, emotions, and expression; the personal voice is crucial element in telling the story (ibid.). 


\section{Abstract}

The book Educational Technology and the Construction of an Authentic Learning Environment at the core of educational technology sets out to improve the performance of the educational process. Educational technology is addressed in the global system of factors of the educational process, as it plays an important role in linking teaching in educational institutions and learning in natural environments. Educational technology enables the establishment of an authentic learning environment in three important ways: (1) the use of digital media is an authentic activity for today's generations, an authentic environment of social life, (2) due to the capabilities of modern technology, authentic learning environments can be established by connecting 'classroom' and various original environments (natural and other) and (3) a 'classroom' with all functions can be established in a variety of original environments. This paper discusses early learning, which is becoming increasingly permeated by digital technology in the primary family environment, affecting the child's relationships, interaction content, and environment, and changing family interaction. According to research reports concern for children's development and learning, triggers polarization, producing both advocates and opponents. Emphasizing the risks and delaying closer contact with technology neglects the opportunities of digital practices for a child's emerging literacy and the development of learning dispositions. A fundamental challenge to inclusion is bridging the gap between digital practices as fundamental socio-cultural practices that the child learns through play. As the boundaries between traditional and digital play are blurred, digital play should also be included in the play-based kindergarten curriculum and a link between home and kindergarten should be established and maintained in partnership with parents. Among the key factors for the integration of educational technology in kindergartens are the attitudes and competencies of pedagogical staff that need to be developed in primary and lifelong learning. This book discuss possibilities for the integration of educational technology the structure of the educational process in terms of learning factors, structural and process factors of learning and subjects of the learning process, teacher and student. In the early 20th century, educational technology took on the role of aids, teaching aids, or resources. Later, under the in- 
fluence of communication theories, it was conceived as a carrier or mediator of information. In both periods, it was included in the didactics among the structural components of the educational process. With the development of computer technology and under the influence of cognitive theories of learning and teaching, the consideration of gadgets has been joined by the consideration of process design and implementation. Educational technology interweaves two aspects: the aspect of using technology as a structural component and the aspect of designing the learning process (process components). This paper discusses the competencies of the 21st century, among which these two aspects form a special set of information, media and technological skills. In modern times, the prevailing discourse in the field of educational technology is the development of digital competencies of the teacher, who succeeded information literacy and a little later media literacy. The beginnings more clearly expressed the notion of autonomous literacy as a set of skills, techniques, and procedures for use in a variety of contexts and situations. Media literacy has already been addressed in social contexts in its beginnings, consistent with the social concept of literacy. The discussion of digital literacy includes two submenus: (1) conceptualization of digital literacy in the process of moving from technological and information practices to social practices and (2) transformation of original literacy with a written medium that transforms into multimodal literacy, and multiliteracy compound literacy in social practices. The book presents the method of digital storytelling, which the author has studied in detail over the years, as an example/case study of good practice. The method of storytelling is an extended form of the method of interpretation included in various areas of the curriculum. Storytelling enables the establishment of meaning, perception and interpretation and is expressed in narrative thinking. Through storytelling, the child makes sense of and presents her experiences and views, and develops narrative thinking. In its digital form, storytelling exploits the potential of technology for multimodal expression and enables the situated development of literacy, contextualized in reflection and an identity that is increasingly associated with digital practices. 


\section{Povzetek}

Delo Izobraževalna tebnologija in izgradnja avtentičnega učnega okolja v jedro izobraževalne tehnologije postavlja izboljšanje uspešnosti vzgojno-izobraževalnega procesa. Izobraževalna tehnologija je obravnavana $\mathrm{v}$ globalnem sistemu dejavnikov vzgojno-izobraževalnega procesa, saj ima pomembno vlogo pri povezovanju poučevanja v vzgojno-izobraževalnih zavodih in učenja v naravnih okoljih. Izobraževalna tehnologija omogoča vzpostavljanje avtentičnega učnega okolja na tri pomembne načine: (1) uporaba digitalnih medijev je za današnje generacije avtentična aktivnost, avtentično okolje socialnega življenja, (2) zaradi zmožnosti sodobne tehnologije se lahko avtentična učna okolja vzpostavljajo s povezovanjem 'učilnice' in različnih izvirnih okolij (naravnih in drugih) in (3) 'učilnica' z vsemi funkcijami se lahko vzpostavi v različnih izvirnih okoljih. $\mathrm{V}$ pričujočem delu je obravnavano zgodnje učenje, ki postaja vse bolj prežeto $\mathrm{z}$ digitalno tehnologijo v primarnem okolju družine, ki posega $v$ razmerje med otrokom, interakcijsko vsebino in okoljem, in spreminja interakcijo v družini. Skrb za otrokov razvoj in učenje, po poročilih raziskav, sproža polarizacijo, zagovornikov in nasprotnikov. Poudarjanje tveganj in odtegovanje tesnejšega stika s tehnologijo zanemarja priložnosti digitalnih praks za otrokovo porajajočo se pismenost in razvoj dispozicij za učenje. Temeljni izziv vključevanju predstavlja premoščanje razkoraka med digitalnimi praksami kot temeljnimi družbeno-kulturnimi praksami, ki jih otrok usvaja z igro. Ker se meje med tradicionalno in digitalno igro brišejo, je treba tudi v kurikulu za vrtce, ki temelji na igri, vključevati digitalno igro in v partnerstvu s starši vzpostavljati in ohranjati vez med domom in vrtcem. Med ključnimi dejavniki za vključevanje izobraževalne tehnologije v vrtce so stališča in kompetence pedagoških delavcev, ki jih je treba razvijati v začetnem in vseživljenjskem izobraževanju. Možnosti za vključevanje izobraževalne tehnologije so preučevane tudi $v$ strukturi vzgojno-izobraževalnega procesa $z$ vidika dejavnikov učenja, strukturnih in procesnih dejavnikov učenja ter subjektov učnega procesa, učitelja in učenca. Na začetku 20. stoletja je izobraževalna tehnologija zajemala vlogo pripomočkov, učil ali sredstev. Pozneje, pod vplivom komunikacijskih teorij, je bila pojmovana kot nosilec ali posredovalec informacij. $\mathrm{V}$ obeh obdobjih je bila v didaktiki vključena med strukturne sestavine vzgojno-izobraževalnega procesa. $Z$ razvojem ra- 
čunalniške tehnologije in pod vplivom kognitivnih teorij učenja in poučevanja se je obravnavi pripomočkov pridružila obravnava načrtovanja in izvajanja procesov. Izobraževalna tehnologija prepleta dva vidika: vidik rabe tehnologije kot strukturne sestavine in vidik oblikovanja učnega procesa (procesne sestavine). V širšem okviru so obravnavane kompetence 21. stoletja, med katerimi tvorijo poseben sklop informacijske, medijske in tehnološke kompetence. $\mathrm{V}$ sodobnosti je na področju izobraževalne tehnologije prevladujoči diskurz razvoj digitalnih kompetenc učitelja, ki je nasledil informacijsko pismenost in malce poznejšo medijsko pismenost. Začetki so izraziteje izražali pojmovanje avtonomne pismenosti kot set spretnosti, tehnik in postopkov za uporabo v različnih kontekstih in situacijah. Medijska pismenost je bila že v svojih začetkih obravnavana v socialnih kontekstih, skladna s socialnim konceptom pismenosti. Obravnava digitalne pismenosti zajema dve podmeni: (1) konceptualizacijo digitalne pismenosti v procesu odmika od tehnološkega in informacijskega $\mathrm{k}$ socialnim praksam in (2) transformacijo izvirne pismenosti z medijem pisave, ki se transformira $v$ večkodno pismenost, in večrazsežnostno pismenost - sestavljeno pismenost $\mathrm{v}$ socialnih praksah. $\mathrm{V}$ primerih dobre prakse je predstavljena metoda digitalnega pripovedovanja zgodb, ki sem jo $\mathrm{v}$ preteklih letih podrobno preučevala. Metoda pripovedovanja zgodb je razširjena oblika metode razlage, vključena na različnih področjih kurikula. Pripovedovanje zgodb omogoča vzpostavljanje smisla, percepcije in razlage in se izraža v pripovednem mišljenju. Otrok s pripovedovanjem osmišlja in predstavlja svoje izkušnje in poglede ter razvija pripovedno mišljenje. V svoji digitalni obliki pripovedovanje zgodb izkorišča potencial tehnologije za večkodno izražanje in omogoča umeščen razvoj pismenosti, kontekstualiziran v refleksiji in identiteti, ki je vse bolj povezana z digitalnimi praksami. 


\section{Author index}

A

AAP (American Academy of Pediatrics) 32, 41, 48, 48

Adams Becker, S.

Adolph, K. E.

6

Akyempong, $\mathrm{K}$.

Alasuutari, M.

5

Ananthanarayanan, V.

46

Anderson, C. A.

6

Anderson, D. R.

50

Anderson, R. H.

31,48

20

Aufderheide, P.

10

Australian Gov. Department of Health 49

B

Bagon, Š.

Bahovec, E. D.

52,55

Ball, S.

24

Bandura, A.

31,50

Barr, D.

5

Barr, R.

24

Batistič Zorec, M.

44

Bawden, D.

9, 10

Behrens, S. J.

9, 10

Bekelman, T. A.

45

Bellows, L. L.

45,50

Berčnik, S.

44

Bird, J.

39, 39, 56, 59

Blažič, M.

Bleakley, A.

$1,3,18,55,71$

33

Bodrova, E.

Bogatz, G. A.

39, 56, 66, 67

24

Bolstad, R.

36

Bonte, $\mathrm{S}$.

33,34

Bovaird, J. A.

44

Bowman, B. T.

64

Bronfenbrenner, U.

23, 42, 46, 58

Brown, J.

58

Browning, E.

80

Bruce, B. C.

$6,8,22,23$ 
Bruner, J.

$62,72,73$

Buckingham, D.

$8,10,11$

C

Canadian Pediatric Soc. Dig. Health TF 48

Cerbin, W.

Chakroff, J. L.

33,40

Chamberlin, B.

45

Chaudron, S.

Cheung, C. K.

$40,41,43,51$

Christie, J. F.

5

Chung. S. K.

39,50

Clark, L. S.

82

Clark, L.

45

Clements, D. H.

$25,30,32,33$

Clinton, K.

7, 64

Cohen, A. A.

11

Conery, L.

24

Cook, D. T.

5

Cope, B.

24,31

8,77

Cotič, $\mathrm{M}$.

$41,64,65$

Council of Australian Governments

49,54

Cummins, M.

6

D

Danby, S. $\quad 34$

Davis, A. 6

Davis, F. D. 13

Davis, G. B. 13

Debevc, M. 11, 59

Dermody, C. 65

Devjak, T. 44

Dewey, J. 6, 22

Dill, K. E. $\quad 50$

Donham, J. O. 10

Drent, M. 13

Driscoll, M. 18

Dusenbury, L. $\quad 65$

Dwyer, F. 8 
E

Eastin, M. S. 32

Edwards, C. P. $\quad 44$

Edwards, R. 38, 39, 54, 56, 59, 69

Edwards, S.

$26,31,34,38,39,56,69$

Ely, D. P.

$18,19,28$

Emmons, N. A. $\quad 79$

Erstad, O.

Ertmer, P. A.

$8,10,11,27$

12

F

Fadel, C.

4

Fekonja, U.

Fisser, P.

$53,72,73,74,76$

Flewitt, R.

Folkvord, F. 8

$8,10,11,27$

32

Freeman, A.

6

Freitas, L. 58

Friederich, L.

24

G

Ganea, P. A. $\quad 79$

Gentile, D. A. $\quad 50$

Gilster, P. 10

Golinkoff, R. M. 52

Green, S. J. $\quad 32$

Greenberg, B. $\quad 32$

Grizzle, A. 5

Grorud-Colvert, K. $\quad 75$

Grosman, M. 11, 12

Gross, J. F. 10

Guernsey, L. $\quad 30$

Gulden, T. 26

Gutierrez, K. $\quad 74$

$\mathrm{H}$

Haight, P. L. $\quad 24$

Hall Giesinger, C. 6

Hannafin, M. J. 20 
Hannon, P. 11

Hao, Y. 6

Harrison, J. 5

Hassinger-Das, B. $\quad 52$

Hattie, J. 6

Hatzigianni. M. 12

Hauptman, S. $\quad 59$

Hayne, $\mathrm{H}$. 24

Heitink, M. 8

Helsper, E. $\quad 32$

Hinske, S. $\quad 37$

Hirsch, E. 32

Hirsh-Pasek, K. 52

Hobbs, R. 9

Hoch, J. E. 63

Hofshire, L. 32

Hohenstein, J. $\quad 80$

Holcar, A. $\quad 74$

Holzinger, A. 59

Howard-Jones, P. $\quad 50$

Huang, P. S. $\quad 75$

Huang, Y. M. $\quad 75$

Hughes, C. E. 37, 38

Huston, A. C. 24

Hutt, C. $\quad 59,60$

I

Ilgaz, $\mathrm{H}$. $\quad 52,53$

Islas Sedano, K. 81

Issroff, $\mathrm{K}$. 1

Istenič Starčič, A. $\quad 6,12,13,23,28,41,47,58,59,64,65,74$, $75,78,82$

Ivanuš Grmek, M. $\quad 1,55,63$

Ivić, I. 53, 65

$\mathrm{J}$

Jakku-Sihvonen, R. 13

Jaruszewicz, C. 48, 58, 64 
Javornik Krečič, M.

55, 63

Jenkins, $\mathrm{H}$.

11, 26, 146

Jewitt, C.

77

Jewitt, C.

73

Joas, $\mathrm{H}$.

74

Johnson, D. W.

6

Johnson, J. E.

39,50

Johnson, R. T.

6

Johnson, S. L.

45

Jones, A.

K

Kalaitzidis, I.

12

Kalantzis, M.

8

Kalaš, I.

Karila, K.

46

Karwowski,W.

62

Kelemen, D.

$79,80,81$

Kirkup, G.

20

Kirkwood, A.

20

Kittredge, A. K. 52

Klahr, D.

52

Klembas, A.

59

Knobel, N.

12,77

Knoche, L. L.

44

Kocjančič, N. F.

74

Koehler, M. J.

14

Koh, J. H. L.

5

Koole, M.

14

Kopp, B.

15

Koschmann, T.

6

Kožuh, I.

11, 59

Kramar, M.

1,3

Kress, G.

$11,73,77$

Kroflič, R.

52,53

Kumar, K. L.

59

Kupzyk, K. A.

44 
L

Lampe, M. $\quad 37$

Lampert, C. $\quad 40,41$

Land, S. $\quad 20$

Lander, K. 11, 27

Langhorne, M. J. 10

Lankshear, C. $\quad 12,77$

Lapuh, J. B. 59

Latypova, L. A. $\quad 75$

Lebeničnik, M. 6, 12, 13, 23, 28, 59

Lee, K. S. $\quad 6$

Leong, D. 39, 56, 66, 67

Lešnik Musek, P. 61

Levin, J. A. 6, 8, 22, 23

Lewis, K. 81

Lewis, M. $\quad 8,11$

Lindon, J. $\quad 36,61$

Livingstone, S. 32, 33, 34, 46, 47, 63

Lugmayr, A. 81

Lull, J. $\quad 32$

Lupiáñez-Villanueva, F. $\quad 32$

Lye, S., Y. 5

$\mathrm{M}$

Maccoby, E. E. $\quad 32$

Mannix, H. $\quad 75$

Marentič Požarnik, B. 13

Marjanovič Umek L. 36, 52, 53, 61, 72, 73, 76

Marsh, J.

$8,10,11,26,27,38,42,43,70$

Mascheroni, G. 33

Maslow, A. H. $\quad 74$

Mayer, R. E. $\quad 78$

McCloskey, M. $\quad 45$

McCullick, B. 63

McPack, J. 59, 60

Means, B. 6

Meelissan, M. 13

Michnick Golinkoff, R. $\quad 52$ 
Miguel, $\mathrm{H}$.

Mikkola, A.

Mishra, P.

Moore, D.

8

Morley, D. 32

Morris, M. G.

Moura, A. A.

$\mathrm{N}$

Nastasi, B. K.

Nathanson, A. I.

Niemi, $H$.

Norwich, B.

$\mathrm{O}$

Ochs, E.

76

Ólafsson, K.

32,33

Oliver, K. M.

20

Olson, K.

6

Opara, B.

58

Ortner, S.

23

Ottenbreit-Leftwich, A. T.

12

Owston, R.

$\mathrm{P}$

P21(Partnership for 21st Ctr. Skills) 4, 8, 74

Papert, S.

5,64

Pečjak, S.

73

Pempek, T. A.

31,48

Pendleton, D. M.

Pereira, A. F.

49

Pesce, C.

63

Piaget, J.

$5,35,59,60$

Pišot, R.

63

Plowman, L.

$3,12,24,26,27,30,33,34,36,40,41,43$, $54,58,59$

Poljak, V.

71

Potter, W. J. 
Poznanovič Jezeršek, M.

74

Puentedura, R. R.

Purushothm, R.

$\mathrm{R}$

Ragan, T. J.

Romiszowski, A. J.

Rautio, P.

Redecker, C.

Rehmke, D.

Reiser, A. R.

Resman, M.

Resnick, L. B.

Reynolds, A.

Rice, $M$.

Rideout, V.

Ristimaki, E.

Ritchie, L.

Robb, M.

Robin, B. R.

Robinson, A.:

Rosanda, V.

Rosen, D. B.

Rots, I.

Rowntree, D.

Russo, C. E.

$\mathrm{S}$

Sadik, O.

Sefton-Green, J.

Sendurur, E.

Sendurur, P.

Serra, J.

Sharon, T.

Sheehy, K. M.

Sheridan, S. M.

Siddiq, F.

Silverstone, R.
19

12

13, 14

11

20

35

17

10

1, 2, 3, 18, 19, 28

44

6

20

24

45

13

8

$24,30,31,32$

81

11

58

48, 58

33, 34

1

33

$8,10,11,27$

12

12

49

80

11, 27

44

6

32 
Singer, D. G.

Smirnova, E.

Smith, P. L.

Solomon, G.

Solomonides, I.

Spencer, M.

Stahl, G.

Stephen, C.

Sternberg, R.

Straker, L.

Straub, E. T.

Street, B.

Strijker, A.

Strmčnik, F.

Strouse, G. A.

Suero Montero, C.

Suhonen, J.

Süss, D.

Suthers, D.

Sutinen, E.

Swaminathan, S.

$\check{S}$

Šilih, G.

Šorgo, A.

$\mathrm{T}$

Tearle, P.

The New London Group

Thompson, D. A.

Thorpe, K.

Tissari, V.

Toličič, I.

Tomić, A.

Tomporowski, P. D.

Tondeur, J.

Torrance, E. P.

Trilling, B.
25, 31, 50, 63

$39,50,56$

19

24

64

8

6

$3,12,26,33,34,36$

74

$34,48,49,50$

59

$7,8,9$

8

$1,6,21,55,56,62$

33

81

81

40, 41

6

81

7

55

11

13

12

45

34

13

36

71,72

63

6,13

74

4 
Troseth, G. L.

Tuazon, R.

Tudge, J.

Turk, Ž.

Turnšek, T.

Tweet, J.

$\mathrm{V}$

Vaala, S. E. 33

Valcke, M.

$13,33,34$

Valeeva, R. A.

75

Valenčič Zuljan, M.

13

van Braak, J.

6

van Leeuwen, $T$.

Veltri, G.

Venkatesh, V.

Victoria state gov. Educ, and training 20

Videmšek, M.

63

Vigotski, L. S.

$7,15,25,25,35,36,52,53,63$

Volk, M. $41,62,64,65$

Vukan, M.

W

W3C Web Accessibility Initiative $\quad 58,59$

Wartella, E.

Weigel, $\mathrm{M}$.

Weisberg, D. S.

52,53

Weiss, J.

Weissberg, $\mathrm{R}$ 65

Wener, B. 33,34

Wiberg, M. 62

Wijnen, C. W. 40, 41

Wilson, C. 5

Wing, J. M. 5

Wohlwend, K. 54

Woolley, J. D. 80

Wright, J. C. 
Y

Yang, Y. F.

74

Yelland, N.

64

Yilmaz, R. M.

37

Yoder, N.

65

Z

Zabatiero, J.

34

Zajc, M.

41, 65

Zupan Sosič, A.

71, 72

$\check{Z}$

Žagar, D.

71 


\section{Subject index}

audiovisual communication $6,18-19,50,55$

authentic learning 8,22

cognitive theory $2-3,19$

communication theory $2-3,18$

competence 4-9, 12-16, 34, 37, 58, 67, 75-85

computer-assisted collaboration 4-6, 20, 47, 65

constructivism 6,20

didactic principle $55-59,70$

didactics $1-3,15,18,20,27-28,36-39,46,48,52-59,64-70,72,79,82,85$

digital storytelling $2,72-83$

digital technology $3,11,13,22-29,30-34,35-54,63-70,79$

ecological systems theory 23,58

educational technology $1-8,12,18-29,34,52-59,62-79$

ergonomic 41, 62- 66

information communication technology $1-4,13,20,30,32,44,58$

internet 5-6, 7, 9-12, 20, 34, 32, 34, 37, 41, 51, 58, 62-67

internet of toys 37

learning activity $9,18,55-63$ 
learning domains $6,60,62,75,78-79$

learning environment 5-6, 12, 20-21, 28-29, 37, 53, 57-59

learning objective $19,29,49,54,62-66,69,74$

literacy $4-17,27,33,37,40,42,46,52,54,64,70,73-85$

parental mediation $25,28,32-34,40-42$

partnership 3, 42-47

play $3,6-715-16,22-28,30-4048-50,52-71$

preschool 3, 12-13, 15-16, 22, 33-34, 36, 38-49, 52-58, 62, 66, 74, 78

socio-cultural theory $23,25-26,59$

teaching methods $6,19,28,71-79$

theory of instruction 1, 19-18, 28

theory of learning $1,18-19$

toy $3,15,26-29,27-32,36-39,47-54,62,66,69-70$

zoone of proximal development 4, 15, 30, 35, 53, 64 


\section{References}

(American Academy of Pediatrics) committee on public education. (1999). Media education. Pediatrics, 104(2), 341-343. Pridobljeno:

https://pediatrics.aappublications.org/content/104/2/341

AAP (American Academy of Pediatric) committee on public education. (2010). Policy statement - media education. Pediatrics. Pridobljeno:

https://pediatrics.aappublications.org/content/pediatrics/early/2010/09/27/peds.20101636.full.pdf

AAP (American Academy of Pediatrics) committee on public education. (2011). Media use by children younger than two years. Pediatrics. Pridobljeno: https://pediatrics.aappublications.org/content/pediatrics/128/5/1040.full.pdf

AAP (American Academy of Pediatrics) committee on public education. (2016). Council on Communications and Media. Media and young minds. Pediatrics. Pridobljeno: https://pediatrics.aappublications.org/content/pediatrics/138/5/e20162591.full.pdf

Adams Becker, S., Cummins, M., Davis, A., Freeman, A., Hall Giesinger, C., and Ananthanarayanan, In. (2017). NMC Horizon Report: 2017 Higher Education Edition. Austin, TX, USA: The New Media Consortium.

Adolph, K. E., and Hoch, J. E. (2019). Motor Development: Embodied, Embedded, Enculturated, and Enabling. Annual Review of Psychology, 70, 141-64.

Anderson, C. A., Gentile, D. A., and Dill, K. E. (2012). Prosocial, Antisocial, and Other Effects of Recreational Video Games. Chapter in D. G. Singer in J. L. Singer (Ur.), Handbook of Children and the Media, 2nd Edition, 249-272. Thousand Oaks, CA: Sage.

Anderson, D. R., and Pempek, T. A. (2005). Television and very young children. American Behavioral Scientist, 48(5), 505-522.

Aufderheide, P. (1992). Media Literacy: A Report of the National Leadership Conference on Media Literacy. Queenstown Maryland: The Aspen Institute Wye Center.

Australian Children's Education and Care Quality Authority. (2015). Using digital touch technologies to support children's learning. Pridobljeno: https://wehearyou.acecqa.gov.au/2015/07/15/using-digital-touch-technologies-to-supportchildrens-learning/

Australian Government Department of Health. (2012). Inactivity and screen time. Pridobljeno: http://www.health.gov.au/internet/publications/publishing.nsf/Content/gug-indig$h b \sim$ inactivitiy 
Bahovec, E. D., et al. (1999). Kurikulum za vrtce. Ljubljana. Ministrstvo za šolstvo in šport, Zavod Republike Slovenije za šolstvo.

Ball, S., and Bogatz, G. A. (1970). The first year of Sesame Street: An evaluation. Princeton, NJ: Education Testing Service.

Bandura, A. (1977). Social learning theory. New York: General Learning Press.

Barr, D., Harrison, J., and Conery, L. (2011). Computational Thinking: A Digital Age Skill for Everyone. Learning \& Leading with Technology, 38(6), 20-23.

Barr, R., in Hayne, H. (1999). Developmental Changes in Imitation from Television during Infancy. Child Development, 70(5), 1067-1081.

Batistič Zorec, M., and Turnšek, T. (2002). Posredna raven. V: L. Marjanovič Umek, U. Fekonja, T. Kavčič in A. Poljanšek: Ravni, področja in kazalci kakovosti predšolske vzgoje v vrtcu (Ur.) Kakovost v vrtcih, 44-48. Ljubljana: ZIFF.

Bawden, D. (2001). Information and digital literacies; a review of concepts. Journal of Documentation, 57(2), 218-259.

Behrens, S. J. (1994). A conceptual analysis and historical overview of information literacy. College and Research Libraries, 55(4), 309-322.

Bellows, L. L., McCloskey, M., Clark, L., Thompson, D. A., Bekelman, T. A., Chamberlin, B., in Johnson, S. L. (2018). HEROs: Design of a Mixed-Methods Formative Research Phase for an Ecocultural Intervention to Promote Healthy Eating and Activity Behaviors in Rural Families With Preschoolers. Journal of Nutrition Education and Behavior, 50(7), 736-745.

Berčnik, S., and Devjak, T. (2017). Sodelovanje med starši in vzgojitelji v različnih konceptih predšolke vzgoje. CEPS journal, 7(4), 208-226.

Berners-Lee, T. (1997). »World Wide Web Consortium (W3C) Launches International Web Accessibility Initiative."Web Accessibility Initiative (WAI). Accessed June 19, 2010. http://www.w3.org/Press/WAI-Launch.html

Bird, J., and Edwards, S. (2015). Children learning to use technologies through play: A Digital Play Framework. British Journal of Educational Technology, 46(6), 1149-1160.

Blažič, M., Ivanuš Grmek, M., Kramar, M., and Strmčnik, F. (2003). Didaktika. Novo mesto: Visokošolsko središče Novo mesto.

Bolstad, R. (2004). The Role and Potential of ICT in Early Childhood Education: A Review of New Zealand and International Literature. Wellington: Ministry of Education. Pridobljeno: https://www.nzcer.org.nz/system/files/ictinecefinal.pdf

Bowman, B. T. (1999). Dialogue on early childhood science, mathematics and technology education a context for learning: Policy implications for math, science, and 
technology in early childhood education. Pridobljeno:

http://www.project2061.org/publications/earlychild/online/context/bowman.htm

Bronfenbrenner, U. (1979). The ecology of human development: experimentsby nature and design. Cambridge, Massachusetts, London, England: Harvard University Press.

Bronfenbrenner, U. (1986). Ecology of the Family as a Context for Human Development: Research Perspectives. Developmental Psychology 22(6), 723-742.

Browning, E., and Hohenstein, J. (2013). The use of narrative to promote primary school children's understanding of evolution. Education 3-13: International Journal of Primary Elementary and Early Years Education, 2, 1-18.

Bruce, B. C., and Levin, J. A. (1997). Educational technology: Media for inquiry, communication, construction, and expression. Journal of Educational Computing Research, 17(1), 79-102.

Bruce, C. (1997). The Seven Faces of Information Literacy Adelaide: Auslib Press.

Bruner, J. (1977). The process of education. Cambridge: Harvard University Press.

Bruner, J. (1991). The Narrative Construction of Reality, Critical Inquiry 18(1), $1-21$.

Bruner, J. (2002). Making Stories: Law, Literature, Life. Cambridge in London: Harvard University Press.

Bruner, J. (2004). Life as Narrative. Social Research, 71(3), 691-710.

Bruner, J. S. (1966). Toward a theory of instruction. Cambridge, MA: Harvard University Press.

Buckingham, D. (2015). Defining digital literacy. What do young people need to know about digital media? Nordic Journal of Digital Literacy, 4, 21-34.

Canadian Paediatric Society Digital Health Task Force. (2017). Screen time and young children: promoting health and development in a digital world. Paediatr Child Health 22, 461-468.

Cerbin, W., and Kopp, B. (2006). Lesson Study as a Model for Building Pedagogical Knowledge and Improving Teaching. International Journal of Teaching and Learning in Higher Education, 18(3), 250-257.

Chakroff, J. L., and Nathanson, A. I. (2008). Parent and school interventions: Mediation and media literacy. V: S. L. Calvert in B. J. Wilson (Ur.), The handbook of children, media, and development, 552-576. West Sussex, UK: Blackwell.

Chaudron, S. (2015). JCR Science and Policy reports, Young children (0-8) and Digital Technology. A qualitative exploratory study across seven countries. Luxembourg: Joint research centre \& Institute for protection and security of children. 
Chung. S. K. (2007). Art Education Technology: Digital Storytelling. Art Education, 60(2), 17-22.

Clark, L. S. (2011). Parental Mediation Theory for the Digital Age. Communication Theory, 21, 323-343.

Clements, D. H. (1999). Young children and technology. In dialogue on early childhood science, mathematics, and technology education. Washington, DC: American Association for the Advancement of Science.

Clements, D. H., Nastasi, B. K., and Swaminathan, S. (1993). Young children and computers: Crossroads and Directions from Research. Young Children, 48(2), 56-64.

'Competency' Merriam-Webster's Collegiate Dictionary, 2020. Accessed https://www.merriam-webster.com/dictionary/competency

Cook, D. T. (2005). The Dichotomous Child in and of Commercial Culture. Childhood 12(2), 155-9.

Cope, B., and Kalantzis, M. (2009). »Multiliteracies«: New Literacies, New Learning, Pedagogies: An International Journal, 4(3), 164-195.

Council of Australian Governments. (2009). Belonging, Being \& Becoming: The Early Years. Learning Framework for Australia. Canberra: Commonwealth of Australia. Pridobljeno:

https://www.acecqa.gov.au/sites/default/files/2018-02/belonging_being_and_becoming_t he_early_years_learning_framework_for_australia.pdf

Davis, F. D. (1989). Perceived Usefulness, Perceived Ease of Use, and User Acceptance of Information Technology. MIS Quarterly, 13(3), 319-340.

Debevc, M., Kožuh, I., Hauptman, S., Klembas, A., Lapuh, J. B., and Holzinger, A. (2015) Using WCAG 2.0 and Heuristic Evaluation to Evaluate Accessibility in Educational Web Based Pages. V: D. Liberona, T. Welzer-Družovec (Ur.), Learning Technology for Education in Cloud. LTEC 2015. Communications in Computer and Information Science, 533, 197-270. Cham: Springer.

Debevc, M., Weiss, J., Šorgo, A., and Kožuh, I. (2020). Solfeggio learning and the influence of a mobile application based on visual, auditory and tactile modalities. British Journal of Educational Technology, 51(1), 177-193.

Dewey, J. (1938). Experience in education. New York: Collier Books.

Dewey, J. (1943). The child and the curriculum: The school and society. Chicago: University of Chicago Press.

Drent, M., and Meelissan, M. (2008). Which factors obstruct or stimulate teacher educators to use ICT innovatively? Computers \& Education 51(1), 187-199.

Driscoll, M. (2000). Psychology of Learning for Instruction. Needham Heights, MA: Allyn \& Bacon. 
Dusenbury, L., Yoder, N., Dermody, C., and Weissberg, R. (2020). An Examination of K-12 SEL Learning Competencies/Standards in 18 States. Pridobljeno: https://casel.org/wp-content/uploads/2020/03/CSI-Frameworks.pdf

Eastin, M. S., Greenberg, B., and Hofshire, L. (2006). Parenting the Internet. Journal of Communication, 56, 486-504.

Edwards, R. (2015). Software and the hidden curriculum in digital education, Pedagogy, Culture \& Society, 23(2), 265-279.

Edwards, S. (2013). Digital play in the early years: a contextual response to the problem of integrating technologies and play-based pedagogies in the early childhood curriculum. European Early Childhood Education Research Journal, 21(2), 199-212.

Ely, D. P. (1983). The definition of educational technology: An emerging stability. Educational Consideration, 10(2), 2-4.

Ertmer, P. A., Ottenbreit-Leftwich, A. T., Sadik, O., Sendurur, E., and Sendurur, P. (2012). Teacher beliefs and technology integration practices: A critical relationship. Computers \& Education, 59(2), 423-435.

Fekonja, U. (2001). Igrače. V: L. Marjanovič Umek in M. Zupančič (Ur.) Psihologija otroške igre. Razprave Filozofske fakultete. 85-106. Ljubljana: Znanstveni inštitut Filozofske fakultete.

Fetler, M. (1985). Sex differences on the California statewide assessment of computer literacy. Sex Roles, 13, 181-191.

Fisser, P., Heitink, M., and Strijker, A. (2020). Authentic integration of Digital Literacy in education: development of a new curriculum and assessment tool. $V: D$. Schmidt-Crawford (Ur.), Proceedings of Society for Information Technology \& Teacher Education International Conference (pp. 1205-1215). Online: Association for the Advancement of Computing in Education (AACE). Pridobljeno:

https://www.learntechlib.org/primary/p/215886/

Gilster, P. (1997). Digital literacy. New York: John Wiley.

Green, S. J., Grorud-Colvert, K., and Mannix, H. (2018). Uniting science and stories: Perspectives on the value of storytelling for communicating science. FACETS 3 , 164-173.

Greenleaf, R. K. (2003). Motion and emotion. Principal Leadership, 3(9), 14-19.

Grosman, M. (2011). Večrazsežna pismenost izziv sedanjosti. V: M. Cotič, V. Medved Udovič in S. Starc (Ur.), Razvijanje različnih pismenosti, 19-27. Koper: Univerzitetna založba Annales.

Guernsey, L. (2012). Screen time: How electronic media - from baby videos to educational software - affects your young child. Philadelphia, PA: Basic Books. 
Gulden, T. (2015). A system analysis of transmedia storytelling toys in relation to desire and pleasure. Procedia Manufacturing, 3, 2071-2078.

Gutierrez, K. (2015). Keep eLearning Real: 4 Basic Story Types to Link Learning to the Real-World. Pridobljeno: https://www.shiftelearning.com/blog/keep-elearning-real-4basic-story-types-to-link-learning-to-the-real-world

Hannafin, M. J., Land, S., in Oliver, K. M. (1999). Open learning environments: Foundations, methods, and models. V: C. Reigeluth (Ur.), 254 Instructional-design theories and models: Volume II (115-140). 255 Mahwah: Lawrence Erlbaum.

Hao, Y., and Lee, K. S. (2017). Inquiry of pre-service teachers' concern about integrating Web 2.0 into instruction. European Journal of Teacher Education, 40(2), 191-209.

Hattie, J. (2009). Visible learning: A synthesis of meta-analyses relating to achievement. New York, NY, USA: Routledge.

Hatzigianni. M., and Kalaitzidis, I. (2018). Early childhood educators' attitudes and beliefs around the use of touchscreen technologies by children under three years of age. British Journal of Educational Technology, 49(5), 883-895.

Hobbs, R. (2011). The State of Media Literacy: A Response to Potter. Journal of Broadcasting \& Electronic Media, 55(3), 419-430.

Hobbs, R. (2017). Approaches to teacher professional development in digital media literacy education. V: B. De Abreu, P. Mihailidis, A. Lee, J. Melki in J. McDougall (Ur.), International Handbook of Media Literacy Education, 88-113. New York: Routledge.

Holcar, A. (2011). Učni načrt program osnovna šola, glasbena vzgoja. Ljubljana: Ministrstvo za šolstvo in šport, Zavod RS za šolstvo. Pridobljeno: http://www.mizs.gov.si/ fileadmin/mizs.gov.si/pageuploads/podrocje/os/prenovljeni_UN/UN_glasbena_vzgoja.pdf

Howard-Jones, P. (2011). The impact of digital technologies on human wellbeing. Evidence from the science of mind and brain. Oxford, England: Nominet Trust.

Huston, A. C., and Wright, J. C. (1983). Children's processing of television: The informative function of formal features. V: J. Bryant in D. R. Anderson (Ur.) Children's understanding of television, 35-68. New York: Academic Press.

Hutt, C. (1966). Exploration and play in children. Paper presented at the Symposium of the Zoological Society of London, London, England.

Ilgaz, H., Hassinger-Das, B., Hirsh-Pasek, K., and Michnick Golinkoff, R. (2018). Making the Case for Playful Learning. V: M. Fleer, B. van Oers (Ur.), International Handbook of Early Childhood Education, Springer International Handbooks of Education. Cham: Springer Nature Switzerland AG.

Issroff, K., and Scanlon, E. (2002). Educational Technology: The influence of theory. Journal of Interactive Media in Education, 6, 1-13. 
Istenič Starčič, A. (2019). Tehnološko, pedagoško in vsebinsko znanje učitelja ter kurikulum: prispevek na mednarodni znanstveni konferenci Vloga predmetnih didaktik za kompetence prihodnosti, Pedagoška fakulteta Univerze v Mariboru, 4. oktober 2019.

Istenič Starčič, A., and Bagon, $\breve{S}$. (2014). ICT-supported learning for inclusion of people with special needs: Review of seven educational technology journals, 1970-2011. British Journal of educational technology, 45(2), 202-230.

Istenič Starčič, A., Cotič, M., Solomonides, I., and Volk, M. (2016). Engaging preservice primary and preprimary school teachers indigital storytelling for the teaching and learning of mathematics. British Journal of Educational technology, 47(1), 29-50.

Istenič Starčič, A., Huang, P. S., Valeeva, R. A., Latypova, L. A., and Huang, Y. M. (2017). Digital storytelling and mobile learning: potentials for internationalization of higher education curriculum. V: T. C. Huang, R. Lau, Y. M. Huang, M. Spaniol, C. H. Yuen (Ur.) SETE 2017. LNCS, 10676, 400-406. Cham: Springer.

Istenič Starčič, A., and Lebeničnik, M. (2020). Examining the contemporary digital divide of university students with specific reference to students with special educational needs. British Journal of Educational technology, 1-20.

Istenič Starčič, A., and Lebeničnik, M. (2020). Investigation of university students' perceptions of their educators as role models and designers of digitalized curricula. Human technology, 16(1), 55-91.

Istenič Starčič, A., and Turk, Ž. (2016). Ubiquitous learning and digital literacy practices connecting teacher and learner. V: WWW'16 Companion: Proceedings of the 25th International Conference Companion on World Wide Web, 823-827. New York, NY, USA: ACM Digital Library.

Istenič Starčič, A., and Vukan, M. (2019). Teachers' Perception of Data-Driven School Ecosystem and Data Analytics. V: Proceedings of IC4E 2019 (IC4E 2019). Tokyo: Association for Computer Machinery.

Ivanuš Grmek, M., and Javornik Krečič, M. (2011). Osnove didaktike. Maribor: Univerza v Mariboru Pedagoška fakulteta.

Ivić, I. (1981). Igra deteta i njena uloga u razvoju (Zbornik radova 5). Beograd: PA za obrazovanje vaspitačapredškolskih ustanova.

Jenkins, H. (2003). Transmedia Storytelling. Moving characters from books to films to video games can make them stronger and more compelling. MIT Technology Review. Pridobljeno: https://www.technologyreview.com/2003/01/15/234540/transmediastorytelling/

Jenkins, H., Clinton, K., Purushothm, R., Robinson, A., and Weigel, M. (2007). Confronting the challenges of participatory culture: Media education for the 21st century. Chicago IL: The John D. and Catherine T. MacArthur Foundation. 
Joas, H. (1996). The creativity of action. Cambridge, Oxford: Polity Press.

Johnson, D. W., and Johnson, R. T. (1996). Cooperation and the Use of Technology. In D. H. Jonassen (Ed.), Handbook of research on educational communications and technology (1017-1044). New York: Macmillan.

Johnson, J. E., and Christie, J. F. (2009). Play and digital media. Computers in schools, 26(4), 284-289.

Jones, A., Kirkup, G., and Kirkwood, A. (1992). Personal computers for distance education. London: Paul Chapman.

Kalaš, I. (2010). Recognizing the potential of ICT in early childhood education. Analytical survey. Russia: UNESCO Institute for Information Technologies in Education. Pridobljeno: https://unesdoc.unesco.org/ark:/48223/pf0000156769

Karila, K., and Alasuutari, M. (2012). Drawing Partnership on Paper: How do the Forms for Individual Educational Plans Frame Parent - Teacher Relationship? International Journal about Parents in Education, 6(1), 15-27.

Karwowski, W. (2005). Ergonomics and human factors: The paradigms for science, engineering, design, technology and management of human-compatible systems. Ergonomics, 48(5), 436-463.

Kelemen, D., Emmons, N. A., Schillaci, R. S., and Ganea, P. A. (2014). Young children can be taught basic natural selection using a picture-storybook intervention. Psychological Science, 25, 893-902.

Kocjančič, N. F. (2011). Učni načrt program osnovna šola, likovna vzgoja. Ljubljana: Ministrstvo za šolstvo in šport, Zavod RS za šolstvo. Pridobljeno: http://www2.arnes.si/ soppnova/Glavni_okvir/UN_likovna_vzgoja_OS_23-marec2011.pdf

Koole, M. (2009). A model for framing mobile learning. V: M. Ally (Ur.), Mobile learning: Transforming the delivery of education \& training, 25-47. Athabasca: $A U$ Press.

Kramar, M. (2009). Pouk. Nova Gorica: Educa.

Kress, G., and Jewitt, C. (2003). Introduction. V: J. Jewitt \& G. Kress (Eds), Multimodal literacy, 1-18. New York: Peter Lang.

Kress, G., and van Leeuwen, T. (2001). Multimodal discourse: The modes and Media of contemporary communication. London: Arnold.

Kumar, K. L., and Owston, R. (2016). Evaluating e-learning accessibility by automated and student-centered methods. Education Technology Research and Development, 64, 263-283. 
Lampe, M., and Hinske, S. (2007). Integrating interactive learning experiences into augmented toy environments. Proceedings of the workshop on pervasive learning 2007, 1-9. Toronto.

Lander, K., and Sheehy, K. M. (2004). Spatializing literacy research and practice. New York: Peter Lang.

Langhorne, M. J., Donham, J. O., Gross, J. F., and Rehmke, D. (1989). Teaching with computers: a new menu for the '90s. USA: The Oryx Press.

Lankshear, C., and Knobel, M. (2008). New literacies: Everyday practices and clasroom learning (Second edition). Berkshire, England, New York: Open University Press, McGraw-Hill.

Lankshear, C., and Knobel, M. (2011). New literacies, Everyday practices and social learning (Third edition): Berkshire, England, New York: Open University Press, McGraw-Hill.

Lankshear, C., and Knobel, N. (2008). Introduction: Digital literacies: Concepts, policies and practices. V: C. Lankshear in N. Knobel (Ur.) Digital literacies: Concepts, policies and practices. New York, Berlin, Oxford: Peter Lang.

Leong, D., and Bodrova, E. (2012). Assessing and Scaffolding Make-Believe Play. Young Children, 67(1), 28-34.

Lindon, J. (2001). Understanding children's play. Cheltenham: Nelson Thornes Ltd.

Livingstone, S., Ólafsson, K., Helsper, E., Lupiáñez-Villanueva, F., Veltri, G., in Folkvord, F. (2017). Maximizing opportunities and minimizing risks for children online: The role of digital skills in emerging strategies of parental mediation. Journal of Communication, 67(1), 82-105.

Lugmayr, A., Sutinen, E., Suhonen, J., Islas Sedano, K., Hlavacs, H., and Suero Montero, C. (2017). Serious storytelling - a first definition and review. Multimedia Tools and Applications, 76, 15707-15733.

Lull, J. (1980). The social uses of television. Human Communication Research, 6(3), 197-209.

Lye, S., Y., and Koh, J. H. L. (2014). Review on teaching and learning of computational thinking through programming: What is next for K-12? Computers in Human Behavior, 41, 51-61.

Maccoby, E. E. (1951). Television: its impact on school children. The public opinion Quarterly, 15(3), 421-444.

Marjanovič Umek, L. and Kroflič, R. (2009). Predšolska vzgoja v vrtcu (Uvodv tematski številki). Sodobna pedagogika, 3, 6-8.

Marjanovič Umek, L., and Fekonja, U. (2019). Zgodbe otrok: Razvoj in spodbujanje pripovedovanja. Ljubljana: Razprave Filozofske fakultete. 
Marjanovič Umek, L., Fekonja, U., and Pečjak, S. (2012). Govor in branje otrok: Ocenjevanje in spodbujanje. Ljubljana: ZIFF.

Marjanovič Umek, L., and Lešnik Musek, P. (1999). Otrokov razvoj in učenje v simbolni igri. Psihološka obzorja, 98(1), 25-48.

Marsh, J. (2010). Young Children's Play in Online Virtual Worlds. Journal of Early Childhood Research 8(1), 23-29.

Marsh, J., Hannon, P., Lewis, M., and Ritchie, L. (2017). Young Children's Initiation into Family Literacy Practices in the Digital Age. Journal of Early Childhood Research, 15(1) 47-60.

Mascheroni, G., and Ólafsson, K. (2014). Net Children Go Mobile: Risks and opportunities (2. izd.). Milano: Educatt, Net Children Go Mobile. Pridobljeno: http://netchildrengomobile.eu/reports

Maslow, A. H. (1976). The farther reaches of human nature. An Esalen book. Harmondsworth: Penguin Books. McMillan, S. (1996). Literacy and computer literacy: definitions and comparisons. Computers and education, 27(3-4), 161-170.

Mayer, R. E. (2001). Multimedia learning. Cambridge University Press.

Means, B., and Olson, K. (1995). Technology's role in educational reform. Findings from a National Study of Innovating Schools. Washington, DC: Office of Educational Research and Improvement U.S. Department of Education. Pridobljeno: https://www2.ed.gov/PDFDocs/techrole.pdf

Mishra, P., in Koehler, M. J. (2006). Technological Pedagogical Content Knowledge: A new framework for teacher knowledge. Teachers College Record. 108(6), 1017-1054.

Moore, D., and Dwyer, F. (1994). Visual Literacy: A Spectrum of Visual Learning. Englewood Cliffs, NJ: Educational Technology Publications.

Nathanson, A. I. (2002). The unintended effects of parental mediation of television on adolescents. Media Psychology, 4(3), 207-230.

NAEYC (The National Association for the Education of Young Children) (1996). Technology and children 3 through 8: A position statement of the National Association for the Education of Young Children. Washington, DC: NAEYC.

NAYEC (The National Association for the Education of Young Children) (2012). Technology and Interactive Media as Tools in Early Childhood Programs Serving Children from Birth through Age 8. Washington, DC: NAEYC.

Norwich, B. (2008). Dilemmas of difference, inclusion and disability. Abingdon: Routledge.

Ochs, E. (2004). Narrative lessons. In Alessandro Duranti (ed.), A companion to linguistic anthropology, 269-89. Malden, MA: Blackwell. 
Opara, B. (2005). Otroci s posebnimi potrebami v vrtcih in šolah: Vloga in naloga vrtcev in šol pri vzgoji in izobraževanju otrok s posebnimi potrebami. Ljubljana: Center Kontura.

Ortner, S. (1984). Theory in Anthropology since the Sixties. Comparative Studies in Society and History, 26(1), 126-166.

Papert, S. (1980). Teaching children thinking: Teaching children to be mathematicians vs. teaching about mathematics. In The computer in the school: Tutor, tool, tutee, ed. R. Taylor, 161-196. New York: Teachers College Press.

Papert, S. (1980a). Mindstorms: children, computers, and powerful ideas New York: Basic Books.

Partnership for 21st Century Skills (P21) \& American Association of Colleges of Teacher Education (AACTE). (2010). 21st century knowledge and skills in educator preparation [White paper]. Pridobljeno:

http://www.p21.org/storage/documents/aacte_p21_whitepaper2010.pdf

Partnership for 21st Century Skills (P21). (2012). Learn for the 21st century: A report and mile guide for 21 st century skills. Pridobljeno: http://www.p21.org/storage/documents/P21_Report.pdf

Piaget, J. (1962). Play, dreams and imitation in childhood. New York: W. W. Norton.

Plowman, L. (2016). Rethinking context: Digital technologies and children's everyday lives, Children's Geographies, 14(2), 190-202.

Plowman, L., McPack, J., and Stephen, C. (2012). Extending opportunities for learning. The role of digital media in early learning. V: S. Suggate in E. Reese (Ur), Contemporary debates in childhood education and development, 95-104. New York, Canada: Routledge.

Plowman, L., McPake, J., and Stephen, C. (2008). Just picking it up? Young children learning with technology at home. Cambridge Journal of Education, 38, 303319.

Plowman, L., McPake, J., and Stephen, C. (2011). The technologisation of childhood? Young children and technology in the home. Children \& Society, 24(1), 6374.

Plowman, L., Stephen, C., and McPake, J. (2010). Growing Up with Technology: Young children learning in a digital world. London: Routledge.

Plowman, L., Stephen, C., and McPake, J. (2010a). Supporting young children's learning with technology at home and in preschool. Research Papers in Education, 25(1), 93-113.

Poljak, V. (1988). Didaktika. Zagreb: Školska knjiga. 
Potter, W. J. (1998). Media literacy. Thousand Oaks, CA: Sage.

Poznanovič Jezeršek, M. (2018). Učni načrt (posodobljena izdaja). Program osnovna šola. Slovenščina. Ljubljana: Ministrstvo za šolstvo in šport; Zavod RS za šolstvo. Pridobljeno: https://www.gov.si/assets/ministrstva/MIZS/Dokumenti/Osnovnasola/Ucni-nacrti/obvezni/UN_slovenscina.pdf

Puentedura, R. R. (2013). SAMR: Moving from enhancement to transformation. Pridobljeno:

http://www.hippasus.com/rrpweblog/archives/2013/05/29/SAMREnhancementToTransfor mation.pdf

Romiszowski, A. J. (1988). The selection and use of instructional media. For improved classroom teaching and for individualized instruction. (2. izd.). London; Kogan page, New York: Nichols Publishing.

Rautio, P. (2013). Children who Carry Stones in Their Pockets: On Autotelic Material Practices in Everyday Life. Children's Geographies, 11(4), 394-408.

Redecker, C. (2017). European Framework for the Digital Competence of Educators. Luxembourg: Publications Office of the European Union.

Reiser, A. R., in Ely, D. P. (1997). The field of educational technology as reflected through its definition Educational Technology Research and Development, 45(3), 63-72.

Reiser, R. A. (2001a). A history of instructional design and technology: Part I: A history of instructional media. Educational Technology Research and Development, 49(1), 53-64.

Reiser, R. A. (2001b). A history of instructional design and technology: Part II: A history of instructional design. Educational Technology Research and Development, 49(1), 57-67.

Resman, M. (1992). Obrati v »filozofiji« sodelovanja med šolo in domom. Sodobna pedagogika, 43(1-2), 28-39.

Resnick, L. B. (1993). Shared cognition: Thinking as social practice. V: Perspectives on socially shared cognition L. B. Resnick, J. M. Levine, S. D. Tealsey (Ur.). Washington: American Psychology Association.

Reynolds, A., and Anderson, R. H. (1992). Selecting and developing media for instruction. New York: Van Nostrand Reinhold.

Rice, M., and Haight, P. L. (1986). »Motherese " of Mr. Rogers: A description of the dialogue of educational television programs. Journal of Speech and Hearing Disorders, 51, 282-287.

Rideout, V. (2011). Zero to eight: Children's media use in America. San Francisco: Common Sense Media. Pridobljeno:

file:///C:/Users/astarcic/Downloads/zerotoeightfinal2011.pdf 
Ristimaki, E., Niemi, H., Tissari, V., Mikkola, A., and Jakku-Sihvonen, R. (2006). Promoting the Pedagogical Use of ICT in Finnish Universities and Teacher Education Programmes. V: R. Jakku-Sihvonen, H. Niemi, (Ur.), Research-Based Teacher Education in Finland: Reflection by Finnish Teacher Educators, 123-150. Turku: Finnish Educational Research Association.

Robin, B. R. (2008). Digital Storytelling: A Powerful Technology Tool for the 21st Century Classroom. Theory Into Practice, 47(3), 220-228.

Rosanda, V., and Istenič Starčič, A. (2019). A review of social robots in classrooms emerging educational technology and teacher education. Education and selfdevelopment, 14(3), 93-106.

Rosen, D. B., and Jaruszewicz, C. (2009) Developmentally Appropriate Technology Use and Early Childhood Teacher Education, Journal of Early Childhood Teacher Education, 30(2), 162-171.

Rowntree, D. (1982). Educational Technology in Curriculum Development. London: Harper and Row.

Sang, G., Valcke, M., van Braak, J., and Tondeur, J. (2010). Student teachers' thinking processes and ICT integration: predictors of prospective teaching behaviors with educational technology. Computers \& Education, 54, 103-112.

Sefton-Green, J., Marsh, J., Erstad, O., and Flewitt, R. (2016). Establishing a research Agenda for the Digital Literacy Practices of Young Children. A White paper for COST action IS 1410. Pridobljeno:

http://digilitey.eu/wp-content/uploads/2015/09/DigiLitEYWP.pdf

Serra, J., Miguel, H., Moura, A. A., Sampaio, A., and Pereira, A. F. (2020). The effect of play task on maternal touch patterns when interacting with their 12 months-old infants: An exploratory study. Infant Behavior and Development. Dostopno:

https://doi.org/10.1016/j.infbeh.2020.101438

Sharon, T., and Woolley, J. D. (2004). Do Monsters Dream? Young Children's Understanding of the Fantasy/Reality Distinction. British Journal of Developmental Psychology, 22 (2), 293-310.

Sheridan, S. M., Knoche, L. L., Edwards, C. P., Bovaird, J. A., and Kupzyk, K. A. (2010). Parent engagement and school readiness: Effects of the Getting Ready intervention on preschool children's social-emotional competencies. Early Education \& Development, 21(1), 125-156.

Silverstone, R., Hirsch, E., and Morley, D. (1991). Listening to a long conversation: An ethnographic approach to the study of information and communication technologies in the home. Cultural Studies, 5(2), 204-227.

Singer, J. L., and Singer, D. G. (1981). Television, Imagination, and Aggression: A Study of Preschoolers. London, New York: Routledge. 
Smirnova, E. (2011). Character toys as psychological tools. International Journal of Early Years Education, 19(1), 35-43.

Smith, P. L., and Ragan, T. J. (2000). The impact of R.M. Gagne's Work on Instructional Theory. In Richey, R.C. (Ur.), The legacy of Robert M. Gagne (129-163). Syracuse, NY: RIC Clearinghouse on Information and Technology.

'Skill' Merriam-Webster's Collegiate Dictionary, 2020. Accessed https://www.merriam-webster.com/dictionary/skill

Solomon, G., and Cohen, A. A. (1977). Television Formats, Mastery of Mental Skills, and the Acquisition of Knowledge. Journal of Educational Psychology, 69(5), 612-9. $442-53$.

Spencer, M. (1986). Emergent literacies: a site for analysis. Language Arts, 63(5),

Stahl, G., Koschmann, T., and Suthers, D. (2006). Computer-supported collaborative learning: An historical perspective. V: R. K. Sawyer (Ur.), Cambridge handbook of the learning sciences (409-426). Cambridge, UK: Cambridge University Press. Pridobljeno: http://gerrystahl.net/cscl/CSCL_English.pdf

Stapleton, C. B., and Hughes, C. E. (2003). Interactive imagination: Tapping the emotions through interactive story for compelling simulations. IEEE Computer Graphics and Applications, 23(5), 11-15.

Stein, A., in Friederich, L. (1975). Impact of television on children and youth. V: E. M. Hetherington (Ur.). Review of child development research, 5, 183-256. Chicago: University of Chicago Press.

Stephen, C., and Plowman, L. (2014). Digital Play. V: L. Brooker, M. Blaise, S. Edwards (Ur.). SAGE Handbook of Play and Learning in Early Childhood, 330-341. London: SAGE.

Sternberg, R. (2005). Creativity or creativities. International Journal of HumanComputer Studies, 63(4-5), 370-382.

Straker, L., Zabatiero, J., Danby, S., Thorpe, K., and Edwards, S. (2018). Conflicting Guidelines on Young Children's Screen Time and Use of Digital Technology Create Policy and Practice Dilemmas. The Journal of Pediatrics, 2002, 300-303.

Straub, E. T. (2009). Understanding technology adoption: Theory and future directions for informal learning. Review of Educational Research, 79(2), 625-649.

Street, B. (1989). Literacy in theory and practice. Cambridge, New York, Port Chester, Melbourne, Sydney: Cambridge University Press.

Street, B. (2005). Understanding and defining literacy. Background paper prepared for the Education for All Global Monitoring Report 2006. Literacy for Life. UNESCO. Pridobljeno: https://unesdoc.unesco.org/ark:/48223/pf0000146186 
Strmčnik, F. (1987). Sodobna šola v luči učne diferenciacije in individualizacije. Ljubljana: Zveza organizacij za tehnično kulturo Slovenije.

Strmčnik, F. (2001). Didaktika. Osrednje teoretične teme. Ljubljana: Znanstveni inštitut Filozofske fakultete.

Süss, D., Lampert, C., and Wijnen, C. W. (2009). Medienpädagogik: ein Studienbuch zur Einführung. Springer.

Šilih, G. (1961). Očrt splošne didaktike. Ljubljana: Državna založba Slovenije.

Šilih, G. (1970). Didaktika. Ljubljana: Državna založba Slovenije.

The New London Group. (2000). A pedagogy of multiliteracies: designing social futres. V: B. Cope in M. Kalantzis (Ur.). Multiliteracies: literacy learning and the design of social futures, 3-37. London: Routledge.

Toličič, I. (1961). Otroka spoznamo v igri. Ljubljana: DZS.

Tomić, A. (1999). Izbrana poglavja iz didaktike. Ljubljana: CPI Filozofska fakulteta.

Tomporowski, P. D., McCullick, B., Pendleton, D. M., and Pesce, C. (2015). Exercise and children's cognition: The role of exercise characteristics and a place for metacognition. Journal of Sport and Health Science, 4, 47-55.

Tondeur, J., van Braak, J., Siddiq, F., and Scherer, R. (2016). Time for a new approach to prepare future teachers for educational technology use: Its meaning and measurement. Computers \& Education, 94, 134-150.

Torrance, E. P. (1972). Predictive validity of the Torrance Tests of Creative Thinking. Journal of Creative Behavior, 6(4), 236-252.

Trilling, B., in Fadel, C. (2009). 21st Century Skills: Learning for Life in Our Times, San Francisco: CA: Jossey-Bass.

Troseth, G. L., Russo, C. E., and Strouse, G. A. (2016). What's next for research on young children's interactive media? Journal of Children and Media, 10, 54-62.

Tudge, J., Brown, J., and Freitas, L. (2011). The Cultural Ecology of Play: Methodological Considerations for Studying Play in its Everyday Contexts. In: A. Pellegrini (Ur.) Oxford Handbook of the Development of Play, 119-37. Oxford: Oxford University Press.

Tweet, J., and Lewis, K. (2015). Grandmother fish. A child's first book of Evolution. New York: Feiweland friends.

Vaala, S. E., and Bleakley, A. (2015) Monitoring, Mediating, and Modeling: Parental Influence on Adolescent Computer and Internet Use in the United States. Journal of Children and Media, 9(1), 40-57. 
Valcke, M., Bonte, S., Wener, B., and Rots, I. (2010). Internet parenting styles and the impact on internet use of primary school children. Computers \& Education, 55(2), 454-464.

Valenčič Zuljan, M., and Marentič Požarnik, B. (2014). Induction and Early-career Support of Teachers in Europe. European journal of education, 49(2), 192-205.

van Braak, J., and Tearle, P. (2007). The computer attributes for learning scale (CALS) among university students: Scale development and relationship with actual computer use for learning. Computers in Human Behavior, 23(6), 2966-2982.

Venkatesh, V., Morris, M. G., Davis, G. B., and Davis, F. D. (2003). User Acceptance of Information Technology: Toward a Unified View MIS Quarterly, 27(3), 425-478.

Victoria state government Education and training. (2019). Pridobljeno: https://www.education.vic.gov.au/school/teachers/teachingresources/digital/Pages/ teach.aspx

Videmšek, M., and Pišot, R. (2007). Šport za najmlajše. Ljubljana: Fakulteta za šport.

Vigotski, L. S. (1978). Mind and society. The development of higher psychological process. Cambridge, Massachusetts, London, England: Harvard University Press.

Volk, M., Cotič, M., Zajc, M., and Istenič Starčič, A. (2018). Tablet-based crosscurricular maths vs. traditional maths classroom practice for higher-order learning outcomes. Computers \& Education, 114, 1-23.

W3C Web Accessibility Initiative - WAI. (1997). Dostopno: https://www.w3.org/WAI/fundamentals/accessibility-usability-inclusion/

Wartella, E., and Robb, M. (2011). Historical and Recurring Concerns about children's use of the mass media. V: S. L. Calvert in B. J. Wilson (Ur.), The handbook of children, media, and development, 7-26. West Sussex, UK: Blackwell.

Weissberg, D. S., Hirsh-Pasek, K., Golinkoff, R. M., Kittredge, A. K., and Klahr, D. (2016). Guided Play: Principles and Practices. Current Directions in Psychological Science 25(3) 177-182.

Wiberg, M. (2017). The materiality of interaction. Notes on the materials of interaction design. Cambridge, Massachusetts, London, England: The MIT Press.

Wilson, C., Grizzle, A., Tuazon, R., Akyempong, K., and Cheung, C. K. (2013). Media and information literacy curriculum for teachers. UNESCO. Pridobljeno: http://www.unesco.org/new/fileadmin/MULTIMEDIA/HQ/CI/CI/pdf/media_and_informat ion_literacy_curriculum_for_teachers_en.pdf $33-35$.

Wing, J. M. (2006). Computational thinking, Communications of the ACM, 49(3), 
Wing, J. M. (2008). Computational thinking and thinking about computing. Philosophical Transactions of the Royal Society A Mathematical, Physical and Engineering Sciences. 366(1881), 3717-3725.

Wohlwend, K. (2010). A is for Avatar: Young Children in Literacy 2.0 Worlds and Literacy 1.0 Schools. Language Arts, 88(2), 144-152.

Yang, Y. F. (2012). Multimodal composing in digital storytelling. Computers and Composition, 29(3), 221-238.

Yelland, N. (2005). The future is now: A review of the literature on the use of computers in early childhood education (1994-2004). AACE Journal, 13(3), 201-232.

Yilmaz, R. M. (2016). Educational magic toys developed with augmented reality technology for early childhood education, Computers in Human Behavior 54, 240-248.

Zupan Sosič, A. (2013). Zgodba, pripoved in pripovedovanje v dvoravninski in troravninski koncepciji pripovedi. Primerjalna književnost, 36(3), 61-83.

Žagar, D. (2011). Didaktika psihologije v srednjem izobraževanju. Ljubljana ZIFF. 


\section{Review - Martin Kramar}

Dr. Andreja Istenič in her work Educational Technology and the Construction of Authentic Learning Environments discusses the position and role of today's, modern educational technology in the education process.

The work covers addressing the following issues:

- educational technology for the development of 21 st century competencies,

- educational technology in the education process: in the global system and the direct educational process,

- the child's primary environment and digital technology,

- educational technology in structuring the educational environment,

- digital storytelling.

The discussion of individual issues and findings is based on knowledge of didactic theory and the use of educational technology in educational practice in developed countries and on the author's own experience gained through work of teachers' educator.

In the introductory part, she briefly presented the emergence and integration of resources from educational technology into educational practice. She points out an important developmental shift. The means of educational technology in the education process were originally only didactic means (aids) in support of the implementation of lessons. They were also treated in this way by didactic theory. With the development of both educational technology resources and teaching and didactic theory, educational technology has become one of the constitutive factors of teaching, which in today's (modern) educational practices has an increasingly important role at the level of conceptualization and articulation of education processes. With the development of new functions and capacities of modern means of information and communication technology, their function and role in the development of educational processes is also increasing. These are evolving and changing more and more consistently with the development of educational technology. This is also influenced by the increasing use of ICT tools (information and communication technologies) in people's lives and work. ICT resources are also an important constant factor 
in the life and work of children of all ages, developmental stages or levels of upbrin ging and education. However, its use is not limited to activities related to the educational process in kindergartens and schools, but is much wider, more diverse and permanent. Therefore, competences for living and working in current and especially in future developed societies, which are triggered by the increasing and regular use of ICT resources and their development, are increasingly coming to the fore.

The author of the paper emphasizes that educational technology resources are able to perform more and more learning activities (and other related activities), which in the past were performed only by teachers or pedagogical workers. They trigger and open different views on the organization and course of learning, on the didactic systems of the education process and also on the education process in kindergarten. Views (and notions) about the literacy of today's man, the issues of interpersonal relationships, leadership and self-leadership of students are opening up and expanding.

In connection with this or as a result, new phenomena, problems and issues arise, which these funds alone, without pedagogical workers, cannot carry out or solve.

The author emphasizes that educational technology encourages and participates in the development of competencies for the 21st century, especially the third set of competencies. These are information, media and technological competences. Among these, communication, information and media computer and ICT literacy are important from the point of view of educational technology. ICT contributes a great deal to the development of these and its role is indispensable.

The author presented the role and importance of digital and media literacy. She drew attention to the widespread notion and content of literacy in today's developed societies, which is no longer just alphabetical, but increasingly multimodal. Children and students learn about and master digital text creation. This is also necessary, as digital literacy is becoming more widespread and an increasingly important factor - a condition and achievement - already in early learning, in school and further, not only school, education.

The author states that ICT resources (broader than educational technology) affect all areas and the entire child's life and work at home. Thus, they also directly 
and indirectly influence personal development, and there can also be many controversial, problematic and harmful influences. The author points out that ICT resources bring and trigger various phenomena in the home living environment that have a detrimental effect on the health, physical and mental development of children. It is necessary to know this, to be aware of various risks and to take into account the recommendations made by experts on the basis of empirical experience, by observing and researching practice. The work also contains recommendations to be considered in the relationships and use of ICT resources.

In the section educational technology in the educational process, the author IT illuminates with didactic theoretical definitions and structuring of the educational process. She adds that in today's modern educational processes, educational technology is one of the main factors, an important link between the subjects and the structural and process components of this process. To a large extent, it enables the individualization of the process or the individual work of students.

She presented the didactic principles that must be considered when integrating educational technology into the education process. She also explained the relationship between educational technology and toys and how educational technology should be considered in the planning and preparation of the direct education process.

She concludes her work with a chapter on digital storytelling. In it, she highlighted digital storytelling and presented digital storytelling through a concrete case.

The work also contains an extensive rich list of the latest relevant literature, which contains findings of various theoretical scientific studies and (latest) empirical research in this field or issue.

\section{Summary}

Prof. dr. Andreje Istenič Starčič in her work Educational Technology and the Construction of Authentic Learning Environments discusses the position, role and important aspects of the use of educational technology in learning and more broadly in the education process. The author emphasizes that the development of human competencies for the 21 st century is closely related to this. She draws particular 
attention to the modern notion of literacy and the dissemination of its content. This is increasingly multimodal and covers communication, information, media and computer literacy.

She presented new, different, notions of the position, role and importance of educational technology in the education process. Educational technology is no longer just a set of learning aids (tools), but a web of important actors who have increasingly important constitutive, conceptual, operational-executive and developmental function in the education process.

She emphasized that educational technology is an important set of factors in the entire authentic life, not only learning, environment and with a constant presence in all areas of life and work of children, it also constantly influences the learning, development and socialization processes of children and people. The author also draws attention to the appearance of various disturbing and harmful influences on the entire child's development. She also added recommendations for actions that can be taken to reduce, prevent or even eliminate harmful phenomena and their impact.

She concluded her work by showing the implementation of new insights on the use of IT in early learning and digital storytelling.

The work is an important contribution to the theory that sheds light on the position, functions and roles of educational technology in the improvement, modernization and development of new, different didactic approaches and processes in educational practice. It also draws attention to the broader frameworks and aspects of the impact of educational technology in the wider human authentic living environment.

The work is largely based on the international context and comparable relevant reference foreign works. It is an important contribution to this and suitable for international dissemination and for translation into foreign languages.

By showing an example of digital storytelling, it is also a good incentive for modernization and the development of direct practice. 


\section{Review - Matjaž Debevc}

Based on a thorough review, analysis and assessment of the final material for the scientific monograph entitled 'Educational technology and the construction of authentic learning environments', I give a global review assessment.

Given the global application of technologies in everyday life and especially in education, where teachers have to adapt to changes in practice, the scientific monograph by dr. Andreja Istenič.

The main goal of the present scientific monograph is the importance and role of educational technology in the function of the education process, while researching the trends and influences of parents in the child's personal development during the education process. In doing so, she researches and highlights didactic-methodological principles in the use of educational technologies and, at the implementation level, highlights the method of digital storytelling with the help of educational technologies.

With such a scientific approach, structure, effective illustrations, graphs, presentations and the use of appropriate concepts and laws, the author, dr. Andreja Istenič, created scientifically in-depth theoretical text on educational technology, which will certainly help students, teachers, counselors and decision-makers in educational institutions.

When studying and reading the content chapters, it is evident that the author, on the basis of external scientific findings, derived her own findings in the field of educational technologies and teaching methods. The text also shows a rich knowledge of this field, especially from a scientific point of view, as it shows a very good knowledge of current theories and scientific findings in the field of didactics and educational technology, which can only be gained through many years of international experience.

In a professionally consistent and recognizable way, she presents her own findings with a properly structured argument, which she builds in the next, beautifully 
recognizable structure 'meaning - use - contextualisation in space and environment - implementation'.

She substantiates the importance of educational technology with the fundamental function of educational technology in promoting the success of the educational process, which is realized in connecting the school and family environment. She scientifically substantiates the capabilities of modern technology in the establishment of authentic learning environments, where she presents and substantiates authentic activities, the characteristics of the learning and family environment and takes into account the characteristics of the participants in the learning process.

The author further presents the key historical development aspects of the field of educational technology and how the changes have changed the school-family relationship. The author then scientifically substantiates how educational technology has transcended the role of a structural component of the educational process. She highlighted the discussion of the planning and implementation of pedagogical processes with regard to the development of computer technology together with the influence of cognitive theories of learning and teaching.

The author justified the use of educational technology in the context of the competencies of the 21st century and in the context of the basic competencies of educators and teachers. This highlighted the development of definitions of digital competencies of a teacher who inherited information and media literacy.

In her work, the author defends the transcendence of concepts in the context of autonomous literacy and the necessity of treatment in social contexts. The discussion of digital literacy builds on two sub-assumptions: on the conceptualization of digital literacy in the process of moving from technological and information to social practices and on the transformation of original literacy, which is transformed into multidimensional literacy in social practices.

Furthermore, in her work, the author places educational technology in the broader context of child development. It shows how the educator monitors and plans the child's digital practices in partnership with the parents and finds out how the boundaries between traditional and digital play are blurred. It also presents how di- 
gital play in the preschool period as a culturally located activity is the basis for planning didactic-methodological approaches in kindergarten.

At the last, performing, level, the author completes her work by presenting the method of digital storytelling. The presented content on digital storytelling is an interesting example of the use of educational technology, which captures the technological aspect with its production and presentation of the story, as well as all the didactic features of analog, conventional, traditional storytelling.

Throughout the text, it is evident that the author in her scientific approach analyzed and discussed a rich selection of reference literature from various theoretical scientific studies of the issue.

The monograph follows the principle of preparing a scientific monograph, its quality is also reflected in the already mentioned analysis and use of a large number of recent and foreign scientific literature and in the appropriate use of professionalscientific terminology. All together is meaningfully integrated and presented with findings and provisions for the Slovenian educational space.

I believe that the book will be very useful to all those involved in the use of educational technology, especially scientists, students, teachers in their analysis, planning and evaluation of the possibilities of using information and communication technologies in education. The book will also be a tool for counselors and decisionmakers in educational processes. Given the fact that the book is written in an international context using the English language, this will contribute to the additional and significant dissemination of the scientific monograph for wider international audience. 


\section{About the author}

Dr. Andreja Istenič, a full professor of didactics, has been examining and writing about educational technology and teacher education for 20 years. In 2002, after completing her doctoral studies, she joined the Faculty of Civil Engineering and Geodesy of the University of Ljubljana as the head for quality of teaching and learning in higher education. Since 2006 she has been a member in the e-construction research program. She teaches in the field of professional and career development and practical training for students. Since 2005 she also teaches in the Faculty of Education of the University of Primorska where she teaches educational technology, media education, The use of computers in the teaching of children with special needs, and learning environments for formal and non-formal adult learning. In the doctoral degree programmes, she teaches the compulsory subjects Contemporay findings of education science and Research seminar. She has also designed and teaches several elective courses in the field of educational technology at doctoral level - contemporary learning environments, information and communication technology in teaching and learning for participants with special needs, and educational technology to promote creativity in early learning. For her successful supervision of $\mathrm{PhD}$ students, she was among the finalists in the selection of a mentor of the year for 2019. This is awarded by the Young Academy Association in cooperation with the Slovene Research Agency. Andreja also mentors PhD students in Taiwan and US. She has been active on the editorial board of the British Journal of Educational Technology since 2010, until 2018 she was the editor for Europe, and in 2018 she was also the editor-in-chief of the journal. She participates in the editorial boards of several journals - Educational Technology Research and Development, British Journal of Educational Technology, Journal of Emerging Technologies and Learning, Education \& Self Development and others. In 2018, she was a visiting professor in the Department of Educational Technology at the University of North Texas where she taught the PhD course Extended Learning Environments. In 2012/13 she was a visiting researcher at Macquarie University in Sydney, where she carried out research in the creation of a personal learning environment for people with disabilities. Since 2017, she has been a visiting professor at the University of Kazan. She is an active member of the Association for Educational Communications and Technology 
(AECT) in the United States, and in 2018 she was a member of the organizing com mittee of a symposium on the future of learning, held at the University of North Texas. She is a member of the China Association for Educational Technology (SICET) and works with the University of Beijing, Zhejiang Univerity and universities in Taiwan. She is active in the European Organization for Educational Research (EERA) and the Association for Teacher Education in Europe (ATEE). She was a founding member of NW27 Didactics at EERA. She is also a member of the Slovenian Society for Research in Education (SLODRE) and the British Education Research Association (BERA). In recent years, she has been researching in the field of science evaluation in social sciences and humanities and is a member of EVALHUM - Research Evaluation, Innovation and Impact Analysis for the Social Sciences and Humanities. 


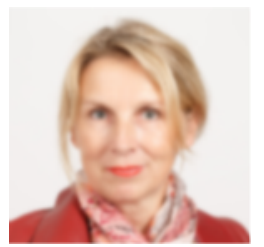

Dr. Andreja Istenič, a full professor of didactics, has been examining and writing about educational technology and teacher education for 20 years. In 2002, after completing her doctoral studies, she joined the Faculty of Civil Engineering and Geodesy of the University of Ljubljana as the head for quality of teaching and learning in higher education. Since 2006 she has been a member in the e-construction research program. She teaches in the field of professional and career development and practical training for students. Since 2005 she also teaches in the Faculty of Education of the University of Primorska where she teaches educational technology, media education, The use of computers in the teaching of children with special needs, and learning environments for formal and non-formal adult learning. In the doctoral degree programmes, she teaches the compulsory subjects contemporay findings of education science and Research seminar. She has also designed and teaches several elective courses in the field of educational technology at doctoral level - contemporary learning environments, information and communication technology in teaching and learning for participants with special needs, and educational technology to promote creativity in early learning. For her successful supervision of PhD students, she was among the finalists in the selection of a mentor of the year for 2019. This is awarded by the Young Academy Association in cooperation with the Slovene Research Agency. Andreja also mentors PhD students in Taiwan and US. She has been active on the editorial board of the British Journal of Educational Technology since 2010, until 2018 she was the editor for Europe, and in 2018 she was also the editor-in-chief of the journal. He participates in the editorial boards of several journals - Educational Technology Research and Development, British Journal of Educational Technology, Journal of Emerging Technologies and Learning and others. In 2018, she was a visiting professor in the Department of Educational Technology at the University of North Texas where she taught the PhD course Extended Learning Environments. In 2012/13 she was a visiting researcher at Macquarie University in Sydney, where she carried out research in the creation of a personal learning environment for people with disabilities. Since 2017, she has been a visiting professor at the University of Kazan. She is an active member of the Association for Educational Communications and Technology (AECT) in the United States, and in 2018 she was a member of the organizing committee of a symposium on the future of learning, held at the University of North Texas. She is a member of the China Association for Educational Technology (SICET) and works with the University of Beijing, Zhejiang Univerity and universities in Taiwan. She is active in the European Organization for Educational Research (EERA) and the Association for Teacher Education in Europe (ATEE). She was a founding member of NW27 Didactics at EERA. She is also a member of the Slovenian Society for Research in Education (SLODRE) and the British Education Research Association (BERA). In recent years, she has been researching in the field of science evaluation in social sciences and humanities and is a member of EVALHUM - Research Evaluation, Innovation and Impact Analysis for the Social Sciences and Humanities. 